\title{
Optimisation of Bee Pollen Extraction to Maximise Extractable Antioxidant Constituents
}

\author{
Ivan Lozada Lawag ${ }^{1,2} \mathbb{D}$, Okhee Yoo ${ }^{2}$, Lee Yong $\operatorname{Lim}^{2} \mathbb{( D}$, Katherine Hammer ${ }^{1,3}$ and Cornelia Locher ${ }^{1,2, *(\mathbb{D})}$ \\ 1 Cooperative Research Centre for Honey Bee Products Limited (CRC HBP), University of Western Australia, \\ Agriculture North M085, Perth, WA 6009, Australia; ivan.lawag@research.uwa.edu.au (I.L.L.); \\ katherine.hammer@uwa.edu.au (K.H.) \\ 2 Division of Pharmacy, School of Allied Health, University of Western Australia, Curnow Building M315, \\ Perth, WA 6009, Australia; okhee.yoo@research.uwa.edu.au (O.Y.); lee.lim@uwa.edu.au (L.Y.L.) \\ 3 M Block QEII Medical Centre, School of Biomedical Sciences, University of Western Australia, Monash Ave, \\ Perth, WA 6009, Australia \\ * Correspondence: Connie.Locher@uwa.edu.au
}

Citation: Lawag, I.L.; Yoo, O.; Lim,

L.Y.; Hammer, K.; Locher, C.

Optimisation of Bee Pollen Extraction to Maximise Extractable Antioxidant Constituents. Antioxidants 2021, 10, 1113. https://doi.org/10.3390/ antiox10071113

Academic Editor: Miguel Vilas-Boas

Received: 6 June 2021

Accepted: 7 July 2021

Published: 12 July 2021

Publisher's Note: MDPI stays neutral with regard to jurisdictional claims in published maps and institutional affiliations.

Copyright: (c) 2021 by the authors. Licensee MDPI, Basel, Switzerland. This article is an open access article distributed under the terms and conditions of the Creative Commons Attribution (CC BY) license (https:// creativecommons.org/licenses/by/ $4.0 /)$.

\begin{abstract}
This paper presents the findings of a comprehensive review on common bee pollen processing methods which can impact extraction efficiency and lead to differences in measured total phenolic content (TPC) and radical scavenging activity based on 2,2-diphenyl-1-picrylhydrazyl (DPPH) and ferric reducing antioxidant power (FRAP) data. This hampers the comparative analysis of bee pollen from different floral sources and geographical locations. Based on the review, an indepth investigation was carried out to identify the most efficient process to maximise the extraction of components for measurement of TPC, DPPH and FRAP antioxidant activity for two bee pollen samples from western Australia (Jarrah and Marri pollen). Optimisation by Design of Experiment with Multilevel Factorial Analysis (Categorical) modelling was performed. The independent variables included pollen pulverisation, the extraction solvent ( $70 \%$ aqueous ethanol, ethanol, methanol and water) and the extraction process (agitation, maceration, reflux and sonication). The data demonstrate that non-pulverised bee pollen extracted with $70 \%$ aqueous ethanol using the agitation extraction method constitute the optimal conditions to maximise the extraction of phenolics and antioxidant principles in these bee pollen samples.
\end{abstract}

Keywords: bee pollen; Jarrah; Marri; extraction; 2-diphenyl-1-picrylhydrazyl (DPPH); ferric reducing antioxidant power (FRAP); total phenolic content (TPC); optimisation; antioxidant activity; review; multilevel factor analysis (MFA)

\section{Introduction}

Flower pollen are the reproductive cells found in the stamen of plants which are transferred to the stigma of another plant via pollinating agents, such as bees, other insects, wind and water [1]. Bee pollen, on the other hand, is made by worker honeybees combining flower pollen, nectar and bee salivary constituents, and it is transferred to beehives in the form of pollen baskets attached to the bees' hind legs [1,2]. Inside the hives, bee pollen is packed into honeycomb cells and covered with a layer of honey and wax to initiate fermentation to generate bee bread, which is the principal source of nutrients for honeybees [2]. Bee pollen, which is also known as apicultural, bee-collected or corbicular pollen, can be harvested for human consumption with the help of pollen traps. These traps are fixed at the entrance of beehives and collect pollen by stripping the pollen baskets from the hind legs of bees on entry to the hives [3].

Bee pollen provides bees with carbohydrates and other necessary nutrients such as proteins, fats, minerals and vitamins [4]. The secondary metabolite profiles of bee pollens vary significantly, reflecting the botanical and geographical origin as well as the climatic conditions, soil type and beekeeper activities [5,6]. The chemical composition of 
bee pollens typically includes $13-55 \%$ carbohydrates, $10-40 \%$ proteins and $1-13 \%$ lipids, alongside minor components such as minerals and trace elements, vitamins, carotenoids, phenolic compounds, flavonoids, sterols and terpenes [6-8]. Some even consider bee pollen to be the only complete food, as it contains all the essential amino acids needed by humans [6]. Bee pollen has been recommended as a natural nutraceutical due to its antimicrobial, antioxidant, anti-inflammatory, antiallergen, anticarcinogenic, antiradiation, antiulcer, hepatoprotective and chemopreventive properties. More recently, bee pollen has been found to modulate gut microbiota to promote gut health [6-8].

The antioxidant activity of bee pollen is mainly associated with the presence of polyphenols in the form of phenolic acids and flavonoids, which exert their antioxidant activity by neutralising free radicals through the donation of electron or hydrogen atoms [9]. This bioactivity has attracted considerable interest in recent years because of its association with anti-inflammatory, anti-cancer and also anti-aging effects [5]. Commonly, the determination of the antioxidant activity of honey and other bee products such as bee pollen involves the use of a range of popular colorimetric assays. These include the measurement of total phenolic content (TPC) [10-14], total flavonoid content (TFC) [13-15], free radical scavenging activity using the 2,2-diphenyl-1-picrylhydrazyl (DPPH) assay [4,12-16] or measuring the ferric reducing antioxidant power (FRAP) $[4,10,17]$. DPPH and FRAP assays, in particular, are widely used to determine the antioxidant activity of plant extracts and food products. These assays use stable redox reagents which are inexpensive and easy to prepare, they are quick and easy to perform, and the results are accurate, highly reproducible, and readily validated [18].

The determination of the antioxidant activity of bee pollen necessitates an extraction step guided by the premise of a high yield and minimal changes to the functional properties of the extract. It is, therefore, necessary to select an appropriate extraction method and solvent, based on sample matrix properties, the chemical properties of the analytes as well as potential matrix-analyte interactions [19]. Further parameters that require consideration are the number of extractions to be performed, the extraction time, the ratio of solvent to raw material, and the extraction pressure and temperature. As the polarity of bioactive polyphenols ranges from very polar to relatively non-polar, the extraction solvent plays a significant role in extraction efficiency [20]. Furthermore, pre-extraction processes such as pulverisation can also affect the extraction efficiency of bioactive principles, as powdered samples have smaller particle sizes and narrower particle size distribution, leading to improved surface contact with extraction solvents [21].

In order to determine an optimal extraction process for bee pollen that yields the maximum extraction of antioxidant constituents, a survey of the literature was carried out. A review of 101 papers published between 2003 and 2021 reporting the antioxidant activity of bee pollen found a wide range of extraction conditions (Table 1). Some, but not all, subjected the samples to pulverisation (31.7\%). Extraction solvents also varied, though they were mainly of high polarity, with methanol (21.8\%), 70\% aqueous ethanol (13.0\%), ethanol $(10.1 \%)$ and water $(10.1 \%)$ being the more commonly used solvents. As for the extraction process itself, maceration was found to be most widely used (34.8\%), followed by sonication $(26.1 \%)$, agitation $(23.1 \%)$ and reflux extraction $(1.5 \%)$. 
Table 1. Summary of extraction parameters used to determine the antioxidant activity of bee pollen.

\begin{tabular}{|c|c|c|c|c|c|c|c|c|c|c|c|c|c|c|}
\hline Author & Reference & Country & $\begin{array}{c}\text { Botanical } \\
\text { Origin }\end{array}$ & $\begin{array}{c}\text { Pre- } \\
\text { Extraction }\end{array}$ & $\begin{array}{c}\text { Pulve- } \\
\text { Risation }\end{array}$ & $\begin{array}{l}\text { Extraction } \\
\text { Method }\end{array}$ & Solvent & $\begin{array}{c}\text { Volume } \\
\text { of } \\
\text { Solvent }\end{array}$ & $\begin{array}{c}\text { Extraction } \\
\text { Tempe- } \\
\text { Rature }\end{array}$ & $\begin{array}{l}\text { Mixing/ } \\
\text { Power }\end{array}$ & $\begin{array}{c}\text { Extraction } \\
\text { Time }\end{array}$ & $\begin{array}{l}\text { No. of } \\
\text { Extrac- } \\
\text { tions }\end{array}$ & $\begin{array}{c}\text { Post- } \\
\text { Extraction }\end{array}$ & $\begin{array}{l}\text { Antioxidant } \\
\text { Assays }\end{array}$ \\
\hline $\begin{array}{c}\text { Daoud, } \\
\text { Ibrahim } \\
\text { et al., } 2019\end{array}$ & [22] & Algeria & Inula viscosa & $\begin{array}{l}\text { Stored at } \\
4{ }^{\circ} \mathrm{C}\end{array}$ & None & Maceration & $\begin{array}{c}80 \% \\
\text { Methanol } \\
\text { (Aqueous) }\end{array}$ & $\begin{array}{l}10 \mathrm{~g} \mathrm{w} / \\
100 \mathrm{~mL}\end{array}$ & N.I. & N.I. & $24 \mathrm{~h}$ & 2 & $\begin{array}{l}\text { Dried in } \\
\text { vacuo }\end{array}$ & $\begin{array}{l}\text { TPC, TFC, } \\
\beta \text {-carotene } \\
\text { bleaching }\end{array}$ \\
\hline $\begin{array}{l}\text { Machado } \\
\text { De-Melo, } \\
\text { Estevinho } \\
\text { et al., } 2016\end{array}$ & [23] & Brazil & multifloral & $\begin{array}{c}\text { Stored at } \\
-20^{\circ} \mathrm{C}, \\
\text { some } \\
\text { batches } \\
\text { were oven } \\
\text { dried at } \\
42^{\circ} \mathrm{C}, \\
\text { another was } \\
\text { vacuum } \\
\text { lyophilised }\end{array}$ & $\begin{array}{c}\text { Crushed } \\
\text { and } \\
\text { sieved } \\
\text { through } \\
\text { a } 0.595 \\
\mathrm{~mm} \\
\text { sieve }\end{array}$ & Agitation & $\begin{array}{c}70 \% \\
\text { Ethanol } \\
\text { (Aqueous) }\end{array}$ & $\begin{array}{l}2 \mathrm{~g} \mathrm{w} / \\
25 \mathrm{~mL}\end{array}$ & $70^{\circ} \mathrm{C}$ & $105 \mathrm{rpm}$ & $30 \mathrm{~min}$ & N.I. & $\begin{array}{l}\text { Volume } \\
\text { was } \\
\text { adjusted } \\
\text { to } 25 \mathrm{~mL}\end{array}$ & $\begin{array}{l}\text { TPC, DPPH, } \\
\text { ORAC }\end{array}$ \\
\hline $\begin{array}{l}\text { Kalaycioğlu, } \\
\text { Kaygusuz } \\
\text { et al., } 2017\end{array}$ & [7] & Turkey & $\begin{array}{c}\text { Chestnuts, } \\
\text { Buckwheat, } \\
\text { Oak, } \\
\text { multifloral }\end{array}$ & N.I. & $\begin{array}{c}\text { Ground } \\
\text { in } \\
\text { mortar } \\
\text { and } \\
\text { pestle }\end{array}$ & Maceration & Water & $\begin{array}{c}0.1 \mathrm{~g} \mathrm{w} / \\
5 \mathrm{~mL}\end{array}$ & $80^{\circ} \mathrm{C}$ & None & $15 \mathrm{~min}$ & N.I. & $\begin{array}{c}\text { Filtered } \\
\text { using } \\
\text { Whatman } \\
\# 41\end{array}$ & TPC, DPPH \\
\hline $\begin{array}{l}\text { Alimoglu, } \\
\text { Guzelmeric } \\
\text { et al., } 2021\end{array}$ & [24] & Turkey & multifloral & $\begin{array}{l}\text { Stored at } \\
20^{\circ} \mathrm{C}\end{array}$ & None & $\begin{array}{l}\text { Agitation } \\
\text { and } \\
\text { Sonication }\end{array}$ & $\begin{array}{c}70 \% \\
\text { Ethanol } \\
\text { (Aqueous) }\end{array}$ & $\begin{array}{l}5 \mathrm{~g} \mathrm{w} / \\
50 \mathrm{~mL}\end{array}$ & $40^{\circ} \mathrm{C}$ & $\begin{array}{l}100 \mathrm{rpm}, \\
\text { N.I. }\end{array}$ & $\begin{array}{l}1 \mathrm{~h} \text { and } \\
15 \mathrm{~min}\end{array}$ & N.I. & $\begin{array}{c}\text { Filtered } \\
\text { using } \\
\text { filter } \\
\text { paper, } \\
\text { dried in } \\
\text { vacuo }\end{array}$ & $\begin{array}{c}\text { TPC, TFC, } \\
\text { DPPH, } \\
\text { CUPRAC, } \\
\text { FRAP }\end{array}$ \\
\hline $\begin{array}{l}\text { Pascoal, } \\
\text { Rodrigues } \\
\text { et al., } 2014\end{array}$ & [25] & $\begin{array}{l}\text { Porugal } \\
\text { and } \\
\text { Spain }\end{array}$ & multifloral & $\begin{array}{l}\text { Stored at } \\
20^{\circ} \mathrm{C}\end{array}$ & None & Maceration & Methanol & $1: 2 w / v$ & RT & None & $72 \mathrm{~h}$ & 2 & $\begin{array}{c}\text { Filtered } \\
\text { using } \\
\text { Whatman } \\
\text { \#4, dried } \\
\text { in vacuo, }\end{array}$ & $\begin{array}{c}\text { TPC, TFC, } \\
\text { TBARS, } \\
\text { DPPH }\end{array}$ \\
\hline $\begin{array}{c}\text { Morais, } \\
\text { Moreira } \\
\text { et al., } 2011\end{array}$ & [26] & Portugal & multifloral & $\begin{array}{l}\text { Stored at } \\
-20^{\circ} \mathrm{C}\end{array}$ & None & Maceration & Methanol & $1: 2 w / v$ & RT & None & $72 \mathrm{~h}$ & 2 & N.I. & $\begin{array}{c}\text { TPC, DPPH, } \\
\beta \text {-carotene } \\
\text { bleaching }\end{array}$ \\
\hline $\begin{array}{c}\text { Leja, } \\
\text { Mareczek } \\
\text { et al., } 2006\end{array}$ & [27] & Poland & multifloral & $\begin{array}{l}\text { Stored at } \\
-18^{\circ} \mathrm{C}\end{array}$ & None & Maceration & $\begin{array}{c}80 \% \\
\text { Methanol } \\
\text { (Aqueous) }\end{array}$ & N.I. & N.I. & None & N.I. & N.I. & N.I. & $\begin{array}{c}\text { TPC, TFC, } \\
\text { anthocyani- } \\
\text { dins, } \\
\text { phenyl- } \\
\text { propanoids, } \\
\text { DPPH, TAA }\end{array}$ \\
\hline
\end{tabular}


Table 1. Cont.

\begin{tabular}{|c|c|c|c|c|c|c|c|c|c|c|c|c|c|c|}
\hline Author & Reference & Country & $\begin{array}{c}\text { Botanical } \\
\text { Origin }\end{array}$ & $\begin{array}{c}\text { Pre- } \\
\text { Extraction }\end{array}$ & $\begin{array}{c}\text { Pulve- } \\
\text { Risation }\end{array}$ & $\begin{array}{l}\text { Extraction } \\
\text { Method }\end{array}$ & Solvent & $\begin{array}{l}\begin{array}{c}\text { Volume } \\
\text { of } \\
\text { Solvent }\end{array} \\
\end{array}$ & $\begin{array}{c}\text { Extraction } \\
\text { Tempe- } \\
\text { Rature }\end{array}$ & $\begin{array}{c}\text { Mixing/ } \\
\text { Power }\end{array}$ & $\begin{array}{c}\text { Extraction } \\
\text { Time }\end{array}$ & $\begin{array}{l}\text { No. of } \\
\text { Extrac- } \\
\text { tions }\end{array}$ & $\begin{array}{c}\text { Post- } \\
\text { Extraction }\end{array}$ & $\begin{array}{l}\text { Antioxidant } \\
\text { Assays }\end{array}$ \\
\hline $\begin{array}{l}\text { Mărghitaş, } \\
\text { Stanciu } \\
\text { et al., } 2009\end{array}$ & [28] & Romania & multifloral & N.I. & None & $\begin{array}{l}\text { Maceration } \\
\text { and } \\
\text { Sonication }\end{array}$ & Methanol & $\begin{array}{l}2 \mathrm{gw} / \\
15 \mathrm{~mL}\end{array}$ & RT & None & $\begin{array}{l}1 \mathrm{~h} \text { and } \\
15 \mathrm{~min}\end{array}$ & 3 & $\begin{array}{l}\text { Dried in } \\
\text { vacuo }\end{array}$ & $\begin{array}{c}\text { TPC, TFC, } \\
\text { DPPH, } \\
\text { FRAP, ABTS }\end{array}$ \\
\hline $\begin{array}{l}\text { Thakur } \\
\text { and } \\
\text { Nanda } \\
2021\end{array}$ & [29] & India & $\begin{array}{l}\text { Coconut, } \\
\text { Coriander, } \\
\text { Rapeseed, } \\
\text { and } \\
\text { multifloral }\end{array}$ & $\begin{array}{l}\text { Stored at } \\
-18^{\circ} \mathrm{C}\end{array}$ & $\begin{array}{l}\text { Ground } \\
\text { (method } \\
\text { not indi- } \\
\text { cated) }\end{array}$ & $\begin{array}{l}\text { Maceration } \\
\text { and } \\
\text { Sonication }\end{array}$ & $\begin{array}{c}85 \% \\
\text { Methanol } \\
\text { (Aqueous) }\end{array}$ & $0.15: 1$ & RT & None & $\begin{array}{l}2 \mathrm{~h} \text { and } \\
30 \mathrm{~min}\end{array}$ & N.I. & $\begin{array}{l}\text { Centrifuged, } \\
\text { and Dried } \\
\text { in vacuo, }\end{array}$ & $\begin{array}{c}\text { TPC, TFC, } \\
\text { DPPH, } \\
\text { FRAP, } \\
\text { ABTS, } \\
\text { MCA, }\end{array}$ \\
\hline $\begin{array}{l}\text { Machado } \\
\text { De-Melo, } \\
\text { Estevinho } \\
\text { et al., } 2018\end{array}$ & [30] & Brazil & $\begin{array}{c}\text { Mimosa } \\
\text { caesalpiniifolia, } \\
\text { Eucalyptus } \\
\text { spp., } \\
\text { Rubiaceae, } \\
\text { Astrocaryum } \\
\text { aculeatissimum, } \\
\text { Fabaceae, } \\
\text { Cocos nucifera, } \\
\text { M. verrucosa, } \\
\text { Myrcia spp., } \\
\text { Alternanthera } \\
\text { spp., } \\
\text { Asteraceae, } \\
\text { Brassica spp., } \\
\text { and } \\
\text { multifloral }\end{array}$ & $\begin{array}{l}\text { Stored at } \\
-4{ }^{\circ} \mathrm{C}\end{array}$ & None & Maceration & Methanol & $1: 2 w / v$ & RT & None & $72 \mathrm{~h}$ & 2 & N.I. & $\begin{array}{c}\text { TPC, TFC, } \\
\text { DPPH, } \\
\text { ORAC }\end{array}$ \\
\hline $\begin{array}{l}\text { Machado } \\
\text { De-Melo, } \\
\text { Estevinho } \\
\text { et al., } 2018\end{array}$ & [30] & Brazil & $\begin{array}{c}\text { Mimosa } \\
\text { caesalpiniifolia, } \\
\text { Eucalyptus } \\
\text { spp., } \\
\text { Rubiaceae, } \\
\text { Astrocaryum } \\
\text { aculeatissimum, } \\
\text { Fabaceae, } \\
\text { Cocos nucifera, } \\
\text { M. verrucosa, } \\
\text { Myrcia spp., } \\
\text { Alternanthera } \\
\text { spp., } \\
\text { Asteraceae, } \\
\text { Brassica spp. } \\
\text { and } \\
\text { multifloral }\end{array}$ & $\begin{array}{l}\text { Stored at } \\
-4^{\circ} \mathrm{C}\end{array}$ & None & Agitation & $\begin{array}{c}70 \% \\
\text { Ethanol } \\
\text { (Aqueous) }\end{array}$ & $2 \mathrm{~g} / 25 \mathrm{~mL}$ & $70^{\circ} \mathrm{C}$ & $105 \mathrm{rpm}$ & $30 \mathrm{~min}$ & N.I. & N.I. & $\begin{array}{c}\text { TPC, TFC, } \\
\text { DPPH, } \\
\text { ORAC }\end{array}$ \\
\hline
\end{tabular}


Table 1. Cont.

\begin{tabular}{|c|c|c|c|c|c|c|c|c|c|c|c|c|c|c|}
\hline Author & Reference & Country & $\begin{array}{c}\text { Botanical } \\
\text { Origin }\end{array}$ & $\begin{array}{c}\text { Pre- } \\
\text { Extraction }\end{array}$ & $\begin{array}{c}\text { Pulve- } \\
\text { Risation }\end{array}$ & $\begin{array}{l}\text { Extraction } \\
\text { Method }\end{array}$ & Solvent & $\begin{array}{c}\begin{array}{c}\text { Volume } \\
\text { of } \\
\text { Solvent }\end{array} \\
\text {. }\end{array}$ & $\begin{array}{c}\text { Extraction } \\
\text { Tempe- } \\
\text { Rature }\end{array}$ & $\begin{array}{l}\text { Mixing/ } \\
\text { Power }\end{array}$ & $\begin{array}{l}\text { Extraction } \\
\text { Time }\end{array}$ & $\begin{array}{l}\text { No. of } \\
\text { Extrac- } \\
\text { tions }\end{array}$ & $\begin{array}{c}\text { Post- } \\
\text { Extraction }\end{array}$ & $\begin{array}{l}\text { Antioxidant } \\
\text { Assays }\end{array}$ \\
\hline $\begin{array}{l}\text { Kaškonienè, } \\
\text { Adaške- } \\
\text { vičiūtè } \\
\text { et al., } 2020\end{array}$ & [31] & $\begin{array}{l}\text { Latvia } \\
\text { and } \\
\text { Lithua- } \\
\text { nia }\end{array}$ & multifloral & $\begin{array}{l}\text { Pasteurisation } \\
\text { at } 95^{\circ} \mathrm{C} \text { for } \\
20 \text { min and } \\
\text { stored at } \\
6-8^{\circ} \mathrm{C}\end{array}$ & None & Agitation & $\begin{array}{c}80 \% \\
\text { Methanol } \\
\text { (Aqueous) }\end{array}$ & $\begin{array}{c}2 \mathrm{~g} / \\
20 \mathrm{~mL}\end{array}$ & RT & $180 \mathrm{rpm}$ & N.I. & N.I. & $\begin{array}{c}\text { 7-10 } \mu \mathrm{m} \\
\text { paper } \\
\text { filter } \\
\text { (Labbox), } \\
\text { followed } \\
\text { by a } 0.22 \\
\mu \mathrm{m} \\
\text { polyvinyli- } \\
\text { dene } \\
\text { fluoride } \\
\text { (PVDF) } \\
\text { mem- } \\
\text { brane } \\
\text { filter, } \\
\text { stored at } 4 \\
\text { C. }\end{array}$ & $\begin{array}{c}\text { TPC, TFC, } \\
\text { DPPH }\end{array}$ \\
\hline $\begin{array}{c}\text { Wan } \\
\text { Omar, } \\
\text { Azhar } \\
\text { et al., } 2016 \\
\end{array}$ & [32] & Malaysia & L. terminate & N.I. & None & Sonication & Methanol & $\begin{array}{l}10 \mathrm{~g} / \\
25 \mathrm{~mL}\end{array}$ & $41^{\circ} \mathrm{C}$ & N.I. & $1 \mathrm{~h}$ & N.I. & $\begin{array}{l}\text { Centrifuged, } \\
\text { filtered } \\
\text { using } 0.2 \\
\text { mm filter }\end{array}$ & DPPH \\
\hline $\begin{array}{l}\text { Zhang, } \\
\text { Wang } \\
\text { et al., } 2015\end{array}$ & [34] & China & $\begin{array}{l}\text { Rape (Brassica } \\
\text { campestris L.) }\end{array}$ & $\begin{array}{c}\text { Vacuum } \\
\text { dried at } \\
50^{\circ} \mathrm{C} \text { and } \\
\text { stored at } \\
-18^{\circ} \mathrm{C}\end{array}$ & $\begin{array}{l}\text { Ground } \\
\text { (method } \\
\text { not indi- } \\
\text { cated) }\end{array}$ & Maceration & Water & $\begin{array}{l}1: 20 \\
w / v\end{array}$ & RT & None & $24 \mathrm{~h}$ & N.I. & $\begin{array}{l}\text { Centrifuged, } \\
\text { reconsti- } \\
\text { tuted to } \\
100 \mathrm{~mL}\end{array}$ & $\begin{array}{c}\text { TPC, TFC, } \\
\text { ABTS, } \\
\text { DPPH, } \\
\text { Reducing } \\
\text { power }\end{array}$ \\
\hline $\begin{array}{l}\text { Zhang, } \\
\text { Wang } \\
\text { et al., } 2015\end{array}$ & [34] & China & $\begin{array}{l}\text { Rape (Brassica } \\
\text { campestris L.) }\end{array}$ & $\begin{array}{c}\text { Rape } \\
\text { (Brassica } \\
\text { campestris } \\
\text { L.) }\end{array}$ & $\begin{array}{l}\text { Ground } \\
\text { (method } \\
\text { not indi- } \\
\text { cated) }\end{array}$ & Maceration & $\begin{array}{c}25 \% \\
\text { Ethanol } \\
\text { (Aqueous) }\end{array}$ & $\begin{array}{l}1: 20 \\
w / v\end{array}$ & RT & None & $24 \mathrm{~h}$ & N.I. & $\begin{array}{l}\text { Centrifuged, } \\
\text { reconsti- } \\
\text { tuted to } \\
100 \mathrm{~mL}\end{array}$ & $\begin{array}{c}\text { TPC, TFC, } \\
\text { ABTS, } \\
\text { DPPH, } \\
\text { Reducing } \\
\text { power }\end{array}$ \\
\hline $\begin{array}{l}\text { Zhang, } \\
\text { Wang, } \\
\text { et al., } 2015\end{array}$ & [34] & China & $\begin{array}{l}\text { Rape (Brassica } \\
\text { campestris L.) }\end{array}$ & $\begin{array}{c}\text { Vacuum } \\
\text { dried at } \\
50^{\circ} \mathrm{C} \text { and } \\
\text { stored at } \\
-18^{\circ} \mathrm{C}\end{array}$ & $\begin{array}{l}\text { Ground } \\
\text { (method } \\
\text { not indi- } \\
\text { cated) }\end{array}$ & Maceration & $\begin{array}{c}50 \% \\
\text { Ethanol } \\
\text { (Aqueous) }\end{array}$ & $\begin{array}{l}1: 20 \\
w / v\end{array}$ & RT & None & $24 \mathrm{~h}$ & N.I. & $\begin{array}{l}\text { Centrifuged, } \\
\text { reconsti- } \\
\text { tuted to } \\
100 \mathrm{~mL}\end{array}$ & $\begin{array}{c}\text { TPC, TFC, } \\
\text { ABTS, } \\
\text { DPPH, } \\
\text { Reducing } \\
\text { power }\end{array}$ \\
\hline
\end{tabular}


Table 1. Cont.

\begin{tabular}{|c|c|c|c|c|c|c|c|c|c|c|c|c|c|c|}
\hline Author & Reference & Country & $\begin{array}{c}\text { Botanical } \\
\text { Origin }\end{array}$ & $\begin{array}{c}\text { Pre- } \\
\text { Extraction }\end{array}$ & $\begin{array}{c}\text { Pulve- } \\
\text { Risation }\end{array}$ & $\begin{array}{l}\text { Extraction } \\
\text { Method }\end{array}$ & Solvent & $\begin{array}{l}\text { Volume } \\
\text { of } \\
\text { Solvent }\end{array}$ & $\begin{array}{c}\text { Extraction } \\
\text { Tempe- } \\
\text { Rature }\end{array}$ & $\begin{array}{l}\text { Mixing/ } \\
\text { Power }\end{array}$ & $\begin{array}{l}\text { Extraction } \\
\text { Time }\end{array}$ & $\begin{array}{l}\text { No. of } \\
\text { Extrac- } \\
\text { tions }\end{array}$ & $\begin{array}{c}\text { Post- } \\
\text { Extraction }\end{array}$ & $\begin{array}{l}\text { Antioxidant } \\
\text { Assays }\end{array}$ \\
\hline $\begin{array}{l}\text { Zhang, } \\
\text { Wang } \\
\text { et al., } 2015\end{array}$ & [34] & China & $\begin{array}{l}\text { Rape (Brassica } \\
\text { campestris L.) }\end{array}$ & $\begin{array}{c}\text { Vacuum } \\
\text { dried at } \\
50^{\circ} \mathrm{C} \text { and } \\
\text { stored at } \\
-18^{\circ} \mathrm{C}\end{array}$ & $\begin{array}{l}\text { Ground } \\
\text { (method } \\
\text { not indi- } \\
\text { cated) }\end{array}$ & Maceration & $\begin{array}{c}75 \% \\
\text { Ethanol } \\
\text { (Aqueous) }\end{array}$ & $\begin{array}{l}1: 20 \\
w / v\end{array}$ & RT & None & $24 \mathrm{~h}$ & N.I. & $\begin{array}{l}\text { Centrifuged, } \\
\text { reconsti- } \\
\text { tuted to } \\
100 \mathrm{~mL}\end{array}$ & $\begin{array}{c}\text { TPC, TFC, } \\
\text { ABTS, } \\
\text { DPPH, } \\
\text { Reducing } \\
\text { power }\end{array}$ \\
\hline $\begin{array}{l}\text { Zhang, } \\
\text { Wang, } \\
\text { et al., } 2015\end{array}$ & [34] & China & $\begin{array}{l}\text { Rape (Brassica } \\
\text { campestris L.) }\end{array}$ & $\begin{array}{c}\text { Vacuum } \\
\text { dried at } \\
50^{\circ} \mathrm{C} \text { and } \\
\text { stored at } \\
-18^{\circ} \mathrm{C}\end{array}$ & $\begin{array}{l}\text { Ground } \\
\text { (method } \\
\text { not indi- } \\
\text { cated) }\end{array}$ & Maceration & Ethanol & $\begin{array}{l}1: 20 \\
w / v\end{array}$ & RT & None & $24 \mathrm{~h}$ & N.I. & $\begin{array}{l}\text { Centrifuged, } \\
\text { reconsti- } \\
\text { tuted to } \\
100 \mathrm{~mL}\end{array}$ & $\begin{array}{c}\text { TPC, TFC, } \\
\text { ABTS, } \\
\text { DPPH, } \\
\text { Reducing } \\
\text { power }\end{array}$ \\
\hline $\begin{array}{l}\text { Hemmami, } \\
\text { Ben } \\
\text { Seghir } \\
\text { et al., } 2020\end{array}$ & [35] & Algeria & multifloral & N.I. & $\begin{array}{l}\text { Crushed } \\
\text { in a } \\
\text { commer- } \\
\text { cial } \\
\text { blender } \\
\text { and ho- } \\
\text { mogenised. }\end{array}$ & Sonication & Methanol & $\begin{array}{c}0.2 \mathrm{~g} \mathrm{w} / \\
2 \mathrm{~mL}\end{array}$ & RT & N.I. & $30 \mathrm{~min}$ & N.I. & $\begin{array}{l}\text { Centrifuged, } \\
\text { filtered } \\
\text { using } \\
\text { Whatman } \\
\text { \# 1, dried } \\
\text { in vacuo, } \\
\text { stored in } \\
4^{\circ} \mathrm{C} \text { in } \\
\text { brown } \\
\text { bottle }\end{array}$ & $\begin{array}{c}\text { TPC, TFC, } \\
\text { TAC }\end{array}$ \\
\hline $\begin{array}{l}\text { Zuluaga- } \\
\text { Domínguez, } \\
\text { Serrato- } \\
\text { Bermudez } \\
\text { et al., } 2018\end{array}$ & [37] & Colombia & $\begin{array}{l}\text { Hypochaeris } \\
\text { radicata } \\
\text { and Brassica } \\
\text { sp. }\end{array}$ & $\begin{array}{l}\text { Stored at } \\
2{ }^{\circ} \mathrm{C}\end{array}$ & None & Maceration & $\begin{array}{c}96 \% \\
\text { Ethanol } \\
\text { (Aqueous) }\end{array}$ & $\begin{array}{l}1 \mathrm{~g} \mathrm{w} / \\
30 \mathrm{~mL}\end{array}$ & N.I. & N.I. & $24 \mathrm{~h}$ & N.I. & $\begin{array}{c}\text { Filtered } \\
\text { using } 3 \\
\text { hw filter } \\
\text { paper and } \\
\text { reconsti- } \\
\text { tuted to } \\
100 \mathrm{~mL}\end{array}$ & $\begin{array}{c}\text { TPC, TFC, } \\
\text { ABTS, } \\
\text { FRAP }\end{array}$ \\
\hline $\begin{array}{c}\text { Keskin } \\
\text { and } \\
\text { Özkök } \\
2020\end{array}$ & [38] & Turkey & multifloral & $\begin{array}{c}\text { Dried at } \\
\text { different } \\
\text { conditions }\end{array}$ & None & Agitation & Ethanol & $\begin{array}{c}3 \mathrm{~g} / \\
20 \mathrm{~mL}\end{array}$ & N.I. & N.I. & $12 \mathrm{~h}$ & N.I. & $\begin{array}{l}\text { Filtered } \\
\text { and the } \\
\text { final } \\
\text { volume } \\
\text { was com- } \\
\text { pleted to } \\
30 \mathrm{~mL}\end{array}$ & TPC \\
\hline
\end{tabular}


Table 1. Cont.

\begin{tabular}{|c|c|c|c|c|c|c|c|c|c|c|c|c|c|c|}
\hline Author & Reference & Country & $\begin{array}{c}\text { Botanical } \\
\text { Origin }\end{array}$ & $\begin{array}{c}\text { Pre- } \\
\text { Extraction }\end{array}$ & $\begin{array}{c}\text { Pulve- } \\
\text { Risation }\end{array}$ & $\begin{array}{l}\text { Extraction } \\
\text { Method }\end{array}$ & Solvent & $\begin{array}{l}\text { Volume } \\
\text { of } \\
\text { Solvent }\end{array}$ & $\begin{array}{l}\text { Extraction } \\
\text { Tempe- } \\
\text { Rature } \\
\end{array}$ & $\underset{\text { Power }}{\text { Mixing/ }}$ & $\begin{array}{l}\text { Extraction } \\
\text { Time }\end{array}$ & $\begin{array}{l}\text { No. of } \\
\text { Extrac- } \\
\text { tions }\end{array}$ & $\begin{array}{c}\text { Post- } \\
\text { Extraction }\end{array}$ & $\begin{array}{l}\text { Antioxidant } \\
\text { Assays }\end{array}$ \\
\hline $\begin{array}{l}\text { Vasconcelos, } \\
\text { Duarte } \\
\text { et al., } 2017\end{array}$ & [39] & Brazil & multifloral & N.I. & None & Agitation & $\begin{array}{c}70 \% \\
\text { Ethanol } \\
\text { (Aqueous) }\end{array}$ & $1 \mathrm{~g} / 10 \mathrm{~mL}$ & $70{ }^{\circ} \mathrm{C}$ & $150 \mathrm{rpm}$ & $30 \mathrm{~min}$ & 2 & Centrifuged & $\begin{array}{l}\text { TPC, TFC, } \\
\text { DPPH, } \\
\text { FRAP }\end{array}$ \\
\hline $\begin{array}{l}\text { Suriyatem, } \\
\text { Auras } \\
\text { et al., } 2017\end{array}$ & [40] & Thailand & Longan & $\begin{array}{l}\text { Stored at } \\
20^{\circ} \mathrm{C}\end{array}$ & None & Maceration & Methanol & $\begin{array}{c}1: 2 \\
(w / v) .\end{array}$ & RT & $\begin{array}{l}\text { Shaken } \\
\text { by hand } \\
\text { twice a } \\
\text { day }\end{array}$ & $72 \mathrm{~h}$ & 2 & $\begin{array}{l}\text { Filtered } \\
\text { using } \\
\text { Whatman } \\
\# 4 \text { and } \\
\text { dried in } \\
\text { vacuo }\end{array}$ & $\begin{array}{c}\text { TPC, DPPH, } \\
\text { ABTS }\end{array}$ \\
\hline $\begin{array}{l}\text { Cosmulescu, } \\
\text { Trandafir } \\
\text { et al., } 2015\end{array}$ & [41] & Romania & $\begin{array}{c}\text { Walnut } \\
\text { (Juglans regia } \\
\text { L.) }\end{array}$ & N.I. & None & $\begin{array}{l}\text { Sonication } \\
\text { and } \\
\text { maceration }\end{array}$ & Methanol & $1 \mathrm{~g} / 10 \mathrm{~mL}$ & RT & N.I. & $\begin{array}{l}60 \mathrm{~min} \\
\text { and } 24 \mathrm{~h}\end{array}$ & 1 & $\begin{array}{l}\text { Filtered } \\
\text { using } 0.45 \\
\mu \text { m mem- } \\
\text { brane } \\
\text { filter }\end{array}$ & $\begin{array}{l}\text { TPC, TFC, } \\
\text { DPPH }\end{array}$ \\
\hline $\begin{array}{l}\text { Bridi, } \\
\text { Atala } \\
\text { et al., } 2019\end{array}$ & [42] & Chile & $\begin{array}{c}\text { Brassica rapa } \\
\text { and } \\
\text { Eschscholzia } \\
\text { californica }\end{array}$ & $\begin{array}{l}\text { Stored at } \\
-20^{\circ} \mathrm{C}\end{array}$ & None & Sonication & Ethanol & $1 \mathrm{~g} / 10 \mathrm{~mL}$ & $-20^{\circ} \mathrm{C}$ & N.I. & $10 \mathrm{~min}$ & 3 & $\begin{array}{l}\text { Centrifuged } \\
\text { and } \\
\text { filtered } \\
\text { using } \\
\text { Whatman } \\
\text { No.1 and } \\
\text { reconsti- } \\
\text { tuted to } \\
50 \mathrm{~mL}\end{array}$ & $\begin{array}{c}\text { TPC, TFC, } \\
\text { FRAP, } \\
\text { ORAC }\end{array}$ \\
\hline $\begin{array}{l}\text { Lopes, } \\
\text { Vasconce- } \\
\text { los et al., } \\
2019\end{array}$ & [43] & Brazil & multifloral & $\begin{array}{l}\text { Stored at } \\
44^{\circ} \mathrm{C}\end{array}$ & None & Maceration & $\begin{array}{c}70 \% \\
\text { Ethanol } \\
\text { (Aqueous) }\end{array}$ & $\begin{array}{c}1: 5 \\
(m / v)\end{array}$ & RT & None & $\begin{array}{c}72 \mathrm{~h} \\
\text { (solvent } \\
\text { renewal } \\
\text { every } \\
24 \mathrm{~h} \text { ) } \\
\end{array}$ & 3 & $\begin{array}{l}\text { Dried in } \\
\text { vacuo }\end{array}$ & $\begin{array}{c}\text { TPC, TFC, } \\
\text { FRAP, } \\
\text { DPPH, } \\
\text { ABTS }\end{array}$ \\
\hline $\begin{array}{l}\text { Lopes, } \\
\text { Vasconce- } \\
\text { los et al., } \\
2020\end{array}$ & [44] & Brazil & multifloral & $\begin{array}{l}\text { Stored at } \\
44^{\circ} \mathrm{C}\end{array}$ & None & Maceration & $\begin{array}{c}70 \% \\
\text { Ethanol } \\
\text { (Aqueous) }\end{array}$ & $\begin{array}{c}1: 5 \\
(m / v)\end{array}$ & RT & None & $\begin{array}{l}72 \mathrm{~h} \\
\text { (solvent } \\
\text { renewal } \\
\text { every } \\
24 \mathrm{~h} \text { ) }\end{array}$ & 3 & $\begin{array}{l}\text { Dried in } \\
\text { vacuo, } \\
\text { lyophilised }\end{array}$ & $\begin{array}{c}\text { TPC, TFC, } \\
\text { FRAP, } \\
\text { DPPH, } \\
\text { ABTS }\end{array}$ \\
\hline $\begin{array}{l}\text { Futui and } \\
\text { Thongwai } \\
2020\end{array}$ & [45] & Thailand & multifloral & $\begin{array}{l}\text { Stored at } \\
-20^{\circ} \mathrm{C}\end{array}$ & $\begin{array}{l}\text { Powdered } \\
\text { (method } \\
\text { not indi- } \\
\text { cated) }\end{array}$ & Maceration & Water & $1: 10$ & $45^{\circ} \mathrm{C}$ & None & $3 \mathrm{~h}$ & 3 & $\begin{array}{c}\text { Filtered, } \\
\text { dried in } \\
\text { vacuo, } \\
\text { lyophilised }\end{array}$ & $\begin{array}{c}\text { TPC, TFC, } \\
\text { DPPH }\end{array}$ \\
\hline
\end{tabular}


Table 1. Cont.

\begin{tabular}{|c|c|c|c|c|c|c|c|c|c|c|c|c|c|c|}
\hline Author & Reference & Country & $\begin{array}{c}\text { Botanical } \\
\text { Origin }\end{array}$ & $\begin{array}{c}\text { Pre- } \\
\text { Extraction }\end{array}$ & $\begin{array}{c}\text { Pulve- } \\
\text { Risation }\end{array}$ & $\begin{array}{l}\text { Extraction } \\
\text { Method }\end{array}$ & Solvent & $\begin{array}{c}\text { Volume } \\
\text { of } \\
\text { Solvent }\end{array}$ & $\begin{array}{c}\text { Extraction } \\
\text { Tempe- } \\
\text { Rature } \\
\end{array}$ & $\begin{array}{c}\text { Mixing/ } \\
\text { Power }\end{array}$ & $\begin{array}{l}\text { Extraction } \\
\text { Time }\end{array}$ & $\begin{array}{l}\text { No. of } \\
\text { Extrac- } \\
\text { tions }\end{array}$ & $\begin{array}{c}\text { Post- } \\
\text { Extraction }\end{array}$ & $\begin{array}{l}\text { Antioxidant } \\
\text { Assays }\end{array}$ \\
\hline $\begin{array}{c}\text { Futui and } \\
\text { Thongwai } \\
2020\end{array}$ & [45] & Thailand & multifloral & $\begin{array}{l}\text { Stored at } \\
-20^{\circ} \mathrm{C}\end{array}$ & $\begin{array}{l}\text { Powdered } \\
\text { (method } \\
\text { not indi- } \\
\text { cated) }\end{array}$ & Maceration & $\begin{array}{c}95 \% \\
\text { Ethanol } \\
\text { (Aqueous) }\end{array}$ & $1: 10$ & RT & None & $\begin{array}{c}72 \mathrm{~h} \\
\text { (solvent } \\
\text { renewal } \\
\text { every } \\
24 \mathrm{~h} \text { ) }\end{array}$ & 3 & $\begin{array}{c}\text { Filtered, } \\
\text { dried in } \\
\text { vacuo, } \\
\text { lyophilised }\end{array}$ & $\begin{array}{c}\text { TPC, TFC, } \\
\text { DPPH }\end{array}$ \\
\hline $\begin{array}{c}\text { Futui and } \\
\text { Thongwai } \\
2020\end{array}$ & [45] & Thailand & multifloral & $\begin{array}{l}\text { Stored at } \\
-20^{\circ} \mathrm{C}\end{array}$ & $\begin{array}{l}\text { Powdered } \\
\text { (method } \\
\text { not indi- } \\
\text { cated) }\end{array}$ & Sonication & Water & $1: 10$ & RT & N.I. & $30 \mathrm{~min}$ & 2 & $\begin{array}{c}\text { Filtered, } \\
\text { dried in } \\
\text { vacuo, } \\
\text { lyophilised }\end{array}$ & $\begin{array}{c}\text { TPC, TFC, } \\
\text { DPPH }\end{array}$ \\
\hline $\begin{array}{l}\text { Nurdianah, } \\
\text { Ahmad } \\
\text { Firdaus } \\
\text { et al., } 2016\end{array}$ & [46] & Malaysia & multifloral & $\begin{array}{l}\text { Stored at } \\
4{ }^{\circ} \mathrm{C}\end{array}$ & None & Maceration & Ethanol & $10 \mathrm{~g} /$ & RT & N.I. & $24 \mathrm{~h}$ & 1 & $\begin{array}{c}\text { Filtered, } \\
\text { dried in } \\
\text { vacuo, } \\
\text { lyophilised, } \\
4\end{array}$ & $\mathrm{DPPH}$ \\
\hline $\begin{array}{l}\text { Fatrcova- } \\
\text { Sramkova, } \\
\text { Nozkova } \\
\text { et al., } 2013\end{array}$ & [47] & Slovak & $\begin{array}{c}\text { Poppy } \\
\text { (Papaver } \\
\text { somniferum } \\
\text { L.), Rape } \\
\text { (Brassica napus } \\
\text { subsp. napus } \\
\text { L.), Sunflower } \\
\text { (Helianthus } \\
\text { annuus L.). }\end{array}$ & $\begin{array}{c}\text { Stored at } \\
-18^{\circ} \mathrm{C}\end{array}$ & $\begin{array}{l}\text { Homogen- } \\
\text { ised }\end{array}$ & Maceration & $\begin{array}{c}90 \% \\
\text { Ethanol } \\
\text { (Aqueous) }\end{array}$ & $5 \mathrm{~g} / 50 \mathrm{~mL}$ & $70^{\circ} \mathrm{C}$ & N.I. & $30 \mathrm{~min}$ & & N.I. & $\begin{array}{l}\text { DPPH, } \\
\text { Reducing } \\
\text { Power }\end{array}$ \\
\hline $\begin{array}{l}\text { Sun, Guo } \\
\text { et al., } 2017\end{array}$ & [48] & China & Rape & $\begin{array}{c}\text { Defatted } \\
\text { with hexane }\end{array}$ & None & Sonication & $\begin{array}{c}70 \% \\
\text { Methanol } \\
\text { (Aqueous) }\end{array}$ & N.I & RT & N.I & $60 \mathrm{~min}$ & & N.I. & $\begin{array}{c}\text { TPC, TFC, } \\
\text { DPPH, } \\
\text { FRAP, ABTS }\end{array}$ \\
\hline $\begin{array}{c}\text { Borycka, } \\
\text { Grabek- } \\
\text { Lejko } \\
\text { et al., } 2016\end{array}$ & [10] & Poland & multifloral & N.I. & $\begin{array}{c}\text { Ground } \\
\text { using } \\
\text { mortar } \\
\text { and } \\
\text { pestle }\end{array}$ & Agitation & Water & $2 \mathrm{~g} / 15 \mathrm{~mL}$ & $70^{\circ} \mathrm{C}$ & N.I. & $30 \mathrm{~min}$ & & $\begin{array}{c}\text { Filtered } \\
\text { using } \\
\text { Whatman } \\
\# 1 \text { and } \\
\text { dried in } \\
\text { vacuo }\end{array}$ & $\begin{array}{c}\text { TPC, TFC, } \\
\text { DPPH, } \\
\text { FRAP, } \\
\text { ABTS, }\end{array}$ \\
\hline $\begin{array}{c}\text { Borycka, } \\
\text { Grabek- } \\
\text { Lejko } \\
\text { et al., } 2016\end{array}$ & [10] & Poland & multifloral & N.I. & $\begin{array}{l}\text { Ground } \\
\text { using } \\
\text { mortar } \\
\text { and } \\
\text { pestle }\end{array}$ & Agitation & $\begin{array}{c}70 \% \\
\text { Ethanol } \\
\text { (Aqueous) }\end{array}$ & $2 \mathrm{~g} / 15 \mathrm{~mL}$ & $70^{\circ} \mathrm{C}$ & N.I. & $30 \mathrm{~min}$ & & $\begin{array}{c}\text { Filtered } \\
\text { using- } \\
\text { Whatman } \\
\# 1 \text { and } \\
\text { dried in } \\
\text { vacuo }\end{array}$ & $\begin{array}{c}\text { TPC, TFC, } \\
\text { DPPH, } \\
\text { FRAP, ABTS }\end{array}$ \\
\hline
\end{tabular}


Table 1. Cont.

\begin{tabular}{|c|c|c|c|c|c|c|c|c|c|c|c|c|c|c|}
\hline Author & Reference & Country & $\begin{array}{c}\text { Botanical } \\
\text { Origin }\end{array}$ & $\begin{array}{c}\text { Pre- } \\
\text { Extraction }\end{array}$ & $\begin{array}{l}\text { Pulve- } \\
\text { Risation }\end{array}$ & $\begin{array}{l}\text { Extraction } \\
\text { Method }\end{array}$ & Solvent & $\begin{array}{c}\begin{array}{c}\text { Volume } \\
\text { of } \\
\text { Solvent }\end{array} \\
\end{array}$ & $\begin{array}{c}\text { Extraction } \\
\text { Tempe- } \\
\text { Rature } \\
\end{array}$ & $\begin{array}{c}\text { Mixing/ } \\
\text { Power }\end{array}$ & $\begin{array}{l}\text { Extraction } \\
\text { Time }\end{array}$ & $\begin{array}{l}\text { No. of } \\
\text { Extrac- } \\
\text { tions }\end{array}$ & $\begin{array}{c}\text { Post- } \\
\text { Extraction }\end{array}$ & $\begin{array}{l}\text { Antioxidant } \\
\text { Assays }\end{array}$ \\
\hline $\begin{array}{l}\text { Borycka, } \\
\text { Grabek- } \\
\text { Lejko } \\
\text { et al., } 2016\end{array}$ & [10] & Poland & multifloral & N.I. & $\begin{array}{l}\text { Ground } \\
\text { using } \\
\text { mortar } \\
\text { and } \\
\text { pestle }\end{array}$ & Agitation & $\begin{array}{c}70 \% \\
\text { Methanol } \\
\text { (Aqueous) }\end{array}$ & $2 \mathrm{~g} / 15 \mathrm{~mL}$ & $70^{\circ} \mathrm{C}$ & N.I. & $30 \mathrm{~min}$ & 1 & $\begin{array}{l}\text { Filtered, } \\
\text { using } \\
\text { Whatman } \\
\# 1 \text { and } \\
\text { dried in } \\
\text { vacuo }\end{array}$ & $\begin{array}{c}\text { TPC, TFC, } \\
\text { DPPH, } \\
\text { FRAP, ABTS }\end{array}$ \\
\hline $\begin{array}{l}\text { Su, Yang } \\
\text { et al., } 2020\end{array}$ & [49] & China & $\begin{array}{l}\text { Camellia, } \\
\text { Rape, Rose, } \\
\text { and Lotus }\end{array}$ & N.I. & $\begin{array}{l}\text { Mechanical } \\
\text { pulveri- } \\
\text { sation }\end{array}$ & Sonication & Methanol & $1: 10$ & $30^{\circ} \mathrm{C}$ & $100 \mathrm{~W}$ & $1 \mathrm{~h}$ & 1 & $\begin{array}{c}\text { Filtered, } \\
\text { dried in } \\
\text { vacuo }\end{array}$ & $\begin{array}{l}\text { TPC, DPPH, } \\
\text { RP, ABTS }\end{array}$ \\
\hline $\begin{array}{c}\text { Uçar, } \\
\text { Barlak } \\
\text { et al., } 2017\end{array}$ & {$[50]$} & Turkey & multifloral & N.I. & $\begin{array}{l}\text { Ground } \\
\text { (method } \\
\text { not indi- } \\
\text { cated) }\end{array}$ & Agitation & DMSO & $\begin{array}{l}5 \mathrm{gw} / \\
20 \mathrm{~mL}\end{array}$ & $60^{\circ} \mathrm{C}$ & $150 \mathrm{rpm}$ & $24 \mathrm{~h}$ & 1 & Centrifuged & $\begin{array}{l}\text { TPC, TFC, } \\
\text { FRAP, ABTS }\end{array}$ \\
\hline $\begin{array}{c}\text { Uçar, } \\
\text { Barlak } \\
\text { et al., } 2017\end{array}$ & [50] & Turkey & multifloral & N.I. & $\begin{array}{l}\text { Ground } \\
\text { (method } \\
\text { not indi- } \\
\text { cated) }\end{array}$ & Agitation & Water & $\begin{array}{l}5 \mathrm{~g} \mathrm{w} / \\
20 \mathrm{~mL}\end{array}$ & $60^{\circ} \mathrm{C}$ & $150 \mathrm{rpm}$ & $24 \mathrm{~h}$ & 1 & Centrifuged & $\begin{array}{l}\text { TPC, TFC, } \\
\text { FRAP, ABTS }\end{array}$ \\
\hline $\begin{array}{c}\text { Oroian, } \\
\text { Ursachi } \\
\text { et al., } 2020\end{array}$ & [51] & Romania & multifloral & $\begin{array}{l}\text { Stored at } \\
-20^{\circ} \mathrm{C}\end{array}$ & None & Sonication & $\begin{array}{c}80 \% \\
\text { Methanol } \\
\text { (Aqueous) }\end{array}$ & $1: 10-30$ & $\begin{array}{l}35^{\circ} \mathrm{C}, \\
50^{\circ} \mathrm{C}, \\
65^{\circ} \mathrm{C}\end{array}$ & $100 \mathrm{~W}$. & $10-30 \mathrm{~min}$ & 1 & N.I. & TPC, TFC \\
\hline $\begin{array}{l}\text { Barbieri, } \\
\text { Gabriele } \\
\text { et al., } 2020\end{array}$ & [52] & Italy & multifloral & $\begin{array}{l}\text { Stored at } \\
-20^{\circ} \mathrm{C}\end{array}$ & $\begin{array}{l}\text { Powdered } \\
\text { with } \\
\text { mortar } \\
\text { and } \\
\text { pestle }\end{array}$ & Agitation & $\begin{array}{c}95 \% \\
\text { Ethanol } \\
\text { (Aqueous) }\end{array}$ & $50 \mathrm{mg} / \mathrm{mL}$ & RT & N.I. & $1 \mathrm{~h}$ & N.I. & N.I. & $\begin{array}{c}\text { TPC, TFC, } \\
\text { FRAP }\end{array}$ \\
\hline $\begin{array}{l}\text { Shen, } \\
\text { Geng } \\
\text { et al., } 2019\end{array}$ & [53] & China & $\begin{array}{l}\text { Schisandra } \\
\text { chinensis }\end{array}$ & $\begin{array}{c}\text { Dried at } \\
37^{\circ} \mathrm{C}\end{array}$ & $\begin{array}{l}\text { Pulverised } \\
\text { (method } \\
\text { not indi- } \\
\text { cated) }\end{array}$ & Refluxed & $\begin{array}{c}70 \% \\
\text { Ethanol } \\
\text { (Aqueous) }\end{array}$ & $1: 15$ & $\begin{array}{c}\text { Boling } \\
\text { Point }\end{array}$ & None & $2 \mathrm{~h}$ & N.I. & $\begin{array}{l}\text { Centrifuged, } \\
\text { dried in } \\
\text { vacuo, } \\
\text { freeze } \\
\text { dried }\end{array}$ & $\begin{array}{l}\text { ABTS, } \\
\text { FRAP }\end{array}$ \\
\hline $\begin{array}{c}\text { Saral, } \\
\text { Yildiz } \\
\text { et al., } 2016\end{array}$ & [54] & Turkey & $\begin{array}{l}\text { Castanea } \\
\text { sativa L. }\end{array}$ & N.I. & None & $\begin{array}{l}\text { Maceration } \\
\text { and } \\
\text { sonication }\end{array}$ & Methanol & $5 \mathrm{~g} / 100 \mathrm{~mL}$ & RT & N.I. & $24 \mathrm{~h}, 3 \mathrm{~h}$ & N.I. & $\begin{array}{l}\text { Filtered, } \\
\text { fried in } \\
\text { vacuo }\end{array}$ & $\begin{array}{c}\text { TPC, FRAP, } \\
\text { DPPH }\end{array}$ \\
\hline $\begin{array}{c}\text { Pérez- } \\
\text { Pérez, Vit } \\
\text { et al., } 2012\end{array}$ & [55] & Venezuela & multifloral & N.I. & $\begin{array}{l}\text { Ground } \\
\text { in a } \\
\text { mortar, } \\
\text { frozen }\end{array}$ & homogenised & Water & $0.1 \mathrm{~g} / 5 \mathrm{~mL}$ & $4{ }^{\circ} \mathrm{C}$ & N.I. & N.I. & N.I. & Centrifuged & TPC, ABTS \\
\hline
\end{tabular}


Table 1. Cont.

\begin{tabular}{|c|c|c|c|c|c|c|c|c|c|c|c|c|c|c|}
\hline Author & Reference & Country & $\begin{array}{c}\text { Botanical } \\
\text { Origin }\end{array}$ & $\begin{array}{c}\text { Pre- } \\
\text { Extraction }\end{array}$ & $\begin{array}{c}\text { Pulve- } \\
\text { Risation }\end{array}$ & $\begin{array}{l}\text { Extraction } \\
\text { Method }\end{array}$ & Solvent & $\begin{array}{c}\text { Volume } \\
\text { of } \\
\text { Solvent }\end{array}$ & $\begin{array}{c}\text { Extraction } \\
\text { Tempe- } \\
\text { Rature } \\
\end{array}$ & $\underset{\text { Power }}{\text { Mixing/ }}$ & $\begin{array}{l}\text { Extraction } \\
\text { Time }\end{array}$ & $\begin{array}{l}\text { No. of } \\
\text { Extrac- } \\
\text { tions }\end{array}$ & $\begin{array}{c}\text { Post- } \\
\text { Extraction }\end{array}$ & $\begin{array}{l}\text { Antioxidant } \\
\text { Assays }\end{array}$ \\
\hline $\begin{array}{l}\text { Pérez- } \\
\text { Pérez, Vit } \\
\text { et al., } 2012\end{array}$ & [55] & Venezuela & multifloral & N.I. & $\begin{array}{c}\text { Ground } \\
\text { in a } \\
\text { mortar, } \\
\text { frozen }\end{array}$ & homogenised & Methanol & $0.1 \mathrm{~g} / 5 \mathrm{~mL}$ & $4^{\circ} \mathrm{C}$ & N.I. & N.I. & N.I. & Centrifuged & TPC, ABTS \\
\hline $\begin{array}{l}\text { Pérez- } \\
\text { Pérez, Vit } \\
\text { et al., } 2012\end{array}$ & [55] & Venezuela & multifloral & N.I. & $\begin{array}{l}\text { Ground } \\
\text { in a } \\
\text { mortar, } \\
\text { frozen }\end{array}$ & homogenised & $\begin{array}{c}95 \% \\
\text { Ethanol } \\
\text { (Aqueous) }\end{array}$ & $0.1 \mathrm{~g} / 5 \mathrm{~mL}$ & $4^{\circ} \mathrm{C}$ & N.I. & N.I. & N.I. & Centrifuged & TPC, ABTS \\
\hline $\begin{array}{l}\text { Daudu } \\
2019\end{array}$ & [56] & Nigeria & multifloral & $\begin{array}{l}\text { Oven dried } \\
\text { at } 40^{\circ} \mathrm{C}\end{array}$ & $\begin{array}{l}\text { Ground } \\
\text { (method } \\
\text { not indi- } \\
\text { cated) }\end{array}$ & Maceration & Methanol & $0.5 \mathrm{~g} / 5 \mathrm{~mL}$ & N.I. & N.I. & N.I. & N.I. & Filtered & $\begin{array}{c}\text { TPC, TFC, } \\
\text { NO2, } \\
\text { DPPH, TAC, } \\
\text { RP, Metal } \\
\text { Chelating }\end{array}$ \\
\hline $\begin{array}{l}\text { Daudu } \\
2019\end{array}$ & [56] & Nigeria & multifloral & $\begin{array}{l}\text { Oven dried } \\
\text { at } 40^{\circ} \mathrm{C}\end{array}$ & $\begin{array}{l}\text { Ground } \\
\text { (method } \\
\text { not indi- } \\
\text { cated) }\end{array}$ & Maceration & Water & $0.5 \mathrm{~g} / 5 \mathrm{~mL}$ & N.I. & N.I. & N.I. & N.I. & Filtered & $\begin{array}{c}\text { TPC, TFC, } \\
\text { NO2, } \\
\text { DPPH, TAC, } \\
\text { RP, Metal } \\
\text { Chelating }\end{array}$ \\
\hline $\begin{array}{l}\text { Daudu } \\
2019\end{array}$ & [56] & Nigeria & multifloral & $\begin{array}{l}\text { Oven dried } \\
\text { at } 40^{\circ} \mathrm{C}\end{array}$ & $\begin{array}{l}\text { Ground } \\
\text { (method } \\
\text { not indi- } \\
\text { cated) }\end{array}$ & Maceration & Ethanol & $0.5 \mathrm{~g} / 5 \mathrm{~mL}$ & N.I. & N.I. & N.I. & N.I. & Filtered & $\begin{array}{c}\text { TPC, TFC, } \\
\text { NO2, } \\
\text { DPPH, TAC, } \\
\text { RP, Metal } \\
\text { Chelating }\end{array}$ \\
\hline $\begin{array}{l}\text { Stanciu, } \\
\text { Dezmirean } \\
\text { et al., } 2016\end{array}$ & [57] & Romania & multifloral & $\begin{array}{l}\text { Stored at } \\
-18^{\circ} \mathrm{C}\end{array}$ & $\begin{array}{l}\text { Ground } \\
\text { (method } \\
\text { not indi- } \\
\text { cated) }\end{array}$ & N.I. & $\begin{array}{c}\text { Hexane:dich } \\
\text { loromethane } \\
1: 1\end{array}$ & N.I. & N.I. & N.I. & $1 \mathrm{~h}$ & N.I. & N.I. & $\begin{array}{l}\text { TPC, Total } \\
\text { carotenoid, } \\
\text { ORAC }\end{array}$ \\
\hline $\begin{array}{l}\text { Stanciu, } \\
\text { Dezmirean } \\
\text { et al., } 2016\end{array}$ & [57] & Romania & multifloral & $\begin{array}{l}\text { Stored at } \\
-18^{\circ} \mathrm{C}\end{array}$ & $\begin{array}{l}\text { Ground } \\
\text { (method } \\
\text { not indi- } \\
\text { cated) }\end{array}$ & N.I. & $\begin{array}{c}\text { acetone: } \\
\text { water:acetic } \\
\text { acid } \\
70: 29.5: 0.5\end{array}$ & N.I. & N.I. & N.I. & $1 \mathrm{~h}$ & N.I. & N.I. & $\begin{array}{l}\text { TPC, Total } \\
\text { carotenoid, } \\
\text { ORAC }\end{array}$ \\
\hline
\end{tabular}


Table 1. Cont.

\begin{tabular}{|c|c|c|c|c|c|c|c|c|c|c|c|c|c|c|}
\hline Author & Reference & Country & $\begin{array}{c}\text { Botanical } \\
\text { Origin }\end{array}$ & $\begin{array}{c}\text { Pre- } \\
\text { Extraction }\end{array}$ & $\begin{array}{l}\text { Pulve- } \\
\text { Risation }\end{array}$ & $\begin{array}{l}\text { Extraction } \\
\text { Method }\end{array}$ & Solvent & $\begin{array}{c}\begin{array}{c}\text { Volume } \\
\text { of } \\
\text { Solvent }\end{array} \\
\end{array}$ & $\begin{array}{c}\text { Extraction } \\
\text { Tempe- } \\
\text { Rature } \\
\end{array}$ & $\underset{\text { Power }}{\text { Mixing/ }}$ & $\begin{array}{l}\text { Extraction } \\
\text { Time }\end{array}$ & $\begin{array}{l}\text { No. of } \\
\text { Extrac- } \\
\text { tions }\end{array}$ & $\begin{array}{c}\text { Post- } \\
\text { Extraction }\end{array}$ & $\begin{array}{l}\text { Antioxidant } \\
\text { Assays }\end{array}$ \\
\hline $\begin{array}{c}\text { Mayda, } \\
\text { Özkök } \\
\text { et al., } 2020\end{array}$ & [58] & Turkey & multifloral & $\begin{array}{l}\text { Stored at } \\
-18^{\circ} \mathrm{C}\end{array}$ & None & $\begin{array}{l}\text { Agitation } \\
\text { and } \\
\text { sonication }\end{array}$ & $\begin{array}{c}95 \% \\
\text { Ethanol } \\
\text { (Aqueous) }\end{array}$ & $\begin{array}{l}1.5 \mathrm{~g} / \\
10 \mathrm{~mL}\end{array}$ & $40^{\circ} \mathrm{C}$ & $\begin{array}{l}\text { Vortex } \\
\text { Mixer }\end{array}$ & $60 \mathrm{~min}$ & N.I. & $\begin{array}{l}\text { Filtered } \\
\text { through } \\
0.45 \mu \mathrm{m} \\
\text { filter }\end{array}$ & $\begin{array}{c}\text { TPC, TFC, } \\
\text { DPPH, } \\
\text { ABTS }\end{array}$ \\
\hline $\begin{array}{c}\text { Anjos, } \\
\text { Fernandes } \\
\text { et al., } 2019\end{array}$ & [59] & Portugal & multifloral & $\begin{array}{l}\text { Stored at } \\
-18{ }^{\circ} \mathrm{C}\end{array}$ & None & Agitation & $\begin{array}{c}80 \% \\
\text { Ethanol } \\
\text { (Aqueous) }\end{array}$ & $11 \mathrm{~g} /$ & RT & $4 \times g$ & $24 \mathrm{~h}$ & N.I. & $\begin{array}{l}\text { Centrifuged, } \\
\text { dried in } \\
\text { vacuo, } \\
\text { freeze } \\
\text { dried }\end{array}$ & $\begin{array}{l}\text { TPC, TFC, } \\
\text { DPPH, RP }\end{array}$ \\
\hline $\begin{array}{l}\text { Almeida, } \\
\text { Reis et al., } \\
2017\end{array}$ & [60] & Brazil & multifloral & N.I. & None & Agitation & $\begin{array}{c}80 \% \\
\text { Ethanol } \\
\text { (Aqueous) }\end{array}$ & $10 \mathrm{~g} /$ & $40^{\circ} \mathrm{C}$ & $150 \mathrm{rpm}$ & $60 \mathrm{~min}$ & N.I. & $\begin{array}{c}\text { Filtered, } \\
\text { dried in } \\
\text { vacuo, } \\
\text { freeze } \\
\text { dried }\end{array}$ & $\begin{array}{c}\text { TPC, TFC, } \\
\text { ABTS, } \\
\text { DPPH, } \\
\text { FRAP, } \\
\text { Coupled } \\
\text { oxidation of } \\
\text { b-carotene } \\
\text { and linoleic } \\
\text { acid assay }\end{array}$ \\
\hline $\begin{array}{c}\text { Fatrcova- } \\
\text { Sramkova, } \\
\text { Nozkova } \\
\text { et al., } 2016\end{array}$ & [61] & Slovakia & $\begin{array}{l}\text { Helianthus } \\
\text { annuus }\end{array}$ & $\begin{array}{c}\text { Stored at } \\
35^{\circ} \mathrm{C}\end{array}$ & $\begin{array}{l}\text { Homogen- } \\
\text { ised } \\
\text { (method } \\
\text { not indi- } \\
\text { cated) }\end{array}$ & Maceration & $\begin{array}{c}90 \% \\
\text { Ethanol } \\
\text { (Aqueous) }\end{array}$ & $\begin{array}{c}5 \mathrm{~g} / \\
50 \mathrm{~mL}\end{array}$ & $70{ }^{\circ} \mathrm{C}$ & N.I. & $30 \mathrm{~min}$ & N.I. & $\begin{array}{l}\text { Stored at } \\
5^{\circ} \mathrm{C}\end{array}$ & $\begin{array}{c}\text { TPC, } \\
\text { Carote- } \\
\text { niods, RP, } \\
\text { Flavonoids }\end{array}$ \\
\hline $\begin{array}{c}\text { Mosic, } \\
\text { Trifkovic } \\
\text { et al., } 2019\end{array}$ & [62] & Serbia & multifloral & N.I. & None & Sonication & $\begin{array}{c}70 \% \\
\text { Methanol } \\
\text { (Aqueous) }\end{array}$ & $10 \mathrm{~g} /$ & N.I. & N.I. & $1 \mathrm{~h}$ & N.I. & N.I. & TPC \\
\hline $\begin{array}{c}\text { El } \\
\text { Ghouizi, } \\
\text { Menyiy } \\
\text { et al., } 2020\end{array}$ & [63] & Morocco & multifloral & N.I. & None & Agitation & $\begin{array}{c}70 \% \\
\text { Ethanol } \\
\text { (Aqueous) }\end{array}$ & $15 \mathrm{~g} /$ & $70^{\circ} \mathrm{C}$ & N.I. & $30 \mathrm{~min}$ & N.I & $\begin{array}{c}\text { Filtered } \\
\text { using } \\
\text { Whatman } \\
\# 5\end{array}$ & $\begin{array}{l}\text { TPC, TFC, } \\
\text { TAC, RP }\end{array}$ \\
\hline $\begin{array}{c}\text { Rebiai } \\
\text { and Lane } \\
2012\end{array}$ & [64] & Algeria & $\begin{array}{c}\text { Carrot, } \\
\text { Rosemary, } \\
\text { Eucalyptus, } \\
\text { and } \\
\text { multifloral }\end{array}$ & $\begin{array}{l}\text { Stored at } \\
4^{\circ} \mathrm{C}\end{array}$ & $\begin{array}{l}\text { Homogen- } \\
\text { ised in } \\
\text { blender }\end{array}$ & Soxhlet & Methanol & $\begin{array}{c}5 \mathrm{~g} \mathrm{w} / \\
175 \mathrm{~mL}\end{array}$ & $70 \mathrm{C}$ & None & $2 \mathrm{~h}$ & 1 & $\begin{array}{l}\text { Dried in } \\
\text { vacuo }\end{array}$ & $\begin{array}{c}\text { TPC, TFC, } \\
\text { TAC }\end{array}$ \\
\hline
\end{tabular}


Table 1. Cont.

\begin{tabular}{|c|c|c|c|c|c|c|c|c|c|c|c|c|c|c|}
\hline Author & Reference & Country & $\begin{array}{c}\text { Botanical } \\
\text { Origin }\end{array}$ & $\begin{array}{c}\text { Pre- } \\
\text { Extraction }\end{array}$ & $\begin{array}{c}\text { Pulve- } \\
\text { Risation }\end{array}$ & $\begin{array}{l}\text { Extraction } \\
\text { Method }\end{array}$ & Solvent & $\begin{array}{l}\text { Volume } \\
\text { of } \\
\text { Solvent }\end{array}$ & $\begin{array}{c}\text { Extraction } \\
\text { Tempe- } \\
\text { Rature }\end{array}$ & $\begin{array}{c}\text { Mixing/ } \\
\text { Power }\end{array}$ & $\begin{array}{c}\text { Extraction } \\
\text { Time }\end{array}$ & $\begin{array}{l}\text { No. of } \\
\text { Extrac- } \\
\text { tions }\end{array}$ & $\begin{array}{c}\text { Post- } \\
\text { Extraction }\end{array}$ & $\begin{array}{l}\text { Antioxidant } \\
\text { Assays }\end{array}$ \\
\hline $\begin{array}{c}\text { Araujo, } \\
\text { Chambo } \\
\text { et al., } 2017\end{array}$ & [65] & Brazil & $\begin{array}{l}\text { Cocos nucifera, } \\
\text { Miconia spp., } \\
\text { Spondias spp., } \\
\text { Myrcia spp., } \\
\text { Eucalyptus } \\
\text { spp. }\end{array}$ & N.I. & None & Agitation & Methanol & $1: 1$ & N.I. & N.I. & $24 \mathrm{~h}$ & 3 & $\begin{array}{l}\text { Dried in } \\
\text { vacuo }\end{array}$ & $\begin{array}{l}\text { TPC, TFC, } \\
\text { DPPH, A } \\
\text { BTS }\end{array}$ \\
\hline $\begin{array}{c}\text { Barbara, } \\
\text { Machado } \\
\text { et al., } 2015\end{array}$ & [66] & Brazil & multifloral & N.I. & None & Agitation & Methanol & $1: 1$ & N.I. & N.I. & $24 \mathrm{~h}$ & 3 & $\begin{array}{l}\text { Dried in } \\
\text { vacuo }\end{array}$ & TPC, TFC \\
\hline $\begin{array}{c}\text { Carpes, } \\
\text { Mourao } \\
\text { et al., } 2009\end{array}$ & [67] & Brazil & multifloral & $\begin{array}{c}\text { Stored at } \\
-12 \text { to } \\
-15{ }^{\circ} \mathrm{C}\end{array}$ & $\begin{array}{l}\text { Crushed } \\
\text { using } \\
\text { commer- } \\
\text { cial } \\
\text { blender }\end{array}$ & Maceration & $\begin{array}{c}70 \% \\
\text { Ethanol } \\
\text { (Aqueous) }\end{array}$ & $2 \mathrm{~g} / 15 \mathrm{~mL}$ & $70^{\circ} \mathrm{C}$ & None & $30 \mathrm{~min}$ & N.I. & $\begin{array}{l}\text { Filtered } \\
\text { and } \\
\text { stored }\end{array}$ & $\begin{array}{c}\text { TPC, TFC, } \\
\text { DPPH }\end{array}$ \\
\hline $\begin{array}{l}\text { Sartini, } \\
\text { Djide } \\
\text { et al., } 2019\end{array}$ & [68] & Indonesia & multifloral & N.I. & $\begin{array}{l}\text { Coarse } \\
\text { powder } \\
\text { (method } \\
\text { not indi- } \\
\text { cated) }\end{array}$ & Maceration & $\begin{array}{c}80 \% \\
\text { Ethanol } \\
\text { (Aqueous) }\end{array}$ & $\begin{array}{c}100 \mathrm{~g} / \\
1 \mathrm{~L}\end{array}$ & RT & None & $120 \mathrm{~h}$ & N.I. & $\begin{array}{c}\text { Dried in } \\
\text { vacuo, } \\
\text { freeze } \\
\text { dried }\end{array}$ & $\begin{array}{c}\text { TPC, TFC, } \\
\text { DPPH }\end{array}$ \\
\hline $\begin{array}{c}\text { Le Blanc, } \\
\text { Davis } \\
\text { et al., } 2009\end{array}$ & {$[1]$} & USA & $\begin{array}{c}\text { Mesquite, } \\
\text { Yucca, Palm, } \\
\text { Terpentine } \\
\text { Bush, Mimosa } \\
\text { and } \\
\text { Chenopod }\end{array}$ & N.I. & None & Sonication & Methanol & $50 \mathrm{mg} / \mathrm{mL}$ & $41^{\circ} \mathrm{C}$ & None & $90 \mathrm{~min}$ & N.I. & N.I. & $\begin{array}{c}\text { TPC, Total } \\
\text { flavones } \\
\text { and } \\
\text { flavonol, } \\
\text { total } \\
\text { flavonones, } \\
\text { DPPH, } \\
\text { FRAP }\end{array}$ \\
\hline
\end{tabular}


Table 1. Cont.

\begin{tabular}{|c|c|c|c|c|c|c|c|c|c|c|c|c|c|c|}
\hline Author & Reference & Country & $\begin{array}{c}\text { Botanical } \\
\text { Origin }\end{array}$ & $\begin{array}{c}\text { Pre- } \\
\text { Extraction }\end{array}$ & $\begin{array}{c}\text { Pulve- } \\
\text { Risation }\end{array}$ & $\begin{array}{l}\text { Extraction } \\
\text { Method }\end{array}$ & Solvent & $\begin{array}{c}\begin{array}{c}\text { Volume } \\
\text { of } \\
\text { Solvent }\end{array} \\
\end{array}$ & $\begin{array}{c}\text { Extraction } \\
\text { Tempe- } \\
\text { Rature }\end{array}$ & $\begin{array}{c}\text { Mixing/ } \\
\text { Power }\end{array}$ & $\begin{array}{c}\text { Extraction } \\
\text { Time }\end{array}$ & $\begin{array}{l}\text { No. of } \\
\text { Extrac- } \\
\text { tions }\end{array}$ & $\begin{array}{c}\text { Post- } \\
\text { Extraction }\end{array}$ & $\begin{array}{l}\text { Antioxidant } \\
\text { Assays }\end{array}$ \\
\hline $\begin{array}{c}\text { Le Blanc, } \\
\text { Davis } \\
\text { et al., } 2009\end{array}$ & [1] & USA & $\begin{array}{c}\text { Mesquite, } \\
\text { Yucca, Palm, } \\
\text { Terpentine } \\
\text { Bush, Mimosa } \\
\text { and } \\
\text { Chenopod }\end{array}$ & N.I. & None & Sonication & Ethanol & $50 \mathrm{mg} / \mathrm{mL}$ & $41^{\circ} \mathrm{C}$ & None & $90 \mathrm{~min}$ & N.I. & N.I. & $\begin{array}{l}\text { TPC, Total } \\
\text { flavones } \\
\text { and } \\
\text { flavonol, } \\
\text { total } \\
\text { flavonones, } \\
\text { DPPH, } \\
\text { FRAP }\end{array}$ \\
\hline $\begin{array}{l}\text { Le Blanc, } \\
\text { Davis } \\
\text { et al., } 2009\end{array}$ & [1] & USA & $\begin{array}{l}\text { Mesquite, } \\
\text { Yucca, Palm, } \\
\text { Terpentine } \\
\text { Bush, Mimosa } \\
\text { and } \\
\text { Chenopod }\end{array}$ & N.I. & None & Sonication & $\begin{array}{c}2- \\
\text { propanol }\end{array}$ & $50 \mathrm{mg} / \mathrm{mL}$ & $41^{\circ} \mathrm{C}$ & None & $90 \mathrm{~min}$ & N.I. & N.I. & $\begin{array}{c}\text { TPC, Total } \\
\text { flavones } \\
\text { and } \\
\text { flavonol, } \\
\text { total } \\
\text { flavonones, } \\
\text { DPPH, } \\
\text { FRAP }\end{array}$ \\
\hline $\begin{array}{l}\text { Le Blanc, } \\
\text { Davis } \\
\text { et al., } 2009\end{array}$ & [1] & USA & $\begin{array}{c}\text { Mesquite, } \\
\text { Yucca, Palm, } \\
\text { Terpentine } \\
\text { Bush, Mimosa } \\
\text { and } \\
\text { Chenopod }\end{array}$ & N.I. & None & Sonication & Acetone & $50 \mathrm{mg} / \mathrm{mL}$ & $41^{\circ} \mathrm{C}$ & None & $90 \mathrm{~min}$ & N.I. & N.I. & $\begin{array}{c}\text { TPC, Total } \\
\text { flavones } \\
\text { and } \\
\text { flavonol, } \\
\text { total } \\
\text { flavonones, } \\
\text { DPPH, } \\
\text { FRAP }\end{array}$ \\
\hline $\begin{array}{c}\text { Le Blanc, } \\
\text { Davis } \\
\text { et al., } 2009\end{array}$ & [1] & USA & $\begin{array}{c}\text { Mesquite, } \\
\text { Yucca, Palm, } \\
\text { Terpentine } \\
\text { Bush, Mimosa } \\
\text { and } \\
\text { Chenopod }\end{array}$ & N.I. & None & Sonication & DMF & $50 \mathrm{mg} / \mathrm{mL}$ & $41^{\circ} \mathrm{C}$ & None & $90 \mathrm{~min}$ & N.I. & N.I. & $\begin{array}{l}\text { TPC, Total } \\
\text { flavones } \\
\text { and } \\
\text { flavonol, } \\
\text { total } \\
\text { flavonones, } \\
\text { DPPH, } \\
\text { FRAP }\end{array}$ \\
\hline
\end{tabular}


Table 1. Cont.

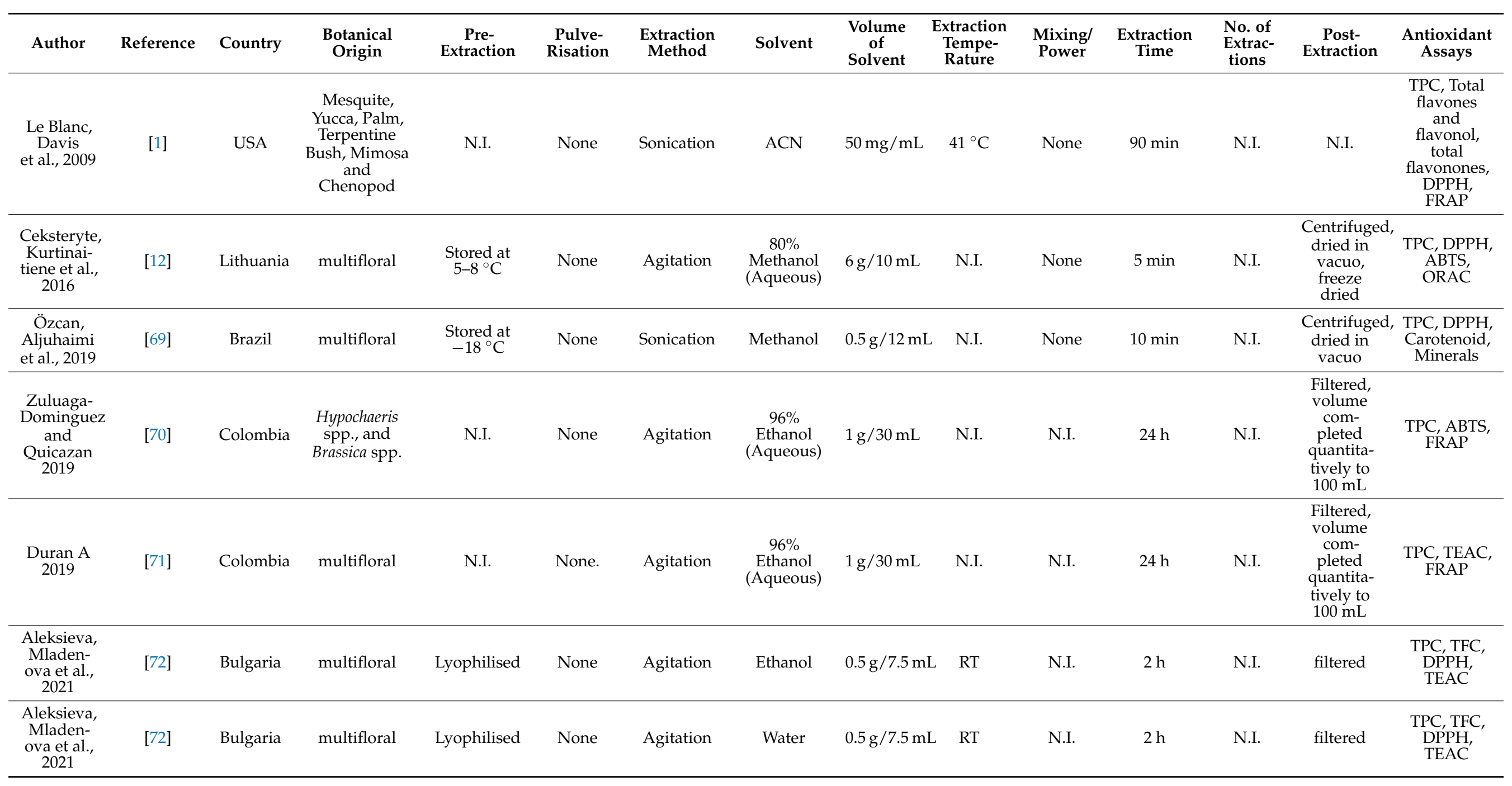


Table 1. Cont.

\begin{tabular}{|c|c|c|c|c|c|c|c|c|c|c|c|c|c|c|}
\hline Author & Reference & Country & $\begin{array}{c}\text { Botanical } \\
\text { Origin }\end{array}$ & $\begin{array}{c}\text { Pre- } \\
\text { Extraction }\end{array}$ & $\begin{array}{l}\text { Pulve- } \\
\text { Risation }\end{array}$ & $\begin{array}{l}\text { Extraction } \\
\text { Method }\end{array}$ & Solvent & $\begin{array}{c}\begin{array}{c}\text { Volume } \\
\text { of } \\
\text { Solvent }\end{array} \\
\end{array}$ & $\begin{array}{l}\text { Extraction } \\
\text { Tempe- } \\
\text { Rature } \\
\end{array}$ & $\underset{\text { Power }}{\text { Mixing/ }}$ & $\begin{array}{l}\text { Extraction } \\
\text { Time }\end{array}$ & $\begin{array}{l}\text { No. of } \\
\text { Extrac- } \\
\text { tions }\end{array}$ & $\begin{array}{c}\text { Post- } \\
\text { Extraction }\end{array}$ & $\begin{array}{l}\text { Antioxidant } \\
\text { Assays }\end{array}$ \\
\hline $\begin{array}{l}\text { Atsalakis, } \\
\text { Chinou } \\
\text { et al., } 2017\end{array}$ & [73], & Greece & Cistus creticus & $\begin{array}{l}\text { Stored at } \\
-20^{\circ} \mathrm{C}\end{array}$ & None & Maceration & $\begin{array}{l}\text { Cyclohex- } \\
\text { ane, } \\
\text { Dichloro- } \\
\text { methane, } \\
\text { Butanol } \\
\text { and Water }\end{array}$ & $\begin{array}{l}27.5 \mathrm{~g} / \\
150 \mathrm{~mL}\end{array}$ & N.I. & None & N.I. & N.I. & N.I. & $\begin{array}{c}\text { TPC, TFC, } \\
\text { DPPH, } \\
\text { ABTS }\end{array}$ \\
\hline $\begin{array}{c}\text { Saral, } \\
\text { Kil- } \\
\text { iÇArslan } \\
\text { et al., } 2019\end{array}$ & [74] & Turkey & multifloral & $\begin{array}{l}\text { Stored at } \\
4^{\circ} \mathrm{C}\end{array}$ & Blended & Maceration & Methanol & N.I. & RT & None & $24 \mathrm{~h}$ & N.I. & $\begin{array}{c}\text { Filtered } \\
\text { using } \\
\text { Whatman } \\
\text { filter } \\
\text { paper \#4 } \\
\text { and then } \\
\text { stored at } \\
4^{\circ} \mathrm{C}\end{array}$ & $\begin{array}{c}\text { TPC, TFC, } \\
\text { CUPRAC, } \\
\text { FRAP, } \\
\text { DPPH }\end{array}$ \\
\hline $\begin{array}{l}\text { Al-Salem, } \\
\text { Al-Yousef } \\
\text { et al., } 2020\end{array}$ & [75] & $\begin{array}{l}\text { Saudi } \\
\text { Arabia }\end{array}$ & multifloral & N.I. & None & Maceration & $\begin{array}{c}95 \% \\
\text { Ethanol } \\
\text { (Aqueous) }\end{array}$ & N.I. & RT & None & $48 \mathrm{~h}$ & N.I. & $\begin{array}{l}\text { Filtered, } \\
\text { dried in } \\
\text { vacuo }\end{array}$ & $\begin{array}{c}\text { Catalase } \\
\text { (CAT) assay, } \\
\text { Vitamin C } \\
\text { (ascorbic } \\
\text { acid) assay, } \\
\text { Glutathione } \\
\text { (GSH) assay, } \\
\text { Glutathione } \\
\text { S- } \\
\text { Transferase } \\
\text { (GST) } \\
\text { activity } \\
\end{array}$ \\
\hline $\begin{array}{l}\text { Gabriele, } \\
\text { Parri et al., } \\
2015\end{array}$ & [76] & Italy & multifloral & $\begin{array}{l}\text { Stored at } \\
-20^{\circ} \mathrm{C}\end{array}$ & None & Agitation & $\begin{array}{c}95 \% \\
\text { Ethanol } \\
\text { (Aqueous) }\end{array}$ & N.I & RT & N.I. & $1 \mathrm{~h}$ & N.I & $\begin{array}{l}\text { Filtered, } \\
\text { stored at } \\
4^{\circ} \mathrm{C}\end{array}$ & $\begin{array}{c}\text { TPC, TFC, } \\
\text { DPPH, } \\
\text { ORAC }\end{array}$ \\
\hline $\begin{array}{l}\text { Yildiz, } \\
\text { Can et al., } \\
2013\end{array}$ & [77] & Turkey & multifloral & $\begin{array}{l}\text { Dried in } \\
40^{\circ} \mathrm{C}\end{array}$ & $\begin{array}{l}\text { Powder } \\
\text { (method } \\
\text { not indi- } \\
\text { cated) }\end{array}$ & Sonication & Methanol & $1 \mathrm{~g} / 10 \mathrm{~mL}$ & N.I. & None & $3 \mathrm{~h}$ & N.I. & Filtered & $\begin{array}{c}\text { TPC, TFC, } \\
\text { Total Antho- } \\
\text { cyanins, } \\
\text { Total } \\
\text { Carotenoids, } \\
\text { FRAP, } \\
\text { DPPH }\end{array}$ \\
\hline $\begin{array}{l}\text { Rocchetti, } \\
\text { Cas- } \\
\text { tiglioni } \\
\text { et al., } 2019\end{array}$ & [78] & Italy & multifloral & $\begin{array}{l}\text { Stored in } \\
\text { the dark at } \\
\text { room } \\
\text { temperature }\end{array}$ & $\begin{array}{l}\text { Ground } \\
\text { (method } \\
\text { not indi- } \\
\text { cated) }\end{array}$ & Agitation & $\begin{array}{c}70 \% \\
\text { Methanol } \\
\text { (Aqueous) }\end{array}$ & $0.5 \mathrm{~g} / 5 \mathrm{~mL}$ & N.I. & Shaking & $5 \mathrm{~min}$ & N.I & $\begin{array}{l}\text { Stored at } \\
-20^{\circ} \mathrm{C}\end{array}$ & $\begin{array}{c}\text { TPC, DPPH, } \\
\text { ABTS, } \\
\text { ORAC }\end{array}$ \\
\hline
\end{tabular}


Table 1. Cont.

\begin{tabular}{|c|c|c|c|c|c|c|c|c|c|c|c|c|c|c|}
\hline Author & Reference & Country & $\begin{array}{c}\text { Botanical } \\
\text { Origin }\end{array}$ & $\begin{array}{c}\text { Pre- } \\
\text { Extraction }\end{array}$ & $\begin{array}{c}\text { Pulve- } \\
\text { Risation }\end{array}$ & $\begin{array}{l}\text { Extraction } \\
\text { Method }\end{array}$ & Solvent & $\begin{array}{l}\text { Volume } \\
\text { of } \\
\text { Solvent }\end{array}$ & $\begin{array}{l}\text { Extraction } \\
\text { Tempe- } \\
\text { Rature } \\
\end{array}$ & $\underset{\text { Power }}{\text { Mixing/ }}$ & $\begin{array}{c}\text { Extraction } \\
\text { Time }\end{array}$ & $\begin{array}{l}\text { No. of } \\
\text { Extrac- } \\
\text { tions }\end{array}$ & $\begin{array}{c}\text { Post- } \\
\text { Extraction }\end{array}$ & $\begin{array}{l}\text { Antioxidant } \\
\text { Assays }\end{array}$ \\
\hline $\begin{array}{l}\text { Yan, } \mathrm{Li} \\
\text { et al., } 2019\end{array}$ & [79] & China & $\begin{array}{c}\text { Brassica } \\
\text { campestris L. }\end{array}$ & N.I. & $\begin{array}{l}\text { Superfine } \\
\text { jet } \\
\text { pulveri- } \\
\text { sation } \\
\text { Combined } \\
\text { low- } \\
\text { pressure } \\
\text { jet- } \\
\text { boiling } \\
\text { device }\end{array}$ & Sonication & $\begin{array}{c}80 \% \\
\text { Acetone } \\
\text { (Aqueous) }\end{array}$ & $2 \mathrm{~g} / 15 \mathrm{~mL}$ & N.I. & None & $30 \mathrm{~min}$ & N.I. & $\begin{array}{l}\text { Freeze } \\
\text { dried and } \\
\text { stored at } \\
-40^{\circ} \mathrm{C}\end{array}$ & TPC \\
\hline $\begin{array}{c}\text { Rebiai } \\
\text { and Lanez } \\
2013\end{array}$ & [80] & Algeria & multifloral & N.I. & None & Maceration & Methanol & $5 \mathrm{~g} / 50 \mathrm{~mL}$ & RT & None & $24 \mathrm{~h}$ & 3 & $\begin{array}{l}\text { Filtered, } \\
\text { refriger- } \\
\text { ated }\end{array}$ & $\begin{array}{c}\text { TPC, TFC, } \\
\text { cyclic } \\
\text { voltamme- } \\
\text { try } \\
\text { techniques }\end{array}$ \\
\hline $\begin{array}{c}\text { Cheng, } \\
\text { Chen } \\
\text { et al., } 2019\end{array}$ & [81] & China & multifloral & N.I. & None & Reflux & $\begin{array}{c}75 \% \\
\text { Ethanol } \\
\text { (Aqueous) }\end{array}$ & $1: 10$ & $75^{\circ} \mathrm{C}$ & None & $2 \mathrm{~h}$ & 2 & $\begin{array}{l}\text { Centrifuged, } \\
\text { dried in } \\
\text { vacuo, }\end{array}$ & $\begin{array}{l}\text { DPPH, } \\
\text { FRAP }\end{array}$ \\
\hline $\begin{array}{c}\text { Muñoz, } \\
\text { Velásquez } \\
\text { et al., } 2020\end{array}$ & [82] & Chile & $\begin{array}{c}\text { Brassica } \\
\text { campestris and } \\
\text { Galega } \\
\text { officinalis }\end{array}$ & $\begin{array}{l}\text { Stored at } \\
-18^{\circ} \mathrm{C}\end{array}$ & None & Sonication & Methanol & $1 \mathrm{~g} / 7.5 \mathrm{~mL}$ & N.I. & $50 \mathrm{~Hz}$. & $30 \mathrm{~min}$ & 1 & $\begin{array}{l}\text { Centrifuged, } \\
\text { filtered at } \\
0.45 \text { um, } \\
\text { refriger- } \\
\text { ated }\end{array}$ & $\begin{array}{c}\text { TPC, TFC, } \\
\text { FRAP }\end{array}$ \\
\hline $\begin{array}{c}\text { Yesiltas, } \\
\text { Ca- } \\
\text { panoglu } \\
\text { et al., } 2015\end{array}$ & [83] & $\begin{array}{l}\text { Turkey } \\
\text { and } \\
\text { Spain }\end{array}$ & multifloral & $\begin{array}{l}\text { Stored at } \\
-18{ }^{\circ} \mathrm{C}\end{array}$ & $\begin{array}{l}\text { Ground } \\
\text { (method } \\
\text { not indi- } \\
\text { cated) }\end{array}$ & $\begin{array}{l}\text { Maceration } \\
\text { and } \\
\text { sonication }\end{array}$ & Methanol & $2 \mathrm{~g} / 15 \mathrm{~mL}$ & RT & N.I. & $\begin{array}{c}3 \mathrm{~d} \\
15 \mathrm{~min}\end{array}$ & 1 & Centrifuged & $\begin{array}{c}\text { TPC, TFC, } \\
\text { ABTS, } \\
\text { FRAP, } \\
\text { DPPH, } \\
\text { CUPRAC }\end{array}$ \\
\hline $\begin{array}{l}\text { Mejias } \\
\text { and Mon- } \\
\text { tenegro } \\
2012\end{array}$ & [84] & Chile & multifloral & N.I. & None & Suspension & Water & N.I. & N.I. & None & N.I. & N.I. & N.I. & $\begin{array}{l}\text { TPC, DPPH, } \\
\text { FRAP }\end{array}$ \\
\hline $\begin{array}{l}\text { Negri, } \\
\text { Teixeira } \\
\text { et al., } 2011\end{array}$ & [85] & Brazil & multifloral & $\begin{array}{l}\text { Stored at } \\
-18^{\circ} \mathrm{C}\end{array}$ & None & Maceration & $\begin{array}{c}70 \% \\
\text { Methanol } \\
\text { (Aqueous) }\end{array}$ & $1.0 \mathrm{~g} / 75 \mathrm{~mL}$ & RT & N.I. & $45 \mathrm{~min}$ & N.I. & $\begin{array}{l}\text { Filtered, } \\
\text { volume } \\
\text { com- } \\
\text { pleted } \\
\text { quantita- } \\
\text { tively to } \\
100 \mathrm{~mL}\end{array}$ & TPC, DPPH \\
\hline
\end{tabular}


Table 1. Cont.

\begin{tabular}{|c|c|c|c|c|c|c|c|c|c|c|c|c|c|c|}
\hline Author & Reference & Country & $\begin{array}{c}\text { Botanical } \\
\text { Origin }\end{array}$ & $\begin{array}{c}\text { Pre- } \\
\text { Extraction }\end{array}$ & $\begin{array}{c}\text { Pulve- } \\
\text { Risation }\end{array}$ & $\begin{array}{l}\text { Extraction } \\
\text { Method }\end{array}$ & Solvent & $\begin{array}{c}\begin{array}{c}\text { Volume } \\
\text { of } \\
\text { Solvent }\end{array} \\
\end{array}$ & $\begin{array}{c}\text { Extraction } \\
\text { Tempe- } \\
\text { Rature }\end{array}$ & $\underset{\text { Power }}{\text { Mixing/ }}$ & $\begin{array}{l}\text { Extraction } \\
\text { Time }\end{array}$ & $\begin{array}{l}\text { No. of } \\
\text { Extrac- } \\
\text { tions }\end{array}$ & $\begin{array}{c}\text { Post- } \\
\text { Extraction }\end{array}$ & $\begin{array}{l}\text { Antioxidant } \\
\text { Assays }\end{array}$ \\
\hline $\begin{array}{l}\text { Campos, } \\
\text { Webby } \\
\text { et al., } 2003\end{array}$ & [86] & $\begin{array}{l}\text { New } \\
\text { Zealand, } \\
\text { Portu- } \\
\text { gal }\end{array}$ & $\begin{array}{l}\text { Salix atrocinera } \\
\text { Brot., } \\
\text { Ranunculus } \\
\text { sardous } \\
\text { Crantz, and } \\
\text { Ulex europeus } \\
\text { L. (Portugal } \\
\text { and New } \\
\text { Zealand); } \\
\text { Eucalyptus } \\
\text { globulus } \\
\text { Labill., Cistus } \\
\text { ladanifer L., } \\
\text { Echium } \\
\text { plantagineum } \\
\text { L., and Erica } \\
\text { australis L. } \\
\text { (Portugal); } \\
\text { and } \\
\text { Metrosideros } \\
\text { umbellata, } \\
\text { Ixerba } \\
\text { brexioides, and } \\
\text { Knightia } \\
\text { excelsa (New } \\
\text { Zealand) }\end{array}$ & N.I. & None & Sonication & $\begin{array}{c}50 \% \\
\text { Ethanol } \\
\text { (Aqueous) }\end{array}$ & N.I. & N.I. & None & N.I. & N.I. & Centrifuged & DPPH \\
\hline $\begin{array}{c}\text { Ulusoy } \\
\text { and } \\
\text { Kolayli } \\
2014\end{array}$ & [87] & Turkey & multifloral & $\begin{array}{l}\text { Stored at } \\
44^{\circ} \mathrm{C}\end{array}$ & None & Sonication & Methanol & N.I. & $\mathrm{RT}$ & None & $1 \mathrm{~h}$ & 3 & $\begin{array}{l}\text { Filtered, } \\
\text { dried in } \\
\text { vacuo }\end{array}$ & $\begin{array}{c}\text { TPC, FRAP, } \\
\text { CUPRAC, } \\
\text { DPPH }\end{array}$ \\
\hline $\begin{array}{l}\text { Mohdaly, } \\
\text { Mah- } \\
\text { moud } \\
\text { et al., } 2015\end{array}$ & [88] & Egypt & $\begin{array}{l}\text { Maize (Zea } \\
\text { mays) }\end{array}$ & $\begin{array}{l}\text { Stored at } \\
4{ }^{\circ} \mathrm{C}\end{array}$ & $\begin{array}{l}\text { Powdered } \\
\text { (method } \\
\text { not indi- } \\
\text { cated) }\end{array}$ & Maceration & Methanol & $\begin{array}{l}10.0 \mathrm{~g} / \\
100 \mathrm{~mL}\end{array}$ & RT & N.I. & $12 \mathrm{~h}$ & 1 & $\begin{array}{c}\text { Filtered } \\
\text { (What- } \\
\text { man \#1), } \\
\text { dried in } \\
\text { vacuo }\end{array}$ & $\begin{array}{l}\text { DPPH, } \\
\text { ABTS }\end{array}$ \\
\hline
\end{tabular}


Table 1. Cont.

\begin{tabular}{|c|c|c|c|c|c|c|c|c|c|c|c|c|c|c|}
\hline Author & Reference & Country & $\begin{array}{c}\text { Botanical } \\
\text { Origin }\end{array}$ & $\begin{array}{c}\text { Pre- } \\
\text { Extraction }\end{array}$ & $\begin{array}{c}\text { Pulve- } \\
\text { Risation }\end{array}$ & $\begin{array}{l}\text { Extraction } \\
\text { Method }\end{array}$ & Solvent & $\begin{array}{l}\text { Volume } \\
\text { of } \\
\text { Solvent }\end{array}$ & $\begin{array}{c}\text { Extraction } \\
\text { Tempe- } \\
\text { Rature }\end{array}$ & $\underset{\text { Power }}{\text { Mixing/ }}$ & $\begin{array}{l}\text { Extraction } \\
\text { Time }\end{array}$ & $\begin{array}{l}\text { No. of } \\
\text { Extrac- } \\
\text { tions }\end{array}$ & $\begin{array}{c}\text { Post- } \\
\text { Extraction }\end{array}$ & $\begin{array}{l}\text { Antioxidant } \\
\text { Assays }\end{array}$ \\
\hline $\begin{array}{l}\text { De-Melo, } \\
\text { Estevinho } \\
\text { et al., } 2018\end{array}$ & [89] & Brazil & $\begin{array}{l}\text { Alternanthera, } \\
\text { Anadenanthera, } \\
\text { Cocos nucifera, } \\
\text { Mimosa cae- } \\
\text { salpiniaefolia, } \\
\text { Myrcia, and } \\
\text { Mimosa } \\
\text { scabrella }\end{array}$ & $\begin{array}{l}\text { Stored at } \\
4{ }^{\circ} \mathrm{C}\end{array}$ & $\begin{array}{l}\text { Crushed } \\
\text { using } \\
\text { commer- } \\
\text { cial } \\
\text { blender }\end{array}$ & Maceration & $\begin{array}{c}70 \% \\
\text { Ethanol } \\
\text { (Aqueous) }\end{array}$ & $2 \mathrm{~g} / 15 \mathrm{~mL}$ & $70{ }^{\circ} \mathrm{C}$ & None & $30 \mathrm{~min}$ & 1 & Filtered & $\begin{array}{l}\text { TPC, TFC, } \\
\text { DPPH }\end{array}$ \\
\hline $\begin{array}{l}\text { Sahin and } \\
\text { Karkar } \\
2019\end{array}$ & [90] & Turkey & Chestnut & N.I. & None & Sonication & Ethanol & $\begin{array}{c}3 \mathrm{~g} / \\
30 \mathrm{~mL}\end{array}$ & $65^{\circ} \mathrm{C}$ & None & $30 \mathrm{~h}$ & 1 & Filtered & $\begin{array}{c}\text { TPC, FRAP, } \\
\text { ABTS, } \\
\text { CHROMAC }\end{array}$ \\
\hline $\begin{array}{l}\text { Belina- } \\
\text { Aldemita, } \\
\text { Schreiner } \\
\text { et al., } 2020\end{array}$ & [91] & Philippines & multifloral & $\begin{array}{c}\text { Under } \\
\text { argon at } \\
-24^{\circ} \mathrm{C}, \\
\text { defatted } \\
\text { with hexane } \\
3 \text { times }\end{array}$ & $\begin{array}{l}\text { Ground } \\
\text { (method } \\
\text { not indi- } \\
\text { cated) }\end{array}$ & Macerated & Methanol & $1 \mathrm{~g} / 5 \mathrm{~mL}$ & $\mathrm{RT}$ & N.I. & $1 \mathrm{~h}$ & 3 & $\begin{array}{l}\text { Centrifuged, } \\
\text { stored at } \\
-20^{\circ} \mathrm{C}\end{array}$ & $\begin{array}{l}\text { TPC, TFC, } \\
\text { and TMAC }\end{array}$ \\
\hline $\begin{array}{l}\text { Belina- } \\
\text { Aldemita, } \\
\text { Schreiner } \\
\text { et al., } 2020\end{array}$ & [91] & Philippines & multifloral & $\begin{array}{c}\text { Under } \\
\text { argon at } \\
-24^{\circ} \mathrm{C}, \\
\text { defatted } \\
\text { with hexane } \\
3 \text { times }\end{array}$ & $\begin{array}{l}\text { Ground } \\
\text { (method } \\
\text { not indi- } \\
\text { cated) }\end{array}$ & Sonication & Methanol & $1 \mathrm{~g} / 5 \mathrm{~mL}$ & $\mathrm{RT}$ & N.I. & $1 \mathrm{~h}$ & 3 & $\begin{array}{l}\text { Centrifuged, } \\
\text { stored at } \\
-20{ }^{\circ} \mathrm{C}\end{array}$ & $\begin{array}{l}\text { TPC, TFC, } \\
\text { and TMAC }\end{array}$ \\
\hline $\begin{array}{l}\text { Belina- } \\
\text { Aldemita, } \\
\text { Schreiner } \\
\text { et al., } 2020\end{array}$ & [91] & Philippines & multifloral & $\begin{array}{c}\text { Under } \\
\text { argon at } \\
-24^{\circ} \mathrm{C}, \\
\text { defatted } \\
\text { with hexane } \\
3 \text { times }\end{array}$ & $\begin{array}{l}\text { Ground } \\
\text { (method } \\
\text { not indi- } \\
\text { cated) }\end{array}$ & Maceration & $\begin{array}{c}\text { acidified } \\
\text { Methanol } \\
\text { solution } \\
\text { (methanol } \\
\text { and } \\
1 \text { N hy- } \\
\text { drochloric } \\
\text { acid 85:15 } \\
v / v \text { ). }\end{array}$ & $1 \mathrm{~g} / 5 \mathrm{~mL}$ & $50{ }^{\circ} \mathrm{C}$ & N.I. & $30 \mathrm{~min}$ & 3 & $\begin{array}{l}\text { Centrifuged, } \\
\text { stored at } \\
-20^{\circ} \mathrm{C}\end{array}$ & $\begin{array}{l}\text { TPC, TFC, } \\
\text { and TMAC }\end{array}$ \\
\hline
\end{tabular}


Table 1. Cont.

\begin{tabular}{|c|c|c|c|c|c|c|c|c|c|c|c|c|c|c|}
\hline Author & Reference & Country & $\begin{array}{c}\text { Botanical } \\
\text { Origin }\end{array}$ & $\begin{array}{c}\text { Pre- } \\
\text { Extraction }\end{array}$ & $\begin{array}{c}\text { Pulve- } \\
\text { Risation }\end{array}$ & $\begin{array}{l}\text { Extraction } \\
\text { Method }\end{array}$ & Solvent & $\begin{array}{c}\text { Volume } \\
\text { of } \\
\text { Solvent }\end{array}$ & $\begin{array}{c}\text { Extraction } \\
\text { Tempe- } \\
\text { Rature }\end{array}$ & $\begin{array}{l}\text { Mixing/ } \\
\text { Power }\end{array}$ & $\begin{array}{l}\text { Extraction } \\
\text { Time }\end{array}$ & $\begin{array}{l}\text { No. of } \\
\text { Extrac- } \\
\text { tions }\end{array}$ & $\begin{array}{c}\text { Post- } \\
\text { Extraction }\end{array}$ & $\begin{array}{c}\text { Antioxidant } \\
\text { Assays }\end{array}$ \\
\hline $\begin{array}{l}\text { Zuluaga- } \\
\text { Domínguez, } \\
\text { Castro- } \\
\text { Mercado } \\
\text { et al., } 2019\end{array}$ & [92] & Colombia & $\begin{array}{l}\text { Hypochaeris } \\
\text { spp., and } \\
\text { Brassica spp. }\end{array}$ & $\begin{array}{l}\text { Stored at } \\
4{ }^{\circ} \mathrm{C}\end{array}$ & None & Agitation & $\begin{array}{c}96 \% \\
\text { Ethanol } \\
\text { (Aqueous) }\end{array}$ & $1 \mathrm{~g} / 30 \mathrm{~mL}$ & N.I. & $\begin{array}{l}\text { Low } \\
\text { speed }\end{array}$ & $24 \mathrm{~h}$ & 1 & $\begin{array}{c}\text { Filtered } \\
\text { using } 3 \\
\text { hw filter } \\
\text { paper and } \\
\text { volume } \\
\text { com- } \\
\text { pleted } \\
\text { quantita- } \\
\text { tively to } \\
100 \mathrm{~mL}\end{array}$ & $\begin{array}{c}\text { TPC, TFC, } \\
\text { Total } \\
\text { Carotenoids } \\
\text { FRAP, ABTS }\end{array}$ \\
\hline $\begin{array}{c}\text { Bujang, } \\
\text { Zakaria } \\
\text { et al., } 2021\end{array}$ & [93] & Malaysia & $\begin{array}{c}\text { Maize (Zea } \\
\text { mays L) }\end{array}$ & $\begin{array}{l}\text { Stored at } \\
-20^{\circ} \mathrm{C}\end{array}$ & Crushed & Sonication & $\begin{array}{c}70 \% \\
\text { Ethanol } \\
\text { (Aqueous) }\end{array}$ & $2 \mathrm{~g} / 15 \mathrm{~mL}$ & RT & None & $30 \mathrm{~min}$ & 1 & $\begin{array}{l}\text { Centrifuged, } \\
\text { filtered } \\
\text { using } \\
\text { Whatman } \\
\# 2 \\
\end{array}$ & $\begin{array}{c}\text { TPC, TFC, } \\
\text { DPPH }\end{array}$ \\
\hline $\begin{array}{c}\text { Yang, } \\
\text { Zhang } \\
\text { et al., } 2019\end{array}$ & [16] & China & Rose & N.I. & $\begin{array}{l}\text { Ball } \\
\text { milled }\end{array}$ & Sonication & $\begin{array}{c}70 \% \\
\text { Ethanol } \\
\text { (Aqueous) }\end{array}$ & $\begin{array}{l}50 \mathrm{mg} / \\
1 \mathrm{~mL}\end{array}$ & $25^{\circ} \mathrm{C}$ & $\begin{array}{c}600 \mathrm{~W} \\
\text { and a } \\
\text { fre- } \\
\text { quency } \\
\text { of } \\
20 \mathrm{kHz}\end{array}$ & $4 \mathrm{~h}$ & 1 & Filtered & $\begin{array}{c}\text { TFC, DPPH, } \\
\text { ORAC, } \\
\text { ABTS, In } \\
\text { Vivo } \\
\text { antioxidant }\end{array}$ \\
\hline $\begin{array}{l}\text { Kaskoniene, } \\
\text { Kaskonas } \\
\text { et al., } 2015\end{array}$ & [94] & Lithuania & multifloral & N.I. & None & Maceration & $\begin{array}{c}85 \% \\
\text { Methanol } \\
\text { (Aqueous) }\end{array}$ & N.I. & RT & N.I. & $24 \mathrm{~h}$ & 3 & Filtered & $\begin{array}{c}\text { TPC, TFC, } \\
\text { DPPH }\end{array}$ \\
\hline $\begin{array}{l}\text { Kaškonienè, } \\
\text { Katile- } \\
\text { vičiūtè } \\
\text { et al., } 2018\end{array}$ & [95] & Lithuania & multifloral & N.I. & None & Maceration & $\begin{array}{c}85 \% \\
\text { Methanol } \\
\text { (Aqueous) }\end{array}$ & N.I. & RT & N.I. & $24 \mathrm{~h}$ & 3 & Filtered & $\begin{array}{c}\text { TPC, TFC, } \\
\text { DPPH }\end{array}$ \\
\hline $\begin{array}{c}\text { Khider, } \\
\text { Elbanna } \\
\text { et al., } 2013\end{array}$ & [96] & Egypt & $\begin{array}{c}\text { Maize (Zea } \\
\text { mays), } \\
\text { clover } \\
\text { (Trifolium } \\
\text { alexandrinum), } \\
\text { and Date } \\
\text { palm (Phoenix } \\
\text { dactylifera) }\end{array}$ & $\begin{array}{l}\text { Stored at } \\
4{ }^{\circ} \mathrm{C}\end{array}$ & $\begin{array}{l}\text { Powdered } \\
\text { (method } \\
\text { not indi- } \\
\text { cated) }\end{array}$ & Maceration & Methanol & $\begin{array}{c}50 \mathrm{~g} / \\
500 \mathrm{~mL}\end{array}$ & RT & None & $12 \mathrm{~h}$ & 1 & $\begin{array}{c}\text { Filtered } \\
\text { using } \\
\text { Whatman } \\
\text { paper \# } 5\end{array}$ & $\mathrm{DPPH}$ \\
\hline
\end{tabular}


Table 1. Cont.

\begin{tabular}{|c|c|c|c|c|c|c|c|c|c|c|c|c|c|c|}
\hline Author & Reference & Country & $\begin{array}{c}\text { Botanical } \\
\text { Origin }\end{array}$ & $\begin{array}{c}\text { Pre- } \\
\text { Extraction }\end{array}$ & $\begin{array}{c}\text { Pulve- } \\
\text { Risation }\end{array}$ & $\begin{array}{l}\text { Extraction } \\
\text { Method }\end{array}$ & Solvent & $\begin{array}{l}\text { Volume } \\
\text { of } \\
\text { Solvent }\end{array}$ & $\begin{array}{l}\text { Extraction } \\
\text { Tempe- } \\
\text { Rature }\end{array}$ & $\begin{array}{l}\text { Mixing/ } \\
\text { Power }\end{array}$ & $\begin{array}{c}\text { Extraction } \\
\text { Time }\end{array}$ & $\begin{array}{l}\text { No. of } \\
\text { Extrac- } \\
\text { tions }\end{array}$ & $\begin{array}{c}\text { Post- } \\
\text { Extraction }\end{array}$ & $\begin{array}{l}\text { Antioxidant } \\
\text { Assays }\end{array}$ \\
\hline $\begin{array}{c}\text { Khider, } \\
\text { Elbanna } \\
\text { et al., } 2013\end{array}$ & [96] & Egypt & $\begin{array}{c}\text { Maize (Zea } \\
\text { mays), } \\
\text { clover } \\
\text { (Trifolium } \\
\text { alexandrinum), } \\
\text { and date } \\
\text { palm (Phoenix } \\
\text { dactylifera) } \\
\end{array}$ & $\begin{array}{l}\text { Stored at } \\
4{ }^{\circ} \mathrm{C}\end{array}$ & $\begin{array}{l}\text { Powdered } \\
\text { (method } \\
\text { not indi- } \\
\text { cated) }\end{array}$ & Maceration & Hexane & $\begin{array}{c}50 \mathrm{~g} / \\
500 \mathrm{~mL}\end{array}$ & RT & None & $12 \mathrm{~h}$ & 1 & $\begin{array}{c}\text { Filtered } \\
\text { using } \\
\text { Whatman } \\
\text { paper \# } 5\end{array}$ & $\mathrm{DPPH}$ \\
\hline $\begin{array}{c}\text { Freire, } \\
\text { Lins et al., } \\
2012\end{array}$ & [98] & Brazil. & multifloral & N.I. & None & Sonication & Ethanol & N.I. & N.I. & N.I. & N.I. & N.I. & $\begin{array}{c}\text { Filtered, } \\
\text { dried in } \\
\text { vacuo }\end{array}$ & $\begin{array}{l}\text { TPC, DPPH, } \\
\text { ABTS, Fe } \\
\text { Chelating } \\
\end{array}$ \\
\hline $\begin{array}{l}\text { Kim, Jo } \\
\text { et al., } 2015\end{array}$ & [99] & Korea & multifloral & $\begin{array}{c}\text { Dried at } \\
40^{\circ} \mathrm{C} \text { and } \\
\text { then stored } \\
\text { in a freezer } \\
\text { until use }\end{array}$ & None & Maceration & $\begin{array}{c}80 \% \\
\text { Methanol } \\
\text { (Aqueous) }\end{array}$ & N.I. & N.I. & N.I. & N.I. & 2 & N.I. & DPPH, TPC \\
\hline $\begin{array}{l}\text { Zhang, } \\
\text { Liu et al., } \\
2020\end{array}$ & [101] & China & $\begin{array}{c}\text { Rapeseed } \\
\text { (Brassica } \\
\text { campestris L.) }\end{array}$ & $\begin{array}{l}\text { Extracted } \\
\text { with } \\
\text { petroleum } \\
\text { ether to } \\
\text { remove the } \\
\text { lipids }\end{array}$ & $\begin{array}{l}\text { Powdered } \\
\text { (method } \\
\text { not indi- } \\
\text { cated) }\end{array}$ & Sonication & $\begin{array}{c}80 \% \\
\text { Ethanol } \\
\text { (Aqueous) }\end{array}$ & $50 \mathrm{~mL} / \mathrm{g}$ & $80^{\circ} \mathrm{C}$ & $40 \mathrm{kHz}$ & $30 \mathrm{~min}$ & 1 & $\begin{array}{l}\text { Dried in } \\
\text { vacuo, } \\
\text { lyophilised }\end{array}$ & $\begin{array}{l}\text { DPPH, } \\
\text { ABTS, } \\
\text { FRAP }\end{array}$ \\
\hline $\begin{array}{c}\text { Castagna, } \\
\text { Benelli } \\
\text { et al., } 2020\end{array}$ & [102] & Italy & Chestnut & N.I. & None & Sonication & $\begin{array}{c}80 \% \\
\text { Methanol } \\
\text { (Aqueous) }\end{array}$ & N.I. & $4^{\circ} \mathrm{C}$ & N.I. & $30 \mathrm{~min}$ & 1 & $\begin{array}{l}\text { Centrifuged } \\
\text { and } \\
\text { filtered } \\
\text { through } \\
0.45 \mu \mathrm{m} \\
\text { filter }\end{array}$ & TPC, TFC \\
\hline
\end{tabular}


Table 1. Cont.

\begin{tabular}{|c|c|c|c|c|c|c|c|c|c|c|c|c|c|c|}
\hline Author & Reference & Country & $\begin{array}{c}\text { Botanical } \\
\text { Origin }\end{array}$ & $\begin{array}{c}\text { Pre- } \\
\text { Extraction }\end{array}$ & $\begin{array}{c}\text { Pulve- } \\
\text { Risation }\end{array}$ & $\begin{array}{l}\text { Extraction } \\
\text { Method }\end{array}$ & Solvent & $\begin{array}{c}\begin{array}{c}\text { Volume } \\
\text { of } \\
\text { Solvent }\end{array} \\
\end{array}$ & $\begin{array}{c}\text { Extraction } \\
\text { Tempe- } \\
\text { Rature }\end{array}$ & $\begin{array}{l}\text { Mixing/ } \\
\text { Power }\end{array}$ & $\begin{array}{c}\text { Extraction } \\
\text { Time }\end{array}$ & $\begin{array}{c}\text { No. of } \\
\text { Extrac- } \\
\text { tions }\end{array}$ & $\begin{array}{c}\text { Post- } \\
\text { Extraction }\end{array}$ & $\begin{array}{c}\text { Antioxidant } \\
\text { Assays }\end{array}$ \\
\hline $\begin{array}{l}\text { Oyarzun, } \\
\text { Andia } \\
\text { et al., } 2020\end{array}$ & [103] & Chile & multifloral & N.I. & None & Sonication & Ethanol & $1.0 \mathrm{~g} \mathrm{in}$ & RT & $\begin{array}{l}37 \mathrm{kHz} \\
\text { fre- } \\
\text { quency } \\
\text { and } \\
240 \mathrm{~W}\end{array}$ & $10 \mathrm{~min}$ & 3 & $\begin{array}{c}\text { Centrifuged } \\
\text { and } \\
\text { filtered } \\
\text { through } \\
\text { Whatman } \\
\# 1\end{array}$ & $\begin{array}{c}\text { FRAP, } \\
\text { ORAC, TPC, } \\
\text { TFC }\end{array}$ \\
\hline $\begin{array}{c}\text { Asmae, } \\
\text { Nawal } \\
\text { et al., } 2021\end{array}$ & [104] & Morocco & multifloral & $\begin{array}{l}\text { Stored at } \\
-20^{\circ} \mathrm{C}\end{array}$ & None & Maceration & $\begin{array}{c}70 \% \\
\text { Ethanol } \\
\text { (Aqueous) }\end{array}$ & $\begin{array}{l}1.0 \mathrm{~g} \mathrm{in} \\
10 \mathrm{~mL}\end{array}$ & RT & N.I. & 1 week & 1 & $\begin{array}{c}\text { Filtered } \\
\text { through } \\
\text { Whatman } \\
\# 1\end{array}$ & $\begin{array}{c}\text { TPC, } \\
\text { Flavones } \\
\text { and } \\
\text { Flavonols } \\
\text { Content, } \\
\text { TAC, DPPH, } \\
\text { RP, ABTS }\end{array}$ \\
\hline $\begin{array}{c}\text { Feas, } \\
\text { Vazquez- } \\
\text { Tato et al., } \\
2012\end{array}$ & [6] & Portugal & multifloral & N.I. & $\begin{array}{l}\text { Ground } \\
\text { (method } \\
\text { not indi- } \\
\text { cated) }\end{array}$ & $\begin{array}{l}\text { Sonication } \\
\text { and } \\
\text { maceration }\end{array}$ & Methanol & $1: 2$ & RT & N.I. & $\begin{array}{l}30 \text { min } \\
\text { and } 2 \\
\text { days }\end{array}$ & 1 & $\begin{array}{l}\text { Centrifuged, } \\
\text { dried in } \\
\text { vacuo }\end{array}$ & $\begin{array}{c}\text { TPC, TFC, } \\
\text { DPPH, } \\
\text { B-Carotene } \\
\text { Bleaching } \\
\end{array}$ \\
\hline $\begin{array}{l}\text { Rodriguez- } \\
\text { Gonzalez, } \\
\text { Ortega- } \\
\text { Toro et al., } \\
2018 \\
\end{array}$ & [105] & Colombia & multifloral & N.I. & None & $\begin{array}{l}\text { Microwave } \\
\text { Assisted } \\
\text { Extraction }\end{array}$ & Ethanol & $\begin{array}{c}1 \mathrm{~g} / 10 \\
\text { or } \\
50 \mathrm{~mL}\end{array}$ & Varies & $\begin{array}{c}1350 \mathrm{~W} \\
\text { of } \\
\text { power } \\
\text { and } \\
60 \mathrm{~Hz}\end{array}$ & $\begin{array}{c}6,12 \text { and } \\
24 \mathrm{~s}\end{array}$ & 1 & $\begin{array}{l}\text { Filtered } \\
\text { and } \\
\text { stored in } \\
-20^{\circ} \mathrm{C}\end{array}$ & $\begin{array}{c}\text { TPC, ABTS, } \\
\text { FRAP }\end{array}$ \\
\hline $\begin{array}{l}\text { Rodriguez- } \\
\text { Gonzalez, } \\
\text { Ortega- } \\
\text { Toro et al., } \\
2018\end{array}$ & [105] & Colombia & multifloral & N.I. & None & Sonication & Ethanol & $1 \mathrm{~g} / 10 \mathrm{~mL}$ & N.I. & $\begin{array}{l}5 \mathrm{kHz} \\
\text { fre- } \\
\text { quency } \\
\text { and } \\
250 \mathrm{~W}\end{array}$ & $15 \mathrm{~min}$ & 1 & $\begin{array}{l}\text { Filtered } \\
\text { and } \\
\text { stored in } \\
-20^{\circ} \mathrm{C}\end{array}$ & $\begin{array}{c}\text { TPC, ABTS, } \\
\text { FRAP }\end{array}$ \\
\hline
\end{tabular}


Table 1. Cont.

\begin{tabular}{|c|c|c|c|c|c|c|c|c|c|c|c|c|c|c|}
\hline Author & Reference & Country & $\begin{array}{c}\text { Botanical } \\
\text { Origin }\end{array}$ & $\begin{array}{c}\text { Pre- } \\
\text { Extraction }\end{array}$ & $\begin{array}{c}\text { Pulve- } \\
\text { Risation }\end{array}$ & $\begin{array}{l}\text { Extraction } \\
\text { Method }\end{array}$ & Solvent & $\begin{array}{c}\begin{array}{c}\text { Volume } \\
\text { of } \\
\text { Solvent }\end{array} \\
\text {. }\end{array}$ & $\begin{array}{c}\text { Extraction } \\
\text { Tempe- } \\
\text { Rature }\end{array}$ & $\begin{array}{l}\text { Mixing/ } \\
\text { Power }\end{array}$ & $\begin{array}{c}\text { Extraction } \\
\text { Time }\end{array}$ & $\begin{array}{l}\text { No. of } \\
\text { Extrac- } \\
\text { tions }\end{array}$ & $\begin{array}{c}\text { Post- } \\
\text { Extraction }\end{array}$ & $\begin{array}{l}\text { Antioxidant } \\
\text { Assays }\end{array}$ \\
\hline $\begin{array}{l}\text { Velasquez, } \\
\text { Rodriguez } \\
\text { et al., } 2017\end{array}$ & [106] & Chile & multifloral & N.I. & None & Sonication & Water & $1: 1$ & N.I. & N.I. & $1 \mathrm{~h}$ & 5 & $\begin{array}{c}\text { Filtered } \\
\text { using } \\
\text { Whatman } \\
\text { \#2 dried } \\
\text { in vacuo } \\
\text { and the } \\
\text { dry } \\
\text { extract } \\
\text { was recon- } \\
\text { stituted to } \\
10 \mathrm{~mL}, \\
\text { filtered } \\
\text { (EDLAB } \\
\text { CA } \\
\text { syringe } \\
\text { filter 0.45 } \\
\mu \mathrm{m} \text { ) and } \\
\text { stored at } \\
-20^{\circ} \mathrm{C} \text {. }\end{array}$ & $\begin{array}{c}\text { Total } \\
\text { Carotenoid, } \\
\text { TPC, FRAP }\end{array}$ \\
\hline $\begin{array}{c}\text { Carpes, } \\
\text { de } \\
\text { Alencar } \\
\text { et al., } 2013\end{array}$ & [107] & Brazil & multifloral & N.I. & None & Maceration & $\begin{array}{c}70 \% \\
\text { Ethanol } \\
\text { (Aqueous) }\end{array}$ & $1: 1$ & $70^{\circ} \mathrm{C}$ & N.I. & $30 \mathrm{~min}$ & N.I. & N.I. & $\begin{array}{c}\text { TPC, TFC, } \\
\text { DPPH, } \\
\text { Antioxidant } \\
\text { activity by } \\
\text { the coupled } \\
\text { oxidation of } \\
\text { b-carotene } \\
\text { and linoleic } \\
\text { acid }\end{array}$ \\
\hline $\begin{array}{l}\text { Santa } \\
\text { Bárbara, } \\
\text { Moreira } \\
\text { et al., } 2020\end{array}$ & [108] & Brazil & multifloral & $\begin{array}{l}\text { Oven dried, } \\
\text { freeze dried, } \\
\text { fresh }\end{array}$ & None & Agitation & $\begin{array}{c}70 \% \\
\text { Ethanol } \\
\text { (Aqueous) }\end{array}$ & $\begin{array}{c}10 \mathrm{~g} / \\
50 \mathrm{~mL}\end{array}$ & RT & N.I. & $45 \mathrm{~min}$ & 1 & $\begin{array}{l}\text { Filtered, } \\
\text { Dried in } \\
\text { vacuo }\end{array}$ & $\begin{array}{c}\text { b-Carotene } \\
\text { bleaching } \\
\text { assay, FRAP } \\
\text { DPPH, TPC, } \\
\text { TFC }\end{array}$ \\
\hline $\begin{array}{c}\text { Carpes, } \\
\text { Begnini } \\
\text { et al., } 2007\end{array}$ & [109] & Brazil & multifloral & N.I. & Milled & Agitation & $\begin{array}{c}40 \% \\
\text { Ethanol } \\
\text { (Aqueous) }\end{array}$ & $\begin{array}{l}2.0 \mathrm{~g} / \\
15 \mathrm{~mL}\end{array}$ & $70^{\circ} \mathrm{C}$ & N.I. & $30 \mathrm{~min}$ & 2 & $\begin{array}{l}\text { Stored at } \\
5^{\circ} \mathrm{C}\end{array}$ & $\begin{array}{c}\text { oxidation of } \\
\text {-carotene } \\
\text { and linoleic } \\
\text { acid, } \\
\text { TPC }\end{array}$ \\
\hline
\end{tabular}


Table 1. Cont.

\begin{tabular}{|c|c|c|c|c|c|c|c|c|c|c|c|c|c|c|}
\hline Author & Reference & Country & $\begin{array}{c}\text { Botanical } \\
\text { Origin }\end{array}$ & $\begin{array}{c}\text { Pre- } \\
\text { Extraction }\end{array}$ & $\begin{array}{c}\text { Pulve- } \\
\text { Risation }\end{array}$ & $\begin{array}{l}\text { Extraction } \\
\text { Method }\end{array}$ & Solvent & $\begin{array}{c}\begin{array}{c}\text { Volume } \\
\text { of } \\
\text { Solvent }\end{array} \\
\end{array}$ & $\begin{array}{c}\text { Extraction } \\
\text { Tempe- } \\
\text { Rature }\end{array}$ & $\begin{array}{l}\text { Mixing/ } \\
\text { Power }\end{array}$ & $\begin{array}{l}\text { Extraction } \\
\text { Time }\end{array}$ & $\begin{array}{l}\text { No. of } \\
\text { Extrac- } \\
\text { tions }\end{array}$ & $\begin{array}{c}\text { Post- } \\
\text { Extraction }\end{array}$ & $\begin{array}{l}\text { Antioxidant } \\
\text { Assays }\end{array}$ \\
\hline $\begin{array}{c}\text { Carpes, } \\
\text { Begnini } \\
\text { et al., } 2007\end{array}$ & [109] & Brazil & multifloral & N.I. & Milled & Agitation & $\begin{array}{c}50 \% \\
\text { Ethanol } \\
\text { (Aqueous) }\end{array}$ & $\begin{array}{l}2.0 \mathrm{~g} / \\
15 \mathrm{~mL}\end{array}$ & $70^{\circ} \mathrm{C}$ & N.I. & $30 \mathrm{~min}$ & 2 & $\begin{array}{l}\text { Stored at } \\
5^{\circ} \mathrm{C}\end{array}$ & $\begin{array}{l}\text { oxidation of } \\
\text {-carotene } \\
\text { and linoleic } \\
\text { acid, TPC }\end{array}$ \\
\hline $\begin{array}{c}\text { Carpes, } \\
\text { Begnini } \\
\text { et al., } 2007\end{array}$ & [109] & Brazil & multifloral & N.I. & Milled & Agitation & $\begin{array}{c}60 \% \\
\text { Ethanol } \\
\text { (Aqueous) }\end{array}$ & $\begin{array}{l}2.0 \mathrm{~g} / \\
15 \mathrm{~mL}\end{array}$ & $70^{\circ} \mathrm{C}$ & N.I. & $30 \mathrm{~min}$ & 2 & $\begin{array}{l}\text { Stored at } \\
5^{\circ} \mathrm{C}\end{array}$ & $\begin{array}{l}\text { oxidation of } \\
\text {-carotene } \\
\text { and linoleic } \\
\text { acid, TPC }\end{array}$ \\
\hline $\begin{array}{c}\text { Carpes, } \\
\text { Begnini } \\
\text { et al., } 2007\end{array}$ & [109] & Brazil & multifloral & N.I. & Milled & Agitation & $\begin{array}{c}70 \% \\
\text { Ethanol } \\
\text { (Aqueous) }\end{array}$ & $\begin{array}{l}2.0 \mathrm{~g} / \\
15 \mathrm{~mL}\end{array}$ & $70^{\circ} \mathrm{C}$ & N.I. & $30 \mathrm{~min}$ & 2 & $\begin{array}{l}\text { Stored at } \\
5^{\circ} \mathrm{C}\end{array}$ & $\begin{array}{l}\text { oxidation of } \\
\text {-carotene } \\
\text { and linoleic } \\
\text { acid, TPC }\end{array}$ \\
\hline $\begin{array}{c}\text { Carpes, } \\
\text { Begnini } \\
\text { et al., } 2007\end{array}$ & [109] & Brazil & multifloral & N.I. & Milled & Agitation & $\begin{array}{c}80 \% \\
\text { Ethanol } \\
\text { (Aqueous) }\end{array}$ & $\begin{array}{l}2.0 \mathrm{~g} / \\
15 \mathrm{~mL}\end{array}$ & $70^{\circ} \mathrm{C}$ & N.I. & $30 \mathrm{~min}$ & 2 & $\begin{array}{l}\text { Stored at } \\
5^{\circ} \mathrm{C}\end{array}$ & $\begin{array}{l}\text { oxidation of } \\
\text {-carotene } \\
\text { and linoleic } \\
\text { acid, TPC }\end{array}$ \\
\hline $\begin{array}{c}\text { Carpes, } \\
\text { Begnini } \\
\text { et al., } 2007\end{array}$ & [109] & Brazil & multifloral & N.I. & Milled & Agitation & $\begin{array}{c}90 \% \\
\text { Ethanol } \\
\text { (Aqueous) }\end{array}$ & $\begin{array}{l}2.0 \mathrm{~g} / \\
15 \mathrm{~mL}\end{array}$ & $70^{\circ} \mathrm{C}$ & N.I. & $30 \mathrm{~min}$ & 2 & $\begin{array}{l}\text { Stored at } \\
5^{\circ} \mathrm{C}\end{array}$ & $\begin{array}{l}\text { oxidation of } \\
\text {-carotene } \\
\text { and linoleic } \\
\text { acid, TPC }\end{array}$ \\
\hline $\begin{array}{l}\text { Zou, Hu } \\
\text { et al., } 2020\end{array}$ & [110] & $\begin{array}{l}\text { South } \\
\text { Korea, } \\
\text { China }\end{array}$ & multifloral & N.I. & None & Maceration & $\begin{array}{c}70 \% \\
\text { Ethanol } \\
\text { (Aqueous) }\end{array}$ & N.I. & RT & N.I. & $48 \mathrm{~h}$ & 3 & $\begin{array}{l}\text { Filtered, } \\
\text { dried in } \\
\text { vacuo }\end{array}$ & $\begin{array}{l}\text { TPC, TFC, } \\
\text { DPPH }\end{array}$ \\
\hline $\begin{array}{l}\text { Paradowska, } \\
\text { Zielińska } \\
\text { et al., } 2017\end{array}$ & [111] & Poland & $\begin{array}{l}\text { Buckwheat, } \\
\text { Oilseeed Rape }\end{array}$ & N.I. & None & Sonication & $\begin{array}{c}80 \% \\
\text { Methanol } \\
\text { (Aqueous) }\end{array}$ & $\begin{array}{c}0.2 / \\
10 \mathrm{~mL}\end{array}$ & $25^{\circ} \mathrm{C}$ & N.I. & N.I. & 1 & $\begin{array}{l}\text { Filtered } \\
\text { through a } \\
\text { sintered } \\
\text { glass filter } \\
\text { funnel }\end{array}$ & $\begin{array}{c}\text { TPC, TFC, } \\
\text { DPPH, } \\
\text { FRAP, } \\
\text { ORAC }\end{array}$ \\
\hline $\begin{array}{c}\text { Yildiz, } \\
\text { Karahalil } \\
\text { et al., } 2014\end{array}$ & [112] & Turkey & multifloral & N.I. & None & Suspension & Water & N.I. & N.I. & N.I. & N.I. & N.I. & Filtered & TPC, FRAP \\
\hline $\begin{array}{c}\text { Silva, } \\
\text { Camara } \\
\text { et al., } 2009\end{array}$ & [113] & Brazil & multifloral & N.I. & None & Sonication & Ethanol & N.I. & N.I. & N.I. & N.I. & N.I. & $\begin{array}{c}\text { Filtered, } \\
\text { dried in } \\
\text { vacuo }\end{array}$ & $\mathrm{DPPH}$ \\
\hline
\end{tabular}


Table 1. Cont.

\begin{tabular}{|c|c|c|c|c|c|c|c|c|c|c|c|c|c|c|}
\hline Author & Reference & Country & $\begin{array}{c}\text { Botanical } \\
\text { Origin }\end{array}$ & $\begin{array}{c}\text { Pre- } \\
\text { Extraction }\end{array}$ & $\begin{array}{l}\text { Pulve- } \\
\text { Risation }\end{array}$ & $\begin{array}{l}\text { Extraction } \\
\text { Method }\end{array}$ & Solvent & $\begin{array}{l}\text { Volume } \\
\text { of } \\
\text { Solvent }\end{array}$ & $\begin{array}{c}\text { Extraction } \\
\text { Tempe- } \\
\text { Rature }\end{array}$ & $\begin{array}{c}\text { Mixing/ } \\
\text { Power }\end{array}$ & $\begin{array}{l}\text { Extraction } \\
\text { Time }\end{array}$ & $\begin{array}{l}\text { No. of } \\
\text { Extrac- } \\
\text { tions }\end{array}$ & $\begin{array}{c}\text { Post- } \\
\text { Extraction }\end{array}$ & $\begin{array}{c}\text { Antioxidant } \\
\text { Assays }\end{array}$ \\
\hline $\begin{array}{l}\text { Dai, Ding } \\
\text { et al., } 2013\end{array}$ & [114] & China & $\begin{array}{c}\text { Rape, Rose, } \\
\text { Camellia, } \\
\text { Herba leonuri } \\
\text { and } \\
\text { Schizandra }\end{array}$ & N.I. & None & Sonication & Ethanol & $\begin{array}{l}50 \mathrm{mg} / \\
10 \mathrm{~mL}\end{array}$ & N.I. & N.I. & N.I. & N.I. & $\begin{array}{l}\text { Filtered, } \\
\text { com- } \\
\text { pleted to } \\
10 \mathrm{~mL}\end{array}$ & TPC, DPPH \\
\hline $\begin{array}{c}\text { Amalia, } \\
\text { Diantini } \\
\text { et al., } 2020\end{array}$ & [115] & Indonesia & multifloral & N.I. & None & Suspension & Water & $1: 10$ & N.I. & N.I. & N.I. & N.I. & $\begin{array}{c}\text { Filtered } \\
\text { using } \\
\text { Whatman } \\
\text { \# } 41 \text { paper, } \\
\text { freeze- } \\
\text { dried }\end{array}$ & DPPH \\
\hline
\end{tabular}

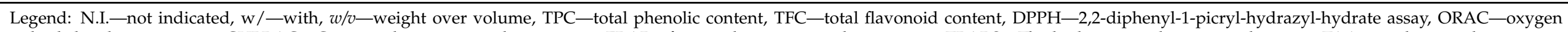

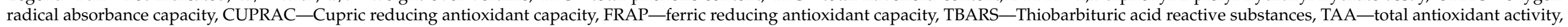

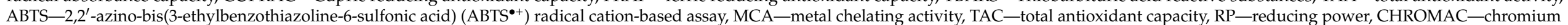
reducing antioxidant capacity. 
It can be assumed that the adopted extraction process for a bee pollen sample, including the sample pre-treatment, extraction method and solvent, impacts the extraction efficiency of antioxidant constituents and consequently on the level of antioxidant activity measured. The objective of this study was to use the Design of Experiment approach to optimise an extraction process for bee pollen with a view to maximising the extraction of antioxidant constituents as measured by the DPPH, FRAP and TPC assays. The independent variables were sample pulverisation, extraction process (agitation, maceration, reflux or sonication) and extraction solvent (methanol, 70\% aqueous ethanol, ethanol or water). Two different bee pollen samples from western Australia, Jarrah (Eucalyptus marginata) and Marri (Corymbia calophylla) bee pollen, were used as model bee pollen samples.

\section{Materials and Methods}

\subsection{Chemicals, Reagents and Pollen Samples}

The chemicals and reagents were sourced as follows: Folin and Ciocalteu's phenol reagent 2N, (F9252-1L, Lot No. SHBH4781V), 2,4,6-tris(2-pyridyl)-1,3,5-triazine (TPTZ $\geq 98.0 \%$, Lot No. BCBW0518, CAS No. 3682-35-7), iron (III) chloride hexahydrate $\left(\mathrm{FeCl}_{3} \cdot 6 \mathrm{H}_{2} \mathrm{O}\right.$ ACS Reagent 97.0\%, Lot No. BCBZ5998, CAS No. 10025-77-1), iron (II) sulphate heptahydrate $\left(\mathrm{FeSO}_{4} \cdot 7 \mathrm{H}_{2} \mathrm{O}\right.$ ACS reagent, $\geq 99.0 \%$, Lot No. MKCJ9113, CAS No. 7782-63-0), fructose $\left(\mathrm{C}_{6} \mathrm{H}_{12} \mathrm{O}_{6} \geq 99.0 \%\right.$, Lot No. SLBZ1343, CAS No. 57-48-7), and maltose $\left(\mathrm{C}_{12} \mathrm{H}_{22} \mathrm{O}_{11} \cdot \mathrm{H}_{2} \mathrm{O}\right.$ BioXtra, $\geq 99 \%$, Lot No. SLCC4130, CAS No. 6363-53-7) from Sigma Aldrich Truganina, Victoria 3029 Australia.; sodium anhydrous carbonate $\left(\mathrm{Na}_{2} \mathrm{CO}_{3}\right.$, LR, B.N. 334280, CA No. 497-19-8), glucose (D-glucose anhydrous, $\mathrm{C}_{6} \mathrm{H}_{12} \mathrm{O}_{6}$ $99.0 \%$, Batch No. 314615, CAS No. 50-99-7) sucrose $\left(\mathrm{C}_{12} \mathrm{H}_{22} \mathrm{O}_{11} 99.0 \%\right.$, Batch No. 324472, CAS No. 57-50-1), ethanol $\left(\mathrm{CH}_{3} \mathrm{CH}_{2} \mathrm{OH}\right.$, B.N. 360221, 64-17-5), from Chem Supply, Port Adelaide, SA 5015, Australia; anhydrous sodium acetate $\left(\mathrm{C}_{2} \mathrm{H}_{3} \mathrm{NaO}_{2} \geq 99.0 \%\right.$, Batch No. AF512004, CAS No. 127-09-3) and glacial acetic acid $\geq 99.0 \%$, Batch No. AH602167, CAS No.64-19-7) were purchased from Ajax Finechem, Wollongong NSW 2500, Australia; hydrochloric acid (HCl, Pt. 3350-1813, CAS No. 7647-01-0) was obtained from Asia Pacific Specialty Chemicals Limited, Seven Hills NSW 2147, Australia; 2,2-diphenyl1-picrylhydrazyl $\left(\mathrm{C}_{18} \mathrm{H}_{12} \mathrm{~N}_{5} \mathrm{O}_{6}\right.$, CAS No. 1898-66-4 was purchased from Fluka AG, Buchs, Sankt Gallen, Switzerland; trihydroxybenzoic acid $\left(\mathrm{C}_{7} \mathrm{H}_{6} \mathrm{O}_{5}\right.$, Lot. No. 1278, CAS No. 149-91-7) from Ajax Chemicals Ltd.; Sydney-Melbourne; Methanol $\left(\mathrm{CH}_{3} \mathrm{OH}, \mathrm{B} . \mathrm{N}\right.$. 19758725, 67-56-1) from Scharlau, Barcelona, Spain.

Jarrah (Eucalyptus marginata) and Marri (Corymbia calophylla) pollen, both harvested in October 2019, were purchased from Davies Apiaries in Oldbury, 6121, WA, Australia.

\subsection{Extract Preparation}

The bee pollen samples had already been dried, processed, and packed commercially, and no further treatment was undertaken prior to their analysis. To obtain pulverised samples $(75-150 \mu \mathrm{m})$, the crude pollen grains were milled for $5 \mathrm{~min}$ using a commercial grinder (Breville Coffee Grinder Model BCG200). An amount of $0.5 \mathrm{~g}$ of pollen samples (crude, and non-pulverised) were separately extracted using ethanol, methanol, deionised water, and 70\% ethanol in water, and the following extraction procedures:

Agitation. Agitation extraction was performed based on a protocol reported by Aleksieva et al. [72] with minor modifications. The extraction was carried out over $2 \mathrm{~h}$ in $7 \mathrm{~mL}$ of solvent using a hotplate magnetic stirrer (LLG Uni stirrer 3, John Morris Group) operating at a speed of $1500 \mathrm{rpm}$, with the temperature set at $40^{\circ} \mathrm{C}$. After $2 \mathrm{~h}$, the solvent was decanted, and was replaced with fresh solvent and the extraction process was repeated two more times for the sample.

Maceration. Maceration extraction was performed based on a protocol reported by Kaškonienè et al. [95] with minor modifications. The bee pollen sample was macerated in $7 \mathrm{~mL}$ of extraction solvent at room temperature $\left(25^{\circ} \mathrm{C}\right)$ at a speed of $160 \mathrm{rpm}$ shaking (Memmert Shaker Bath, Model WNB 22) over three days and solvent changes every $24 \mathrm{~h}$. 
Reflux. Reflux extraction was performed using an Electromantle reflux set-up and the protocol reported by Cheng et al. [81] with slight modifications. The method employed $21 \mathrm{~mL}$ of solvent and an extraction temperature determined by the boiling point of the respective solvent. Extraction was performed once over $2 \mathrm{~h}$ for each sample.

Sonication. Sonication extraction was performed following a procedure developed by Yan et al. [79] with slight modifications. The extraction was performed with $21 \mathrm{~mL}$ of solvent using a probe sonicator (Sonics Vibra Cell Model VCX130) operating at 130 Watts and $20 \mathrm{kHz}$. The amplitude was set at $100 \%$ and the extraction process was carried out once for $30 \mathrm{~min}$ on an ice bath.

Following extraction, the solvent was filtered (Whatman \#4 filter paper) and, if the extraction process was repeated, filtrates were combined, and made up to $25 \mathrm{~mL}$ with the respective solvent. The resulting solutions were stored at $-85^{\circ} \mathrm{C}$ until further analysis. Every extraction process was carried out in triplicate for each pollen sample, and the responses combined to determine the mean. Table 2 summarises the independent variables studied along with their corresponding abbreviations.

Table 2. Independent variables used in the Design of Experiments to optimise the extraction of bee pollen for antioxidant evaluation.

\begin{tabular}{ccc}
\hline Factors & Tested Conditions & Abbreviation \\
\hline Pulverisation & Crude, non-pulverised & - \\
& Pulverised & + \\
Solvent & $70 \%$ Ethanol & E70:30 \\
& Ethanol & EtOH \\
& Methanol & $\mathrm{MtOH}$ \\
Extraction Process & Water & $\mathrm{H}_{2} \mathrm{O}$ \\
& Agitation & $\mathrm{A}$ \\
& Maceration & $\mathrm{M}$ \\
& Reflux & $\mathrm{R}$ \\
& Sonication & $\mathrm{S}$ \\
\hline
\end{tabular}

\subsection{Determination of Total Phenolic Content}

A sugar solution was used as a blank in order to account for the potential sugar matrix interference in the assay. The sugar solution was prepared by diluting $2 \mathrm{~g}$ of a sugar stock solution (21.625 g of fructose, $18.125 \mathrm{~g}$ of glucose, $1.000 \mathrm{~g}$ of maltose, $0.750 \mathrm{~g}$ of sucrose and $8.500 \mathrm{~g}$ of water) to $5 \mathrm{~mL}$ ( $40 \%$ ) with deionised water. The solution was stored under refrigeration and used within a week. A dilute Folin-Ciocalteu reagent was prepared by mixing $1 \mathrm{~mL}$ of Folin-Ciocalteu reagent with $30 \mathrm{~mL}$ deionised water. A $0.75 \%$ anhydrous sodium carbonate solution was prepared by mixing $0.1875 \mathrm{~g} \mathrm{Na}_{2} \mathrm{CO}_{3}$ in $25 \mathrm{~mL}$ water. A $2 \mathrm{mg} / \mathrm{mL}$ gallic acid stock solution was prepared by dissolving $200 \mathrm{mg}$ of gallic acid in $100 \mathrm{~mL}$ deionised water and standards ranging in concentration from $0.18 \mathrm{mg} / \mathrm{mL}$ to $0.06 \mathrm{mg} / \mathrm{mL}$ were prepared by diluting the stock with water.

The TPC assay was performed based on the methodology described by Liberato et al. [116] with minor modifications. In brief, for the analysis, $200 \mu \mathrm{L}$ of pollen extract or $100 \mu \mathrm{L}$ of gallic acid standard spiked with $100 \mu \mathrm{L}$ of sugar solution were placed in a test tube followed by the addition of $1 \mathrm{~mL}$ of the diluted Folin-Ciocalteu reagent. The mixture was allowed to react for $5 \mathrm{~min}$ before $800 \mu \mathrm{L}$ of $\mathrm{Na}_{2} \mathrm{CO}_{3}$ was added. The mixture was kept in the dark for $2 \mathrm{~h}$ before the absorbance was measured at $760 \mathrm{~nm}$ (Carry 60 Bio UV-Vis spectrophotometer) using $100 \mu \mathrm{L}$ of water spiked with $100 \mu \mathrm{L}$ of sugar solution along with other TPC reagents as a blank. The analysis was carried out in triplicate and the mean results for each sample were obtained. The antioxidant activity was expressed as mg of gallic acid equivalent (GAE) per $\mathrm{g}$ of pollen.

TPC Value of Sample $(\mathrm{mg})$ Gallic Acid $=\frac{(\Delta \mathrm{Abs}-\text { intercept })}{\text { slope }} \times$ Dilution Factor 


\subsection{Determination of Antioxidant Activity using Ferric Reducing Antioxidant Power (FRAP) Assay}

The FRAP reagent was prepared by mixing in proportions of 1:1:10 $(v / v / v) 10 \mathrm{mM}$ TPTZ ( $0.31 \mathrm{~g}$ dissolved in $100 \mathrm{~mL}$ of $40 \mathrm{mM} \mathrm{HCl}), 20 \mathrm{mM} \mathrm{FeCl}_{3} \cdot 6 \mathrm{H}_{2} \mathrm{O}(0.5406 \mathrm{~g}$ dissolved in $100 \mathrm{~mL}$ of deionised water) and $300 \mathrm{mM}$ acetate buffer $\mathrm{pH} 3.6\left(3.1 \mathrm{~g} \mathrm{C}_{2} \mathrm{H}_{3} \mathrm{NaO}_{2}, 16.00 \mathrm{~mL}\right.$ of glacial acetic acid dissolved in $1000 \mathrm{~mL}$ of deionised water). The reagent was freshly prepared and incubated at $37{ }^{\circ} \mathrm{C}$ prior to each test. For the standard curve, a $2 \mathrm{mM}$ stock solution of $\mathrm{FeSO}_{4} \cdot 7 \mathrm{H}_{2} \mathrm{O}$ was prepared by dissolving $55.6 \mathrm{mg}$ of $\mathrm{FeSO}_{4} \cdot 7 \mathrm{H}_{2} \mathrm{O}$ in $100 \mathrm{~mL}$ of deionised water. Standards ranging in concentration from $1200 \mu \mathrm{M}$ to $200 \mu \mathrm{M}$ were prepared prior to each experiment, stored on ice, and used within $2 \mathrm{~h}$. The standard at $600 \mu \mathrm{M}$ was used as a positive control in each experiment.

The FRAP assay, which is based on the reduction of ferric 2,4,6-tris(2-pyridyl)-1,3,5triazine [Fe(III)-TPTZ] to ferrous complex at low $\mathrm{pH}$ followed by a spectrophotometric analysis, was performed according to the protocol described by Almeida et al. [60] with minor modifications. In brief, $20 \mu \mathrm{L}$ of pollen extract or standards were mixed with $180 \mu \mathrm{L}$ of FRAP reagent in a 96-well microplate, incubated at $37^{\circ} \mathrm{C}$ for $30 \mathrm{~min}$ and the absorbance of the reaction mixture was determined at $620 \mathrm{~nm}$ (BMG Labtech POLARstar Optima Microplate Reader). The mean of triplicate analysis results was calculated and the FRAP activity was determined on the interpolation of the standard curve and expressed as $\mu \mathrm{mol}$ $\mathrm{Fe}^{2+}$ equivalent $\left(\mathrm{Fe}^{+2} \mathrm{E}\right) / \mathrm{g} \mathrm{FW}$ of pollen.

$$
\text { FRAP Value of Sample }(\mu \mathrm{M}) \mathrm{Fe}(\mathrm{II})=\frac{(\Delta \text { Abs }- \text { intercept })}{\text { slope }} \times \text { Dilution Factor }
$$

\subsection{Determination of Antioxidant Activity using the 2,2-diphenyl-1-picrylhydrazyl (DPPH) Radical Scavenging Assay}

This colorimetric assay utilises 2,2-diphenyl-1-picrylhydrazyl (DPPH) radicals, which are purple in colour; the colour decays in the presence of antioxidant agents, seen in a change in absorbance at $517 \mathrm{~nm}$. The DPPH reaction mixture was made up of $0.130 \mathrm{mM}$ DPPH reagent (5.1262 mg of DPPH in $100 \mathrm{~mL}$ of methanol), $100 \mathrm{mM} \mathrm{NaC}{ }_{2} \mathrm{H}_{3} \mathrm{O}_{2}$ buffer pH 5.5 (7.355 g of $\mathrm{NaC}_{2} \mathrm{H}_{3} \mathrm{O}_{2}$ and $0.621 \mathrm{~g}$ of $\mathrm{HC}_{2} \mathrm{H}_{3} \mathrm{O}_{2}$ ) and bee pollen extract. Trolox in a concentration range of $600-100 \mu \mathrm{M}$ (aqueous, $\mathrm{pH}$ adjusted to $\mathrm{pH} 7.0$ to completely solubilize in water) was used as the standard, with the $400 \mu \mathrm{M}$ standard acting as a positive control throughout all tests.

The DPPH assay adopted in this experiment is based on the protocol described by Karabagias et al. [117] with minor modifications. In brief, $10 \mu \mathrm{L}$ of bee pollen extract or Trolox standards were placed in a 96-well microplate, followed by the addition of $100 \mu \mathrm{L}$ of $\mathrm{NaC}_{2} \mathrm{H}_{3} \mathrm{O}_{2}$ buffer and $190 \mu \mathrm{L}$ of $0.130 \mathrm{mM}$ methanolic DPPH solution. The reaction mixture was kept in the dark for 120 min before the absorbance was measured at $520 \mathrm{~nm}$ using the microplate reader. The mean radical scavenging activity of triplicate samples was expressed as the Trolox equivalent (TE), calculated by a linear regression analysis, and then expressed as $\mu \mathrm{mol}$ Trolox equivalent per $\mathrm{g}$ of pollen.

$$
\text { DPPH Value of Sample }(\mu \mathrm{M}) \text { Trolox }=\frac{(\Delta \text { Abs }- \text { intercept })}{\text { slope }} \times \text { Dilution Factor }
$$

\subsection{Statistical Analysis}

Statistical analysis of the data was carried out using Design Expert 12 (StatEase Inc., Minneapolis, MN, USA) and two-way t-test or one-way ANOVA was analysed using Graphpad Prism 9 (GraphPad Software, San Diego, CA, USA). Pareto plots of regression coefficients of the independent variables were generated using Microsoft Excel. The signal to noise ratio was set at 5 times the standard deviation of observations for each response $(n=3)$. The model was developed based on the regression analysis of the statistical significance of variables, and the model coefficient was significant when the $F$ value was larger than the critical $F$ value $(p<0.05)$. The relative influence of factors was identified by 
comparing the magnitude of regression coefficients. Correlations between responses were established using Spearman regression analysis. When significant interactions between factors were identified, a two-way $t$-test or a one-way analysis of variance with Tukey's post hoc comparison was used to identify differences between the groups, and the statistical significance was set at $p>0.05$.

\section{Results}

A thorough literature review of 101 published articles on the most widely used conditions for extracting antioxidant principles from bee pollen (Table 1) indicated a lack of a consistent approach. Researchers used a variety of antioxidant assays and analysis standards, and also, the manner by which the results were expressed varied greatly, making it difficult to conduct comparative analyses of findings across research groups. Furthermore, there appears to be no agreed protocol to guide the extraction process itself, which is required to establish baseline data for bee pollen of Australian origin in order to compare their antioxidant activity with other bee pollen samples. The gaps in information form the basis for this study, which aimed to optimise the extraction conditions for bee pollen collected in western Australia to enable the maximum extraction of antioxidant constituents as measured by the TPC, DPPH and FRAP assays. The Design of Experiment approach examined three independent variables: sample pulverisation, extraction solvent, and the extraction process. The two pollen types provided sample diversity to enable the development of a generalised extraction protocol that may be adopted for all types of bee pollen collected in western Australian and beyond.

\subsection{Analysis of the Optimisation Process}

A multilevel factorial design was implemented using Design Expert 12 (StatEase Inc., Minneapolis, MN, USA), with sample pulverisation, extraction solvent, and the extraction process as independent variables. The conditions selected for each variable were based on the popularity of use, as reflected in the literature review (Table 1). The responses (dependent variables) measured were the TPC, DPPH, and FRAP antioxidant activities. As summarised in Table 3 (the full data set is available as Supplementary Material, Table S1), the extraction variables for the multilevel factorial design (categorical) were selected at two levels for pulverisation $(\mathrm{A}$, crude $=-$, pulverised $=+$ ), four levels for extraction solvent $(\mathrm{B}$, $70 \%$ ethanol: $30 \%=\mathrm{E} 70: 30$, ethanol $=\mathrm{EtOH}$, water $=\mathrm{H}_{2} \mathrm{O}$, and methanol $=\mathrm{MtOH}$ ), and four levels for the extraction process $(C$, agitation $=A$, maceration $=M$, reflux $=R$, and sonication $=\mathrm{S}$ ). The total runs consisted of 32 experimental points, and each point was triplicated. The sequence of the experiments was randomised, where the random numbers were generated by the Design Expert 12 software.

Pulverisation (Variable A) did not show any significant effect on the TPC, DPPH and FRAP data for the bee pollen ( $p$ value $>0.05)$ and was therefore removed from further analysis. Both solvent type (Variable B) and the extraction process (Variable $C$ ) were found to have significant impacts on the TPC, DPPH and FRAP antioxidant activity of bee pollen ( $p$ value $<0.05)$. A significant interaction between the solvent type and extraction process (Variables B and C) was observed for the TPC and FRAP responses ( $p$ value $<0.05$ ), whereas the interaction of these variables did not influence the DPPH antioxidant activity.

However, the larger coefficients obtained for extraction solvent relative to those for the extraction process indicate that the selection of solvent has a dominant effect on all three responses based on the tabulated regression coefficients (see Table 4), also seen in Pareto charts (Figures 1-3). 
Table 3. Multilevel factorial experimental design to optimise the extraction of antioxidant components in bee pollen. Experiments were conducted with 3 independent variables and the responses comprised of antioxidant activity measured by the TPC, DPPH and FRAP assays.

\begin{tabular}{|c|c|c|c|c|c|c|c|}
\hline \multirow[b]{2}{*}{ Run } & \multicolumn{3}{|c|}{ Independent Variables } & \multicolumn{4}{|c|}{ Dependent Variables } \\
\hline & Pulverisation & Solvent & Extraction & TPC & DPPH & FRAP & $\begin{array}{c}\text { DPPH/FRAP } \\
\text { Ratio }\end{array}$ \\
\hline 1 & - & E70:30 & A & $20.86 \pm 4.07$ & $320.11 \pm 27.00$ & $342.28 \pm 55.57$ & 1.07 \\
\hline 2 & + & E70:30 & A & $20.85 \pm 2.67$ & $331.86 \pm 43.20$ & $357.36 \pm 35.65$ & 1.08 \\
\hline 3 & - & E70:30 & M & $19.99 \pm 1.08$ & $267.92 \pm 39.77$ & $396.39 \pm 14.23$ & 1.48 \\
\hline 4 & + & E70:30 & M & $19.42 \pm 2.13$ & $291.42 \pm 56.06$ & $349.19 \pm 90.21$ & 1.20 \\
\hline 5 & - & E70:30 & $\mathrm{R}$ & $21.37 \pm 1.70$ & $309.28 \pm 32.62$ & $326.54 \pm 34.19$ & 1.17 \\
\hline 6 & + & E70:30 & $\mathrm{R}$ & $20.46 \pm 1.33$ & $300.81 \pm 48.42$ & $328.85 \pm 40.44$ & 1.16 \\
\hline 7 & - & E70:30 & $S$ & $18.80 \pm 2.20$ & $266.37 \pm 56.46$ & $326.61 \pm 62.16$ & 1.23 \\
\hline 8 & + & E70:30 & $S$ & $19.68 \pm 2.87$ & $296.61 \pm 55.53$ & $338.49 \pm 59.04$ & 1.14 \\
\hline 9 & - & $\mathrm{EtOH}$ & A & $16.61 \pm 2.15$ & $298.92 \pm 14.55$ & $286.19 \pm 29.22$ & 0.88 \\
\hline 10 & + & $\mathrm{EtOH}$ & A & $16.92 \pm 3.23$ & $297.37 \pm 15.99$ & $289.85 \pm 45.37$ & 0.97 \\
\hline 11 & - & $\mathrm{EtOH}$ & M & $17.03 \pm 2.24$ & $244.52 \pm 55.49$ & $302.95 \pm 33.92$ & 1.24 \\
\hline 12 & + & $\mathrm{EtOH}$ & M & $16.84 \pm 1.72$ & $236.25 \pm 52.65$ & $297.27 \pm 33.84$ & 1.28 \\
\hline 13 & - & $\mathrm{EtOH}$ & $\mathrm{R}$ & $19.35 \pm 1.08$ & $285.28 \pm 32.63$ & $323.98 \pm 29.19$ & 1.36 \\
\hline 14 & + & $\mathrm{EtOH}$ & $\mathrm{R}$ & $18.84 \pm 2.00$ & $262.40 \pm 37.24$ & $310.51 \pm 32.89$ & 1.25 \\
\hline 15 & - & $\mathrm{EtOH}$ & $S$ & $15.67 \pm 2.24$ & $231.12 \pm 52.88$ & $269.77 \pm 24.22$ & 1.17 \\
\hline 16 & + & $\mathrm{EtOH}$ & $S$ & $16.57 \pm 2.16$ & $251.47 \pm 37.37$ & $286.61 \pm 31.22$ & 1.14 \\
\hline 17 & - & $\mathrm{H}_{2} \mathrm{O}$ & A & $3.50 \pm 0.52$ & $34.67 \pm 10.93$ & $45.06 \pm 12.36$ & 1.30 \\
\hline 18 & + & $\mathrm{H}_{2} \mathrm{O}$ & $\mathrm{A}$ & $3.68 \pm 0.18$ & $34.22 \pm 6.14$ & $44.05 \pm 12.66$ & 1.29 \\
\hline 19 & - & $\mathrm{H}_{2} \mathrm{O}$ & M & $3.58 \pm 0.55$ & $20.91 \pm 3.80$ & $44.42 \pm 6.33$ & 2.13 \\
\hline 20 & + & $\mathrm{H}_{2} \mathrm{O}$ & M & $3.34 \pm 0.30$ & $26.04 \pm 10.26$ & $43.01 \pm 8.44$ & 1.65 \\
\hline 21 & - & $\mathrm{H}_{2} \mathrm{O}$ & $\mathrm{R}$ & $5.07 \pm 1.45$ & $49.21 \pm 13.94$ & $83.66 \pm 23.00$ & 2.83 \\
\hline 22 & + & $\mathrm{H}_{2} \mathrm{O}$ & $\mathrm{R}$ & $4.98 \pm 1.69$ & $49.9 \pm 20.24$ & $80.89 \pm 27.60$ & 2.14 \\
\hline 23 & - & $\mathrm{H}_{2} \mathrm{O}$ & $S$ & $4.26 \pm 0.29$ & $31.72 \pm 10.94$ & $55.64 \pm 9.42$ & 1.75 \\
\hline 24 & + & $\mathrm{H}_{2} \mathrm{O}$ & $S$ & $4.35 \pm 0.49$ & $34.55 \pm 4.53$ & $56.99 \pm 6.81$ & 1.65 \\
\hline 25 & - & $\mathrm{MtOH}$ & A & $19.55 \pm 2.22$ & $311.92 \pm 33.70$ & $196.83 \pm 43.71$ & 0.63 \\
\hline 26 & + & $\mathrm{MtOH}$ & $\mathrm{A}$ & $19.25 \pm 3.26$ & $298.15 \pm 47.53$ & $237.14 \pm 18.04$ & 0.80 \\
\hline 27 & - & $\mathrm{MtOH}$ & M & $19.17 \pm 3.29$ & $267.20 \pm 62.25$ & $221.76 \pm 66.73$ & 0.83 \\
\hline 28 & + & $\mathrm{MtOH}$ & M & $18.58 \pm 2.90$ & $236.85 \pm 46.00$ & $268.84 \pm 38.98$ & 1.14 \\
\hline 29 & - & $\mathrm{MtOH}$ & $\mathrm{R}$ & $21.15 \pm 3.20$ & $253.10 \pm 25.66$ & $254.02 \pm 30.52$ & 1.06 \\
\hline 30 & + & $\mathrm{MtOH}$ & $\mathrm{R}$ & $20.00 \pm 3.41$ & $261.09 \pm 41.84$ & $270.53 \pm 14.49$ & 1.11 \\
\hline 31 & - & $\mathrm{MtOH}$ & $S$ & $17.85 \pm 2.21$ & $254.80 \pm 65.14$ & $216.45 \pm 26.87$ & 0.85 \\
\hline 32 & + & $\mathrm{MtOH}$ & S & $17.95 \pm 2.21$ & $261.78 \pm 70.17$ & $241.74 \pm 19.54$ & 0.92 \\
\hline
\end{tabular}

The relationships between the independent variables and TPC, DPPH and FRAP assays are further illustrated in three-dimensional graphs (Figures 4-6). Figure 4 shows the results for the TPC assay of the bee pollen samples. The highest responses were observed when a solvent of 70\% ethanol (E70:30) was coupled with reflux (R) or agitation (A) as the extraction process $(p$ value $<0.05)$. These conditions may therefore represent optimal parameters for the extraction of the bee pollen samples for the TPC assay. For the DPPH antioxidant activity (Figure 5), the extraction solvent of 70\% ethanol (E70:30) coupled with agitation (A) were the best extracting conditions for the bee pollen samples ( $p$ value $<0.001$ ). Figure 6 shows that the extraction solvent of 70\% ethanol (E70:30) coupled with maceration (M) produced the highest FRAP activity ( $p$ value $<0.05$ ), and may therefore be considered as the combination of solvent type and the extraction process of choice for the FRAP assay of the bee pollen samples. 
Table 4. Summary of regression coefficients. $\mathrm{A}[n]=$ pulverisation; $\mathrm{B}[n]=$ solvent type; $\mathrm{C}[n]=$ extraction process; $\mathrm{AB}[n]=$ interaction of pulverisation and solvent, $\mathrm{B}[n] \mathrm{C}[n]=$ interaction of solvent type and extraction process. ${ }^{*}=$ significant $p$-value $<0.05$.

\begin{tabular}{|c|c|c|c|}
\hline \multicolumn{4}{|c|}{ Coefficient Estimate } \\
\hline Term & TPC & DPPH & FRAP \\
\hline Intercept & 3.76 & 13.71 & 14.64 \\
\hline A & - & - & 0.1503 \\
\hline $\mathrm{B}[1]$ & 0.7323 * & $3.36^{*}$ & $3.93 *$ \\
\hline $\mathrm{B}[2]$ & $0.3897 *$ & $2.26 *$ & $2.47 *$ \\
\hline $\mathrm{B}[3]$ & $-1.74 *$ & $-8.15^{*}$ & $-7.18 *$ \\
\hline$C[1]$ & $-0.0195 *$ & $0.9483 *$ & -0.4800 * \\
\hline$C[2]$ & $-0.0691 *$ & $-0.4900 *$ & 0.0891 * \\
\hline$C[3]$ & $0.1706^{*}$ & -0.2780 * & $0.6496^{*}$ \\
\hline $\mathrm{AB}[1]$ & - & - & -0.2061 \\
\hline $\mathrm{AB}[2]$ & - & - & -0.0267 \\
\hline $\mathrm{AB}[3]$ & - & - & -0.1826 \\
\hline $\mathrm{B}[1] \mathrm{C}[1]$ & $0.0937 *$ & - & $0.6036^{*}$ \\
\hline $\mathrm{B}[2] \mathrm{C}[1]$ & $-0.0348^{*}$ & - & -0.0579 * \\
\hline $\mathrm{B}[3] \mathrm{C}[1]$ & -0.1043 * & - & $-0.3087^{*}$ \\
\hline $\mathrm{B}[1] \mathrm{C}[2]$ & $0.0177 *$ & - & $0.6213^{*}$ \\
\hline $\mathrm{B}[2] \mathrm{C}[2]$ & $0.0365 *$ & - & 0.1917 * \\
\hline $\mathrm{B}[3] \mathrm{C}[2]$ & $-0.0886^{*}$ & - & $-0.9382 *$ \\
\hline $\mathrm{B}[1] \mathrm{C}[3]$ & $-0.0886^{*}$ & - & $-1.14 *$ \\
\hline $\mathrm{B}[2] \mathrm{C}[3]$ & 0.0498 * & - & 0.0415 * \\
\hline $\mathrm{B}[3] \mathrm{C}[3]$ & 0.0529 * & - & 0.9468 * \\
\hline
\end{tabular}

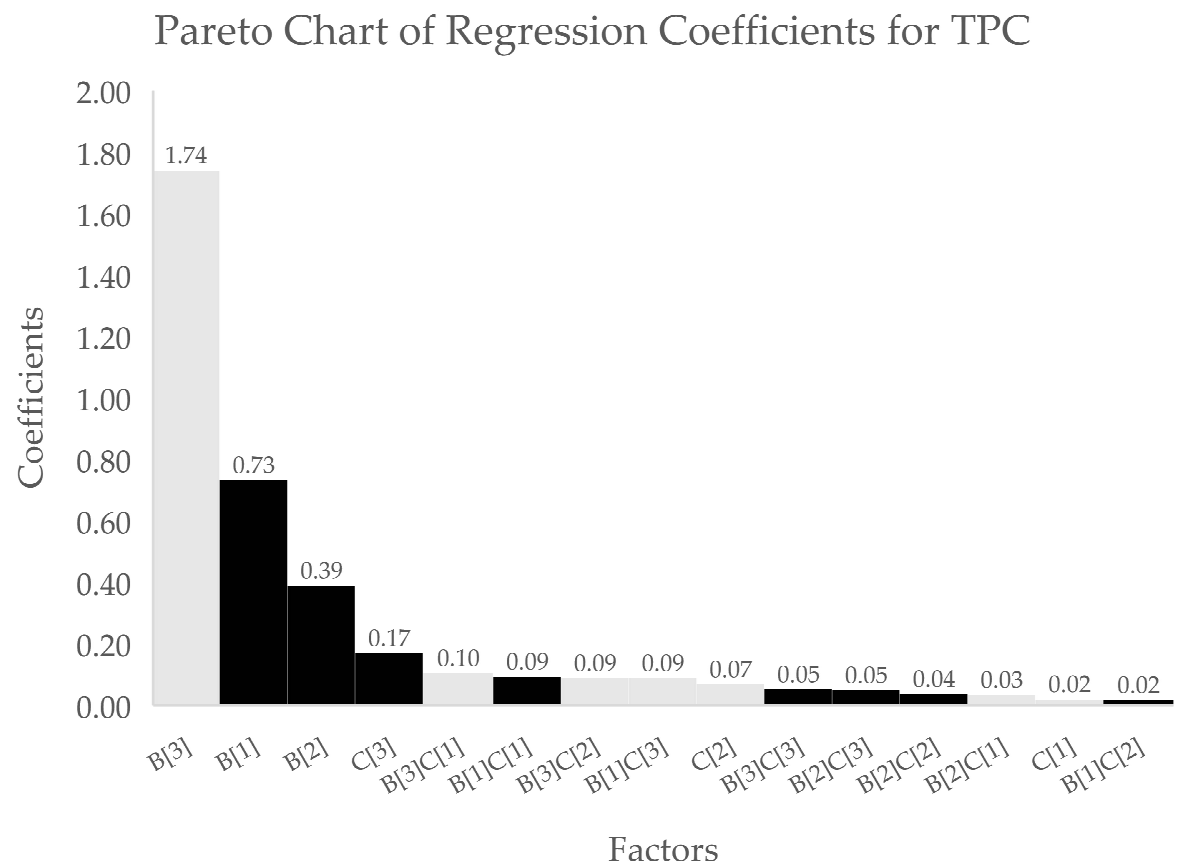

Figure 1. Pareto chart of regression coefficients for TPC assay data. X-axis indicates the different factors $(\mathrm{B}[n]=$ solvent type, $\mathrm{C}[n]=$ extraction process, and $\mathrm{B}[n] \mathrm{C}[n]=$ interaction of solvent type and extraction process) while the values in the left $y$-axis indicate the coefficient values for the corresponding factors. Black bars indicate positive effect, while white bars indicate negative effect on TPC. 


\section{Pareto Chart of Regression Coefficients for}

$\mathrm{DPPH}$

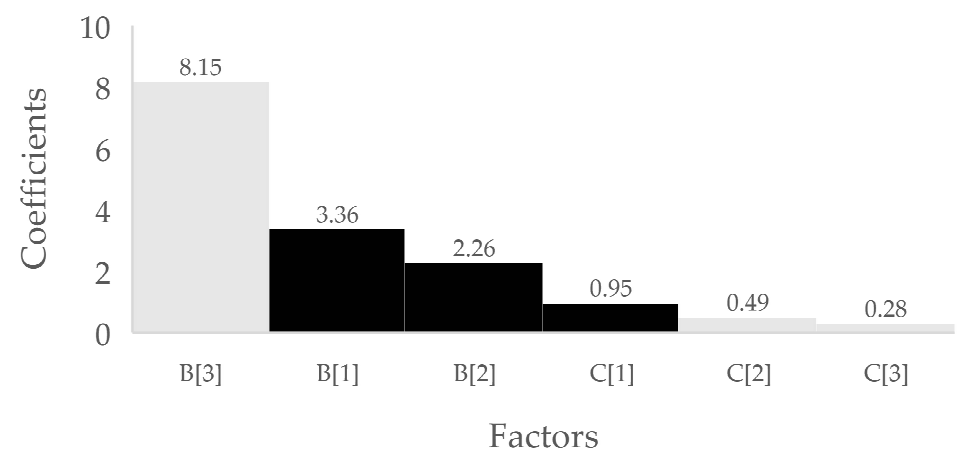

Figure 2. Pareto chart of regression coefficients for DPPH antioxidant activity data. X-axis indicates the different factors $(\mathrm{B}[n]=$ solvent type and $\mathrm{C}[n]=$ extraction process, $)$ while the values in the left $\mathrm{y}$-axis indicate the coefficient values for the corresponding factors. Black bars indicate positive effect, while white bars indicate negative effect on DPPH antioxidant activity.

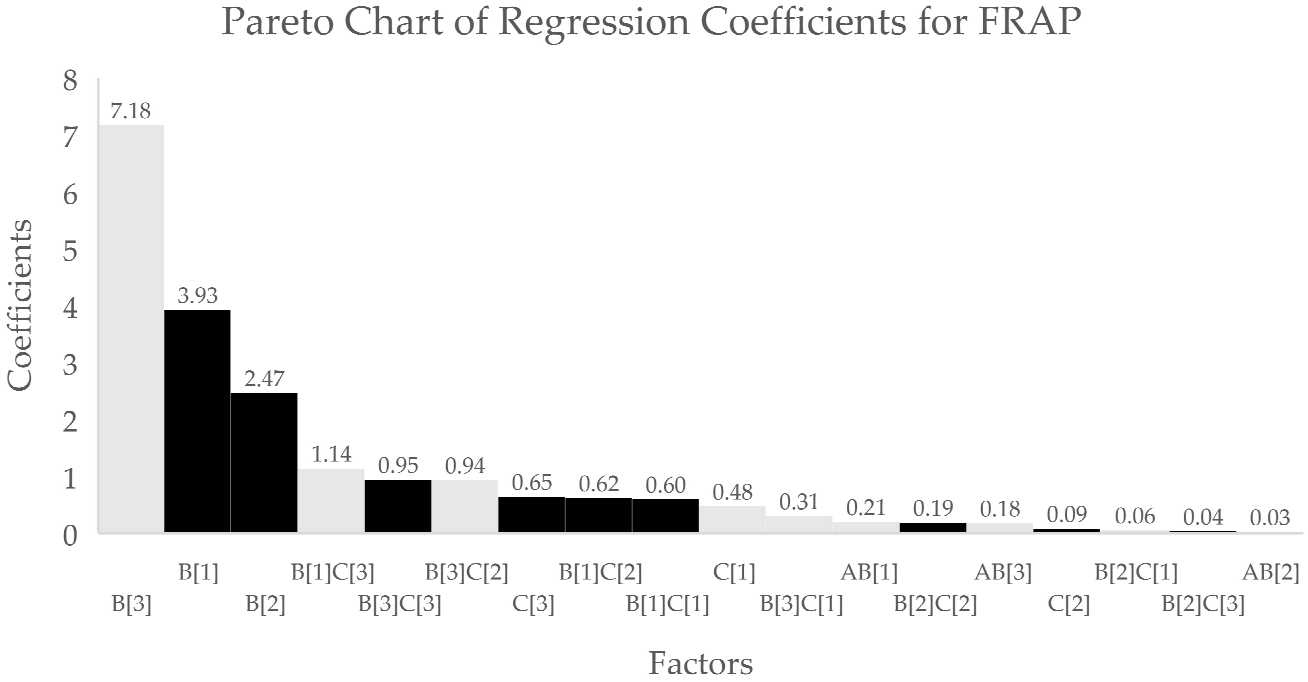

Figure 3. Pareto chart of regression coefficients for FRAP antioxidant activity data. $\mathrm{X}$-axis indicates the different factors $(\mathrm{A}[n]=$ pulverisation, $\mathrm{B}[n]=$ solvent type, $\mathrm{C}[n]=$ extraction process, $\mathrm{AB}[n]=$ interaction of pulverisation and solvent, $\mathrm{B}[n] \mathrm{C}[n]=$ interaction of solvent type and extraction process) while the values in the left $\mathrm{x}$-axis indicate the coefficient values for the corresponding factors. Black bars indicate positive effect, while white bars indicate negative effect on DPPH antioxidant activity. 


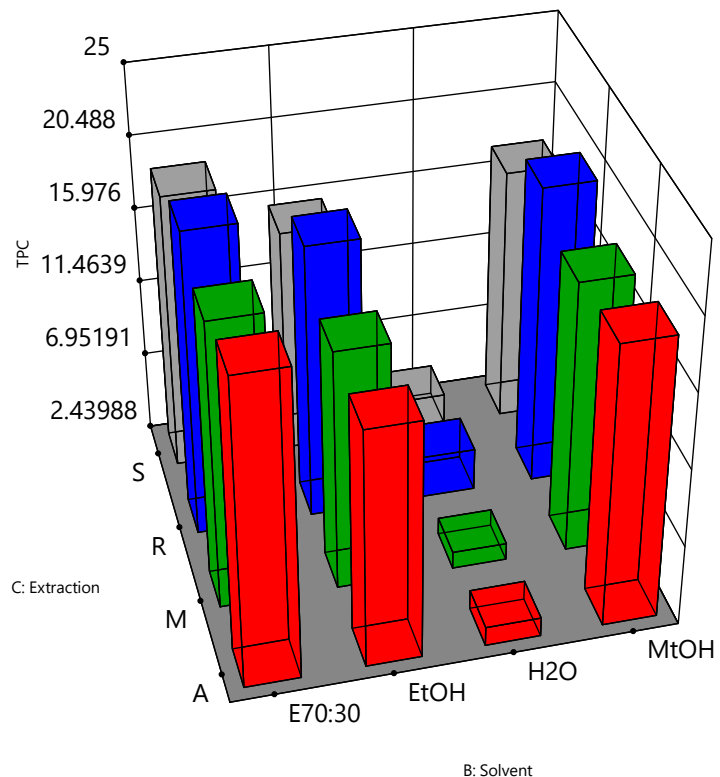

Figure 4. Interactive effects of extraction solvent and extraction method on the TPC assay for bee pollen samples. TPC values were expressed as mg gallic acid equivalent per gram pollen, $\mathrm{B}$ : extraction solvent $\left(70 \%\right.$ ethanol:30\% $=\mathrm{E} 70: 30$, ethanol $=\mathrm{EtOH}$, water $=\mathrm{H}_{2} \mathrm{O}$, and methanol $\left.=\mathrm{MtOH}\right)$ and C: extraction process (agitation $=\mathrm{A}$, maceration $=\mathrm{M}$, reflux $=\mathrm{R}$, and sonication $=\mathrm{S}$ ).

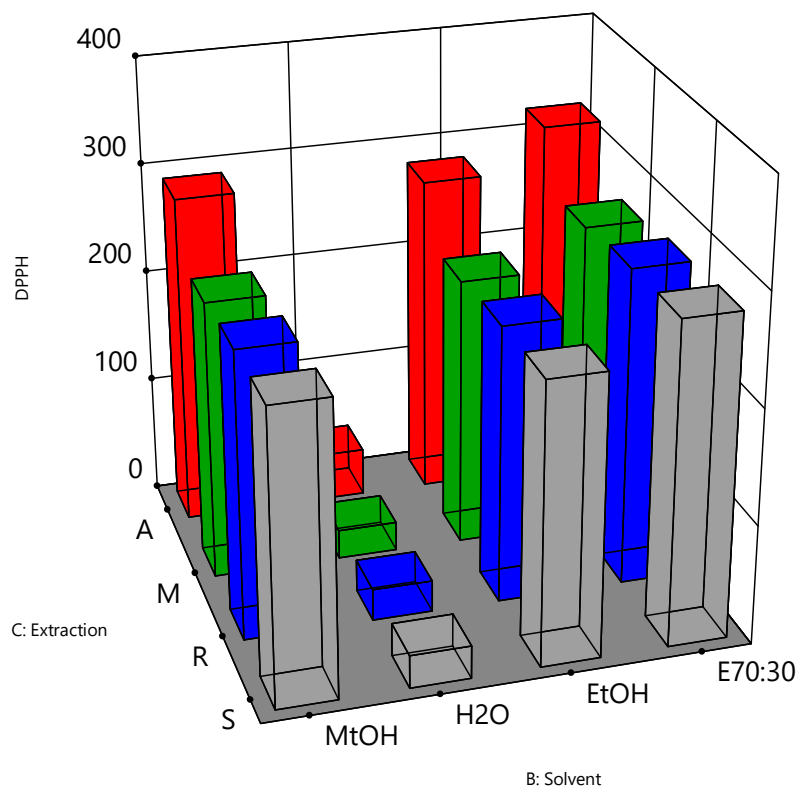

Figure 5. Effects of extraction solvent and extraction method on the DPPH antioxidant activity for bee pollen samples. DPPH values were expressed as $\mu$ mol Trolox equivalent per gram pollen, $\mathrm{B}$ : extraction solvent $\left(70 \%\right.$ ethanol:30\% $=\mathrm{E} 70: 30$, ethanol $=\mathrm{EtOH}$, water $=\mathrm{H}_{2} \mathrm{O}$, and methanol $\left.=\mathrm{MtOH}\right)$ and $\mathrm{C}$ : extraction process (agitation $=\mathrm{A}$, maceration $=\mathrm{M}$, reflux $=\mathrm{R}$, and sonication $=\mathrm{S}$ ). 


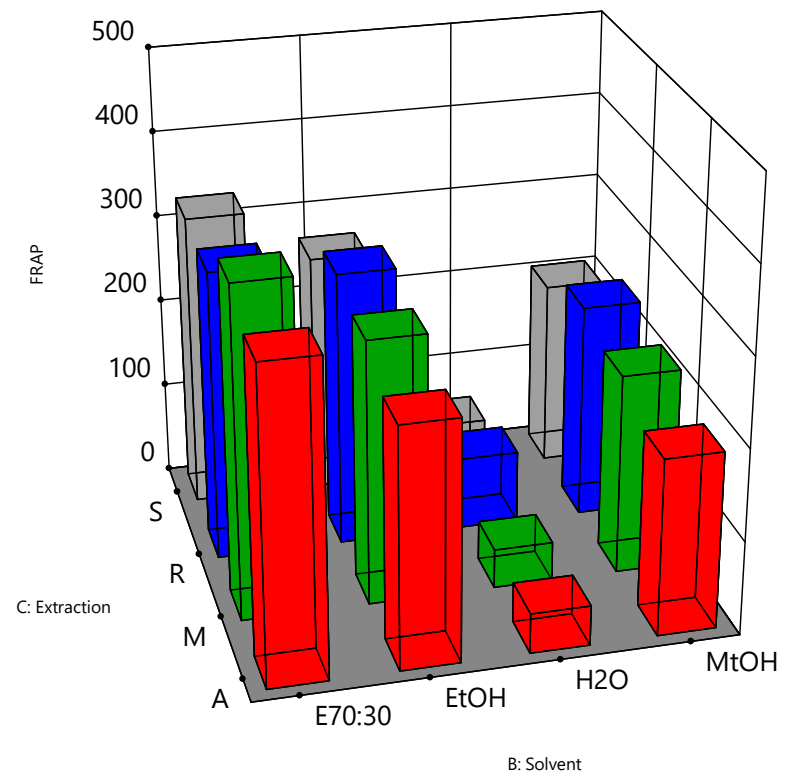

Figure 6. Interaction effects of extraction solvent and extraction method on the FRAP antioxidant activity for bee pollen samples. FRAP values were expressed as $\mu \mathrm{mol} \mathrm{Fe} \mathrm{F}^{+2}$ equivalent per gram pollen, B: extraction solvent $\left(70 \%\right.$ ethanol:30\% $=\mathrm{E} 70: 30$, ethanol $=\mathrm{EtOH}$, water $=\mathrm{H}_{2} \mathrm{O}$, and methanol $\left.=\mathrm{MtOH}\right)$ and $\mathrm{C}$ : extraction process (agitation $=\mathrm{A}$, maceration $=\mathrm{M}$, reflux $=\mathrm{R}$, and sonication $=\mathrm{S}$ ).

\subsection{Correlation of TPC, DPPH and FRAP Antioxidant Activity}

Bee pollen has been reported to contain many types of polyphenols [99] which are strongly correlated to the antioxidant activity of bee pollen [9]. In this study, a strong positive correlation was observed between the TPC and DPPH data, TPC and FRAP data as well as the DPPH and FRAP data, with correlation values of $\rho=0.6925(p<0.001)$, $\rho=0.7295(p<0.001)$ and $\rho=0.6520(p<0.001)$, respectively. Thus, the presence of polyphenols, captured in the pollen's TPC, appears to positively influence its antioxidant capacity expressed in the DPPH and FRAP assays. However, it needs to be acknowledged that there are other pollen constituents, such as carotenoids, that could also influence the antioxidant capacity $[82,106]$.

\subsection{Choosing Optimum Conditions}

The optimisation of the extraction process to maximise the three dependent variables was determined by employing a new variable desirability, which represents all responses simultaneously. Desirability is an objective function that is determined by ranked responses and its value ranges from zero to one, with one being most desirable. When there are several responses, the individual goals are combined to generate one desirability function, which was automated by Design Expert software 12 (StatEase, Inc. Minneapolis, MN, USA). The numerical optimisation based on the goal of the study finds a point that maximises the desirability function. The criteria adopted to determine the desirability function for this study are to maximise all responses. Figures 7-9 provide predicted TPC, DPPH and FRAP values obtained for the three optimum conditions identified for the extraction of bee pollen samples. 

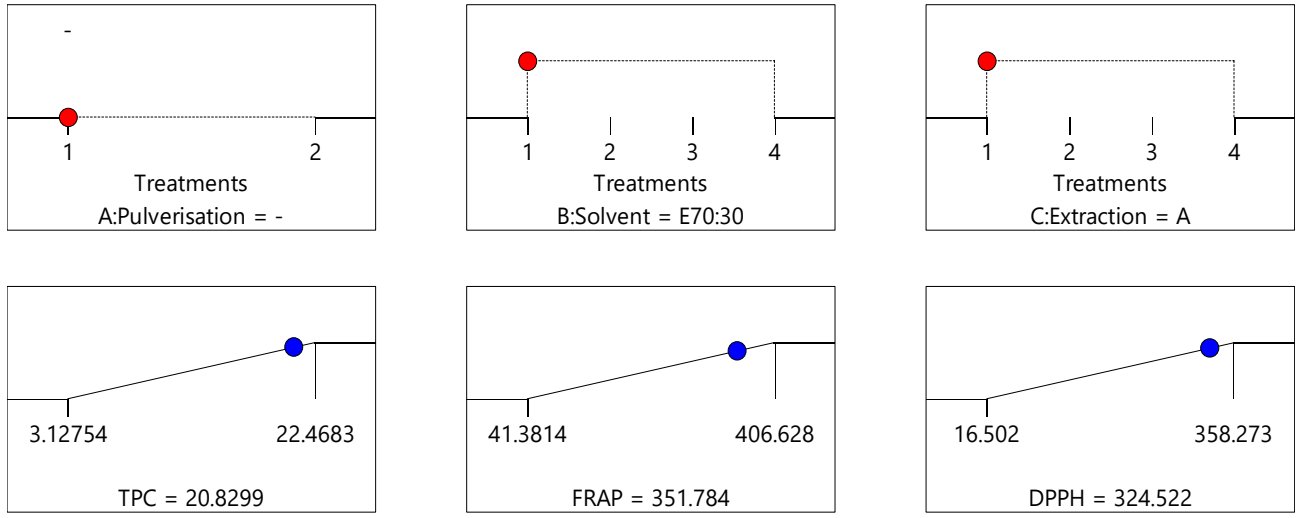

Figure 7. Proposed optimised extraction condition 1: crude/non-pulverised sample extracted using $70 \%$ ethanol:30\% water (E70:30) and agitation (A), corresponding to the optimal conditions see in Figure 4 for TPC data, Figure 5 for DPPH data, and Figure 6 for FRAP data (desirability $=0.925$ ).
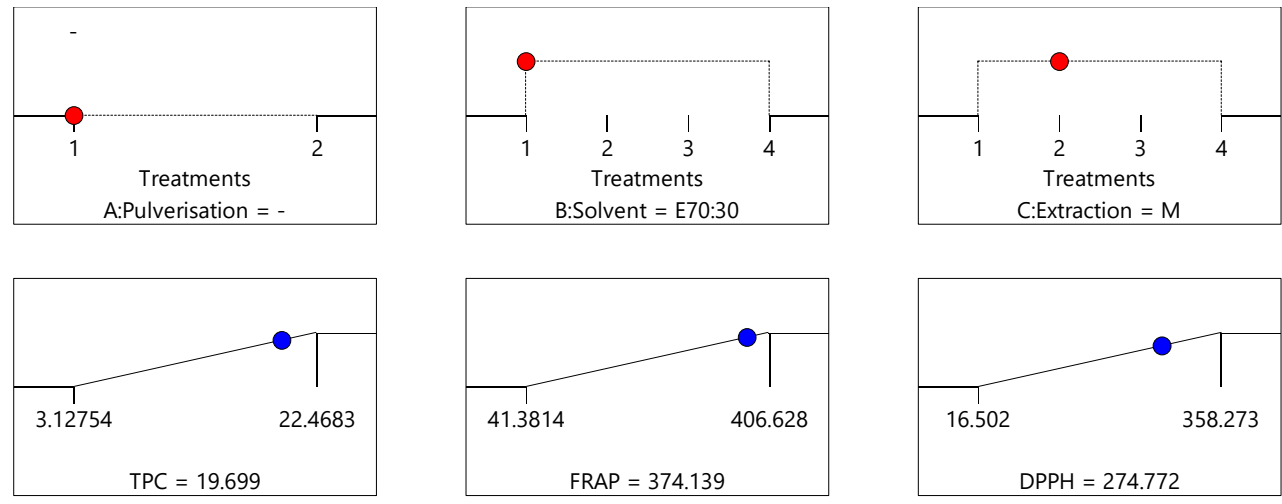

Figure 8. Proposed optimised extraction condition 2: crude/non-pulverised sample extracted using 70\% ethanol:30\% water (E70:30) and maceration (M), corresponding to the optimal conditions see in Figure 4 for TPC data, Figure 5 for DPPH data, and Figure 6 for FRAP data (desirability $=0.893$ ).
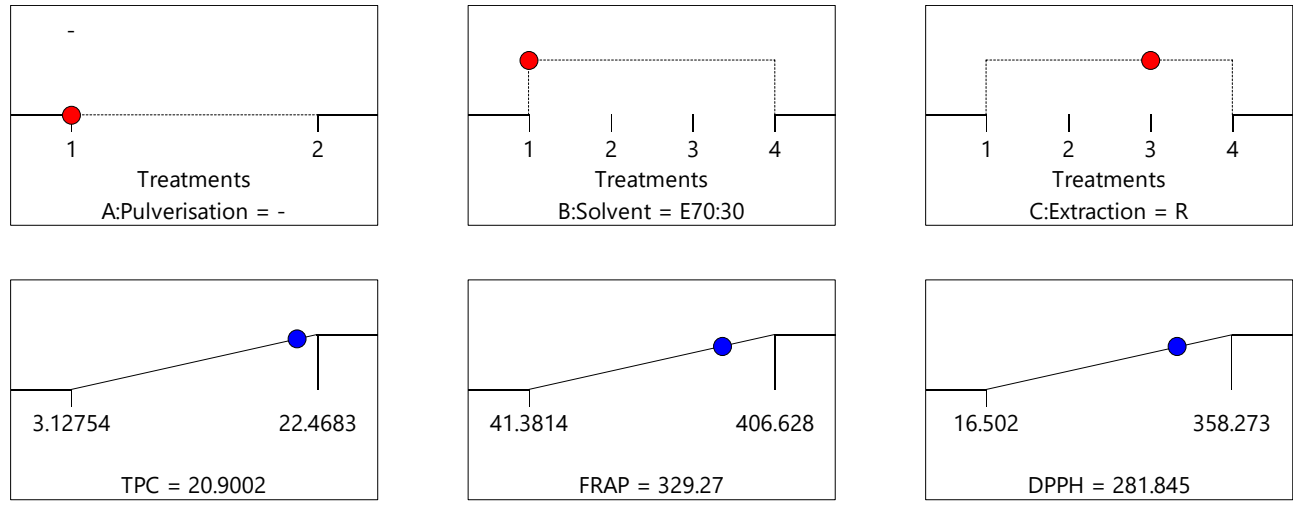

Figure 9. Proposed optimised extraction condition 3: crude/non-pulverised sample extracted using 70\% ethanol:30\% water (E70:30) and reflux (R), corresponding to the optimal conditions see in Figure 4 for TPC data, Figure 5 for DPPH data, and Figure 6 for FRAP data (desirability $=0.883$ ).

Based on the model, the crude/non-pulverised pollen sample, extracted with $70 \%$ ethanol:30\% water (E70:30) by agitation (A) as the extraction process produced the highest desirability (0.92) (Figure 7), followed by the crude/non-pulverised pollen sample, extracted with 70\% ethanol:30\% water (E70:30) by maceration $(\mathrm{M})$ (desirability $=0.893)$ (Figure 8), and finally, the non-pulverised pollen sample, extracted with $70 \%$ ethanol:30\% 
water $(E 70: 30)$ by reflux $(\mathrm{R})($ desirability $=0.883)$ (Figure 9). These three conditions can therefore be considered to represent the optimal combination of sample pre-processing treatment, solvent type and extraction process to yield the maximum extraction of constituents from the bee pollen samples for the TPC, DPPH and FRAP assays. The bee pollen extracts prepared using the crude/non-pulverised pollen sample, extracted with $70 \%$ ethanol:30\% water (E70:30) by agitation $(\mathrm{A})$ as the extraction process were found to have an average total phenolic content of $20.86 \mathrm{mg} \mathrm{GAE} / \mathrm{g}$, DPPH antioxidant activity of $320.11 \mu \mathrm{mol} \mathrm{TE} / \mathrm{g}$ and $342.28 \mu \mathrm{mol} \mathrm{Fe} \mathrm{e}^{+2} \mathrm{E} / \mathrm{g}$ FRAP activities, respectively. These values are very close to the predicted values of $20.83 \mathrm{mg}$ GAE/g, $324.52 \mu \mathrm{mol} \mathrm{TE} / \mathrm{g}$ and $351.78 \mu \mathrm{mol}$ $\mathrm{Fe}^{+2} \mathrm{E} / \mathrm{g}$, respectively, demonstrating the good fit of the chosen model.

\section{Discussion}

Commonly, the initial stage in studying the chemical composition and/or bioactivity of natural products, including bee pollen, includes a pre-extraction step, in which the material undergoes drying in order to preserve the biomolecules present in the sample [21]. This is often followed by grinding the dried material using a mortar and pestle, electric blender or various mills to decrease the particle size to enhance surface contact with the extraction solvent [21]. Particles that are too fine will, however, adsorb onto filters and impede filtration [118]. In this study, the effect of the pulverisation of bee pollen samples on its total phenolic content and associated antioxidant activity as captured by DPPH and FRAP assays was analysed. On the basis of these findings, the pulverisation process can be omitted from the extraction protocol.

The selection of solvent is crucial for solvent extraction, with selectivity for the target compounds, the target compound's solubility as well as cost and safety to be considered. Based on the law of similarity and intermiscibility, solvents with a polarity value near the polarity of the solute are likely to perform better [118]. Water, along with a range of alcoholic and organic solvents such as methanol, ethanol, acetonitrile, acetone, hexane and diethyl ether are commonly utilised in the extraction of bioactive compounds [20]. The current study aimed to analyse the impact of different solvents, including water, methanol $(\mathrm{M})$, ethanol (E) and the combination of ethanol and water at a ratio of 70:30 (v/v) (E70:30) on the total phenolic content as well as DPPH and FRAP antioxidant activity of pollen samples collected from western Australia. The findings of the study demonstrate that the extraction solvent had the strongest influence on the responses of the dependent variables $(p<0.05)$. Among the solvents tested, extracts prepared with $70 \%$ ethanol:30\% water $(v / v)$ demonstrated the highest activity across all performed assays.

Based on the interactions observed in this study, it appears that TPC values are dependent on solvent type and the extraction process, and it can be concluded that TPC can be maximised when the pollen extraction is carried out either using 70\% ethanol:30\% water coupled with agitation or reflux. DPPH antioxidant activity is maximised following agitation as an extraction process in any of the investigated solvents, whereas FRAP antioxidant activity is highest when pollen is extracted with maceration coupled with $70 \%$ ethanol:30\% water. Bee pollen contains $13-55 \%$ of carbohydrates [6-8] and it can be assumed that some can be carried over into the extract by polar solvents. Consequently, the prolonged heating of bee pollen at a high temperature might lead to the formation of Maillard products from these carbohydrates during processing [3]. Therefore, an extraction method that does not expose the pollen sample to prolonged high temperatures can be considered favourable. Maceration is an easy process in extracting antioxidant principles; however, it takes $72 \mathrm{~h}$ to complete, as compared to agitation, which only requires $6 \mathrm{~h}$. Reflux is a very promising method of extraction, as it only requires $2 \mathrm{~h}$ to perform; however, depending on the chosen solvent, it might require high temperature in order to operate. Thus, in this light, agitation can be recommended as the optimal extraction process to maximise antioxidant principles obtained from bee pollen samples.

The term 'phenolic' or 'polyphenol' is chemically defined as a substance that possesses an aromatic ring bearing one or more hydroxyl substituents, including functional 
derivatives such as esters, methyl esters and glycosides. These bioactive compounds are extensively found across the plant kingdom and are closely linked with the sensory and nutritional quality of fresh and processed plant foods, including bee products such as honey and bee pollen [9]. Keskin and Özkök reported various multifloral bee pollen samples from the Czech Republic to have a total phenolic content ranging from $15.2 \mathrm{mg}$ to $22.73 \mathrm{mg}$ GAE/g pollen [38], whereas Mayda, Özkök et al. reported TPC values of $26.69 \pm 0.595$ and $43.42 \pm 0.7794 \mathrm{mg} \mathrm{GAE} / \mathrm{g}$ pollen [58]. TPC for multifloral bee pollen from Morocco was reported as $45.96 \pm 0.51 \mathrm{mg} \mathrm{GAE} / \mathrm{g}$ pollen [63] and samples obtained from Hungary had TPC values ranging from $9.15 \pm 0.12$ to $13.63 \pm 0.11 \mathrm{mg} \mathrm{GAE} / \mathrm{g}$ pollen [72]. TPC values (mg GAE/g pollen) for the two western Australian monofloral pollen samples investigated as part of this study following the optimised extraction protocol by using non-pulverised samples extracted with $70 \%$ ethanol:30\% via agitation was $20.86 \mathrm{mg}$ GAE/g. With this, the TPC value of the western Australian pollens are broadly within typical ranges found for a range of bee pollen samples from a wide geographical spread. It needs to be highlighted, though, that comparisons between data generated in different studies need to be treated with caution, as the chosen extraction condition (solvent and extraction method) will impact on the obtained TPC data. Furthermore, the method used in the analysis of TPC in this study utilised a Folin-Ciocalteu method in slightly basic medium ( $0.75 \%$ sodium carbonate) as compared to most researchers that used $7.5 \%$ sodium carbonate. This amendment to the common assay protocol was found to be necessary, since reducing sugars present in alcoholic and aqueous pollen extracts can also be reduced by the reagent, and thus, lead to an overestimation of TPC. [119]

The optimised extraction protocol was also used to assess the antioxidant activity of the two western Australian pollen samples investigated in this study. Despite relatively high correlations between FRAP, DPPH and TPC values found in this study, it can be argued that in vitro antioxidant capacity should not be determined by means of a single antioxidant test model because of the diverse types of antioxidant that might be present in the sample as well as the intricacy of the natural product matrix and the variety of free radical reaction mechanisms involved in oxidation. Complementary antioxidant assays might, therefore, produce richer data [78]. Thus, in this study, the antioxidant potential of bee pollen extracts was determined by means of two different radical scavenging assays, namely DPPH and FRAP.

Using the DPPH assay, Rocchetti and Castiglioni reported Magnolia and Lamium bee pollen from Italy to have antioxidant activities of 11.9 and $134.7 \mu \mathrm{mol} \mathrm{TE} / \mathrm{g}$ pollen, respectively [78]. Mărghitaş et al. reported DPPH antioxidant activities ranging from 135 to $2814 \mu \mathrm{mol} \mathrm{TE} / \mathrm{g}$ for various monofloral pollens from Romania [28] and Saral et al. found DPPH scavenging activities between 13.87 and $15.04 \mathrm{mg}$ TE/g for multifloral pollen from Turkey [74]. DPPH data generated in this study for the western Australian pollen samples were $320.11 \mu \mathrm{mol}$ (equivalent to $80.12 \mathrm{mg}$ ) TE/g following the optimised extraction protocol using non-pulverised pollen extracted with E70:30 by agitation. These findings are within the range of values reported by others.

Using the FRAP assay, Zuluaga-Domínguez et al. reported $87.2 \pm 15.6 \mu \mathrm{mol}$ Trolox/g for multifloral pollen from Colombia [37], whereas Saral et al. found a FRAP activity ranging from 8.69 to $84.89 \mu \mathrm{mol} \mathrm{Fe}{ }^{2+} \mathrm{E} / \mathrm{g}$ for multifloral bee pollen from Turkey [74]. In this study, following the optimised extraction protocol by using non-pulverised pollen extracted with E70:30 by agitation, FRAP antioxidant activity was found to be $342.28 \mu \mathrm{mol}$ $\mathrm{Fe}^{+2} \mathrm{E} / \mathrm{g}$, which is higher than the values reported by Saral et al. However, the comparison of FRAP values appears even more difficult, not only because the results are dependent on the chosen extraction conditions but also because the studies use different reference standards (Trolox or $\mathrm{Fe}^{2+}$ ) to express their results.

\section{Conclusions}

Based on a thorough review of the extant literature, a number of common bee pollen processing steps, solvents and extraction methods were identified, which can all impact on 
extraction efficiency and thus result in different TPC, DPPH and FRAP values. The study reports on an in-depth investigation into the optimisation of the most popular extraction conditions for maximum TPC, DPPH and FRAP antioxidant activity using two bee pollen samples from western Australia. The effects of pulverisation, the chosen solvent (70\% aqueous ethanol, ethanol, methanol and water) as well as the adopted extraction process (agitation, maceration, reflux and sonication) were determined in order to optimise the extraction parameters. The study's findings demonstrate that non-pulverised pollen extracted with $70 \%$ aqueous ethanol coupled with agitation as the extraction method constitutes the best conditions in order to maximise the extraction of phenolics and antioxidant principles in these bee pollen samples.

Supplementary Materials: The following are available online at https:/ /www.mdpi.com/article/ 10.3390/antiox10071113/s1. Table S1: Data of pollen multilevel factor pollen analysis.

Author Contributions: Conceptualisation, I.L.L. and C.L.; methodology, I.L.L., O.Y. and C.L.; formal analysis, I.L.L. and O.Y.; writing — original draft preparation, I.L.L.; writing—review and editing, C.L., O.Y. and L.Y.L.; supervision, C.L., L.Y.L. and K.H.; project administration, C.L.; funding acquisition, C.L. All authors have read and agreed to the published version of the manuscript.

Funding: This research was funded by the Cooperative Research Centre for Honey Bee Products (CRC HBP).

Data Availability Statement: The data presented in this study are available as supplementary material.

Conflicts of Interest: The authors declare no conflict of interest.

\section{References}

1. LeBlanc, B.W.; Davis, O.K.; Boue, S.; DeLucca, A.; Deeby, T. Antioxidant activity of Sonoran Desert bee pollen. Food Chem. 2009, 115, 1299-1305. [CrossRef]

2. Estevinho, L.M.; Dias, T.; Anjos, O. Influence of the storage conditions (frozen vs dried) in health-related lipid indexes and antioxidants of bee pollen. Eur. J. Lipid Sci. Technol. 2018, 121, 1-9. [CrossRef]

3. Thakur, M.; Nanda, V. Composition and functionality of bee pollen: A review. Trends Food Sci. Technol. 2020, 98, 82-106. [CrossRef]

4. Bakour, M.; Fernandes, Â.; Barros, L.; Sokovic, M.; Ferreira, I.C.; Lyoussi, B. Bee bread as a functional product: Chemical composition and bioactive properties. LWT 2019, 109, 276-282. [CrossRef]

5. Nguyen, H.T.L.; Panyoyai, N.; Kasapis, S.; Pang, E.; Mantri, N. Honey and Its Role in Relieving Multiple Facets of Atherosclerosis. Nutrients 2019, 11, 167. [CrossRef] [PubMed]

6. Féas, X.; Vázquez-Tato, M.P.; Estevinho, L.; Seijas, J.A.; Iglesias, A. Organic Bee Pollen: Botanical Origin, Nutritional Value, Bioactive Compounds, Antioxidant Activity and Microbiological Quality. Molecules 2012, 17, 8359-8377. [CrossRef]

7. Kalaycıŏlu, Z.; Kaygusuz, H.; Döker, S.; Kolaylı, S.; Erim, F. Characterization of Turkish honeybee pollens by principal component analysis based on their individual organic acids, sugars, minerals, and antioxidant activities. LWT 2017, 84, 402-408. [CrossRef]

8. Wu, W.; Wang, K.; Qiao, J.; Dong, J.; Li, Z.; Zhang, H. Improving nutrient release of wall-disrupted bee pollen with a combination of ultrasonication and high shear technique. J. Sci. Food Agric. 2019, 99, 564-575. [CrossRef]

9. Hossen, M.S.; Ali, M.Y.; Jahurul, M.H.A.; Abdel-Daim, M.M.; Gan, S.H.; Khalil, M.I. Beneficial roles of honey polyphenols against some human degenerative diseases: A review. Pharmacol. Rep. 2017, 69, 1194-1205. [CrossRef]

10. Borycka, K.; Grabek-Lejko, D.; Kasprzyk, I. Antioxidant and antibacterial properties of commercial bee pollen products. J. Apic. Res. 2015, 54, 491-502. [CrossRef]

11. Ozkok, A. Determination of antioxidant capacities, chemical composition and melissopalynological characterization of Verbascum spp. and Euphorbia spp. honeys. Fresenius Environ. Bull. 2019, 28, $2644-2649$.

12. Čeksterytè, V.; Kurtinaitienè, B.; Venskutonis, P.; Pukalskas, A.; Kazernavičiūtè, R.; Balžekas, J. Evaluation of antioxidant activity and flavonoid composition in differently preserved bee products. Czech J. Food Sci. 2016, 34, 133-142. [CrossRef]

13. Nayik, G.A.; Nanda, V. A chemometric approach to evaluate the phenolic compounds, antioxidant activity and mineral content of different unifloral honey types from Kashmir, India. LWT 2016, 74, 504-513. [CrossRef]

14. Cinkmanis, I.; Dimins, F.; Mikelsone, V. Influence of Lyophilization and convective type drying on antioxidant properties, total phenols and flavonoids in pollens. In Proceedings of the 11th Baltic Conference on Food Science and Technology "Food Science and Technology in a Changing World, Jelgava, Latvia, 27-28 April 2017; pp. 201-203.

15. Ozkan, K.; Sagcan, N.; Ozulku, G.; Sagdic, O.; Toker, O.S.; Muz, M.N. Bioactive and bioaccessibility characteristics of honeybee pollens collected from different regions of Turkey. J. Food Meas. Charact. 2017, 12, 581-587. [CrossRef]

16. Yang, Y.; Zhang, J.; Zhou, Q.; Wang, L.; Huang, W.; Wang, R. Effect of ultrasonic and ball-milling treatment on cell wall, nutrients, and antioxidant capacity of rose (Rosa rugosa) bee pollen, and identification of bioactive components. J. Sci. Food Agric. 2019, 99, 5350-5357. [CrossRef] [PubMed] 
17. Gorjanović, S.Ž.; Alvarez-Suarez, J.M.; Novaković, M.M.; Pastor, F.T.; Pezo, L.; Battino, M.; Sužnjević, D.Ž. Comparative analysis of antioxidant activity of honey of different floral sources using recently developed polarographic and various spectrophotometric assays. J. Food Compos. Anal. 2013, 30, 13-18. [CrossRef]

18. Khalil, I.; Moniruzzaman, M.; Boukraâ, L.; Benhanifia, M.; Islam, A.; Islam, N.; Sulaiman, S.A.; Gan, S.H. Physicochemical and Antioxidant Properties of Algerian Honey. Molecules 2012, 17, 11199-11215. [CrossRef]

19. Hmidani, A.; Bouhlali, E.D.T.; Khouya, T.; Ramchoun, M.; Filali-Zegzouti, Y.; Benlyas, M.; Alem, C. Effect of extraction methods on antioxidant and anticoagulant activities of Thymus atlanticus aerial part. Sci. Afr. 2019, 5, 5. [CrossRef]

20. Dailey, A.; Vuong, Q.V. Effect of extraction solvents on recovery of bioactive compounds and antioxidant properties from macadamia (Macadamia tetraphylla) skin waste. Cogent Food Agric. 2015, 1, 1115646. [CrossRef]

21. Azwanida, A. A Review on the Extraction Methods Use in Medicinal Plants, Principle, Strength and Limitation. Med. Aromat. Plants 2015, 04, 04. [CrossRef]

22. Khadra, L.; Kamel, M.; Hamama, B.; Ibrahim, D.; Daoud, H. Chemical composition, antioxidant and antimicrobial activities of algerian bee pollen (inula viscosa) methanolic extract. Int. J. Res. Pharm. Chem. 2019, 9, 9. [CrossRef]

23. De-Melo, A.A.M.; Estevinho, M.L.M.F.; Sattler, J.A.G.; Souza, B.R.; Freitas, A.D.S.; Barth, O.M.; de Almeida-Muradian, L.B. Effect of processing conditions on characteristics of dehydrated bee-pollen and correlation between quality parameters. LWT 2016, 65, 808-815. [CrossRef]

24. Alimoglu, G.; Guzelmeric, E.; Yuksel, P.I.; Celik, C.; Deniz, I.; Yesilada, E. Monofloral and polyfloral bee pollens: Comparative evaluation of their phenolics and bioactivity profiles. LWT 2021, 142, 110973. [CrossRef]

25. Pascoal, A.; Rodrigues, S.; Teixeira, A.; Feás, X.; Estevinho, L.M. Biological activities of commercial bee pollens: Antimicrobial, antimutagenic, antioxidant and anti-inflammatory. Food Chem. Toxicol. 2014, 63, 233-239. [CrossRef]

26. Morais, M.; Moreira, L.; Feás, X.; Estevinho, L.M. Honeybee-collected pollen from five Portuguese Natural Parks: Palynological origin, phenolic content, antioxidant properties and antimicrobial activity. Food Chem. Toxicol. 2011, 49, 1096-1101. [CrossRef]

27. Leja, M.; Mareczek, A.; Wyżgolik, G.; Klepacz-Baniak, J.; Czekońska, K. Antioxidative properties of bee pollen in selected plant species. Food Chem. 2007, 100, 237-240. [CrossRef]

28. Mărghitaş, L.A.; Stanciu, O.G.; Dezmirean, D.S.; Bobis, O.; Popescu, O.; Bogdanov, S.; Campos, M.G. In vitro antioxidant capacity of honeybee-collected pollen of selected floral origin harvested from Romania. Food Chem. 2009, 115, 878-883. [CrossRef]

29. Thakur, M.; Nanda, V. Screening of Indian bee pollen based on antioxidant properties and polyphenolic composition using UHPLC-DAD-MS/MS: A multivariate analysis and ANN based approach. Food Res. Int. 2021, 140, 110041. [CrossRef] [PubMed]

30. De-Melo, A.A.M.; Estevinho, L.M.; Moreira, M.M.; Delerue-Matos, C.; Freitas, A.D.S.D.; Barth, O.M.; de Almeida-Muradian, L.B. A multivariate approach based on physicochemical parameters and biological potential for the botanical and geographical discrimination of Brazilian bee pollen. Food Biosci. 2018, 25, 91-110. [CrossRef]

31. Kaškonienè, V.; Adaškevičiūtè, V.; Kaškonas, P.; Mickienè, R.; Maruška, A. Antimicrobial and antioxidant activities of natural and fermented bee pollen. Food Biosci. 2020, 34, 100532. [CrossRef]

32. Omar, W.A.W.; Azhar, N.A.; Fadzilah, N.H.; Kamal, N.N.S.N.M. Bee pollen extract of Malaysian stingless bee enhances the effect of cisplatin on breast cancer cell lines. Asian Pac. J. Trop. Biomed. 2016, 6, 265-269. [CrossRef]

33. Khongkarat, P.; Ramadhan, R.; Phuwapraisirisan, P.; Chanchao, C. Safflospermidines from the bee pollen of Helianthus annuus L. exhibit a higher in vitro antityrosinase activity than kojic acid. Heliyon 2020, 6, e03638. [CrossRef] [PubMed]

34. Zhang, H.; Wang, X.; Wang, K.; Li, C. Antioxidant and Tyrosinase Inhibitory Properties of Aqueous Ethanol Extracts from Monofloral Bee Pollen. J. Apic. Sci. 2015, 59, 119-128. [CrossRef]

35. Hemmami, H.; Ben Seghir, B.; Ben Ali, M.; Rebiai, A.; Zeghoud, S.; Brahmia, F. Phenolic profile and antioxidant activity of bee pollen extracts from different regions of Algeria. Ovidius Univ. Ann. Chem. 2020, 31, 93-98. [CrossRef]

36. Izuta, H.; Narahara, Y.; Shimazawa, M.; Mishima, S.; Kondo, S.-I.; Hara, H. 1,1-Diphenyl-2-picrylhydrazyl Radical Scavenging Activity of Bee Products and Their Constituents Determined by ESR. Biol. Pharm. Bull. 2009, 32, 1947-1951. [CrossRef] [PubMed]

37. Zuluaga-Domínguez, C.; Serrato-Bermudez, J.; Quicazan, M.; Zuluaga, C.; Serrato, J. Influence of drying-related operations on microbiological, structural and physicochemical aspects for processing of bee-pollen. Eng. Agric. Environ. Food 2018, 11, 57-64. [CrossRef]

38. Keskin, M.; Özkök, A. Effects of drying techniques on chemical composition and volatile constituents of bee pollen. Czech J. Food Sci. 2020, 38, 203-208. [CrossRef]

39. Vasconcelos, M.R.D.S.; Duarte, A.; Gomes, E.P.; Da Silva, S.C.; López, A.M.Q. Physicochemical composition and antioxidant potential of bee pollen from different botanical sources in Alagoas, Brazil. Ciência Agrotecnol. 2017, 41, 447-458. [CrossRef]

40. Predictive mathematical modeling for EC50 calculation of antioxidant activity and antibacterial ability of Thai bee products. $J$. Appl. Pharm. Sci. 2017, 7, 122-133. [CrossRef]

41. Cosmulescu, S.; Trandafir, I.; Nour, V. Chemical Composition and Antioxidant Activity of Walnut Pollen Samples. Not. Bot. Horti Agrobot. Cluj-Napoca 2015, 43, 361-365. [CrossRef]

42. Bridi, R.; Atala, E.; Pizarro, P.N.; Montenegro, G. Honeybee Pollen Load: Phenolic Composition and Antimicrobial Activity and Antioxidant Capacity. J. Nat. Prod. 2019, 82, 559-565. [CrossRef] [PubMed]

43. Lopes, A.J.O.; Vasconcelos, C.C.; Pereira, F.; Silva, R.H.M.; Queiroz, P.F.D.S.; Fernandes, C.V.; Garcia, J.B.S.; Ramos, R.M.; Da Rocha, C.Q.; Lima, S.T.D.J.R.M.; et al. Anti-Inflammatory and Antinociceptive Activity of Pollen Extract Collected by Stingless Bee Melipona fasciculata. Int. J. Mol. Sci. 2019, 20, 4512. [CrossRef] [PubMed] 
44. Lopes, A.J.O.; Vasconcelos, C.C.; Garcia, J.B.S.; Pinheiro, M.S.D.; Pereira, F.A.N.; Camelo, D.D.S.; De Morais, S.V.; Freitas, J.R.B.; Da Rocha, C.Q.; Ribeiro, M.N.D.S.; et al. Anti-Inflammatory and Antioxidant Activity of Pollen Extract Collected by Scaptotrigona affinis postica: In silico, in vitro, and in vivo Studies. Antioxidants 2020, 9, 103. [CrossRef] [PubMed]

45. Futui, W.; Thongwai, N. Antimicrobial and Antioxidant Activities, Total Phenolic and Flavonoid Contents of Bee Pollen Crude Extracts. Int. J. Biosci. Biochem. Bioinform. 2020, 10, 42-48. [CrossRef]

46. Nurdianah, H.F.; Firdaus, A.A.H.; Azam, O.E.; Wan Adnan, W.O. Antioxidant activity of bee pollen ethanolic extracts from Malaysian stingless bee measured using DPPH-HPLC assay. Int. Food Res. J. 2016, 23, 403-405.

47. Fatrcová-Šramková, K.; Nôžková, J.; Kačániová, M.; Máriássyová, M.; Rovná, K.; Stricik, M. Antioxidant and antimicrobial properties of monofloral bee pollen. J. Environ. Sci. Health Part B 2013, 48, 133-138. [CrossRef] [PubMed]

48. Sun, L.; Guo, Y.; Zhang, Y.; Zhuang, Y. Antioxidant and Anti-tyrosinase Activities of Phenolic Extracts from Rape Bee Pollen and Inhibitory Melanogenesis by cAMP/MITF/TYR Pathway in B16 Mouse Melanoma Cells. Front. Pharmacol. 2017, 8, 1-9. [CrossRef]

49. Su, J.; Yang, X.; Lu, Q.; Liu, R. Antioxidant and anti-tyrosinase activities of bee pollen and identification of active components. J. Apic. Res. 2021, 60, 297-307. [CrossRef]

50. Uçar, M.; Barlak, Y.; Deger, O. Antioxidant properties of dmso and water extracts of turkish bee pollen. World J. Pharm. Pharm. Sci. 2017, 6647, 154-163. [CrossRef]

51. Oroian, M.; Ursachi, F.; Dranca, F. Ultrasound-Assisted Extraction of Polyphenols from Crude Pollen. Antioxidants 2020, 9 , 322 [CrossRef]

52. Barbieri, D.; Gabriele, M.; Summa, M.; Colosimo, R.; Leonardi, D.; Domenici, V.; Pucci, L. Antioxidant, Nutraceutical Properties, and Fluorescence Spectral Profiles of Bee Pollen Samples from Different Botanical Origins. Antioxidants 2020, 9, 1001. [CrossRef] [PubMed]

53. Shen, Z.; Geng, Q.; Huang, H.; Yao, H.; Du, T.; Chen, L.; Wu, Z.; Miao, X.; Shi, P. Antioxidative and Cardioprotective Effects of Schisandra chinensis Bee Pollen Extract on Isoprenaline-Induced Myocardial Infarction in Rats. Molecules 2019, $24,1090$. [CrossRef] [PubMed]

54. Saral, Ö.; Yildiz, O.; Aliyazicioğlu, R.; Yuluğ, E.; Canpolat, S.; Öztürk, F.; Kolayli, S. Apitherapy products enhance the recovery of CCL4-induced hepatic damages in rats. Turk. J. Med. Sci. 2016, 46, 194-202. [CrossRef] [PubMed]

55. Pérez-Pérez, E.M.; Vit, P.; Rivas, E.; Sciortino, R.; Sosa, A.; Tejada, D.; Rodríguez-Malaver, A.J. Antioxidant activity of four color fractions of bee pollen from Mérida, Venezuela. Arch. Latinoam. Nutr. 2012, 62, 375-380.

56. Daudu, O.M. Bee Pollen Extracts as Potential Antioxidants and Inhibitors of $\alpha$-Amylase and $\alpha$-Glucosidase Enzymes In Vitro Assessment. J. Apic. Sci. 2019, 63, 315-325. [CrossRef]

57. Stanciu, O.G.; Dezmirean, D.S.; Campos, M.G. Bee Pollen in Transylvania (Romania): Palynological Characterization and ORACFL Values of Lipophilic and Hydrophilic Extracts of Monofloral Pollen Pellets. J. Agric. Sci. Technol. A 2016, 6, 18-37. [CrossRef]

58. Mayda, N.; Özkök, A.; Bayram, N.E.; Gerçek, Y.C.; Sorkun, K. Bee bread and bee pollen of different plant sources: Determination of phenolic content, antioxidant activity, fatty acid and element profiles. J. Food Meas. Charact. 2020, 14, 1795-1809. [CrossRef]

59. Anjos, O.; Fernandes, R.; Cardoso, S.M.; Delgado, T.; Farinha, N.; Paula, V.; Estevinho, L.M.; Carpes, S.T. Bee pollen as a natural antioxidant source to prevent lipid oxidation in black pudding. LWT 2019, 111, 869-875. [CrossRef]

60. Almeida, J.D.F.; dos Reis, A.S.; Heldt, L.F.S.; Pereira, D.; Bianchin, M.; de Moura, C.; Plata-Oviedo, M.V.; Haminiuk, C.; Ribeiro, I.S.; Luz, C.F.P.; et al. Lyophilized bee pollen extract: A natural antioxidant source to prevent lipid oxidation in refrigerated sausages. LWT 2017, 76, 299-305. [CrossRef]

61. Fatrcová-Šramková, K.; Nôžková, J.; Máriássyová, M.; Kačániová, M. Biologically active antimicrobial and antioxidant substances in theHelianthus annuusL. bee pollen. J. Environ. Sci. Health Part B 2016, 51, 176-181. [CrossRef]

62. Mosić, M.; Trifković, J.; Vovk, I.; Gašić, U.; Tešić, Ž.; Šikoparija, B.; Milojković-Opsenica, D. Phenolic Composition Influences the Health-Promoting Potential of Bee-Pollen. Biomolecules 2019, 9, 783. [CrossRef] [PubMed]

63. El Ghouizi, A.; El Menyiy, N.; Falcão, S.I.; Vilas-Boas, M.; Lyoussi, B. Chemical composition, antioxidant activity, and diuretic effect of Moroccan fresh bee pollen in rats. Veter. World 2020, 13, 1251-1261. [CrossRef] [PubMed]

64. Rebiai, A.; Lane, T. Chemical composition and antioxidant activity of Apis mellifera bee pollen from Northwest Algeria. J. Fundam. Appl. Sci. 2012, 4, 26-35. [CrossRef]

65. Araújo, J.S.; Chambó, E.D.; Costa, M.A.P.D.C.; Da Silva, S.M.P.C.; De Carvalho, C.A.L.; Estevinho, L.M. Chemical Composition and Biological Activities of Mono- and Heterofloral Bee Pollen of Different Geographical Origins. Int. J. Mol. Sci. 2017, 18, 921. [CrossRef]

66. Bárbara, M.S.; Machado, C.S.; Sodré, G.D.S.; Dias, L.G.; Estevinho, L.M.; De Carvalho, C.A.L. Microbiological Assessment, Nutritional Characterization and Phenolic Compounds of Bee Pollen from Mellipona mandacaia Smith, 1983. Molecules 2015, 20, 12525-12544. [CrossRef]

67. Carpes, S.T. Chemical composition and free radical scavenging activity of Apis mellifera bee pollen from Southern Brazil. Braz. J. Food Technol. 2009, 12, 220-229. [CrossRef]

68. Sartini, S.; Djide, M.N.; Nainu, F. Correlation Phenolic Concentration to Antioxidant and Antibacterial Activities of Several Ethanolic extracts from Indonesia. J. Phys. Conf. Ser. 2019, 1341, 072009. [CrossRef] 
69. Özcan, M.M.; Aljuhaimi, F.; Babiker, E.E.; Uslu, N.; Ceylan, D.A.; Ghafoor, K.; Özcan, M.M.; Dursun, N.; Ahmed, I.M.; Jamiu, F.G.; et al. Determination of Antioxidant Activity, Phenolic Compound, Mineral Contents and Fatty Acid Compositions of Bee Pollen Grains Collected from Different Locations. J. Apic. Sci. 2019, 63, 69-79. [CrossRef]

70. Zuluaga-Dominguez, C.M.; Quicazan, M. Effect of Fermentation on Structural Characteristics and Bioactive Compounds of Bee-Pollen Based Food. J. Apic. Sci. 2019, 63, 209-222. [CrossRef]

71. Duran, A.; Quicazan, M.; Zuluaga-Dominguez, C. Effect of Solar Drying Process on Bioactive Compounds and Antioxidant Activity in Vitro of High Andean Region Bee Pollen. Chem. Eng. Trans. 2019, 75, 91-96. [CrossRef]

72. Aleksieva, K.I.; Mladenova, R.B.; Solakov, N.Y.; Loginovska, K.K. EPR analysis of free radical components and antioxidant activity of bee pollen before and after gamma-irradiation. J. Radioanal. Nucl. Chem. 2021, 327, 713-719. [CrossRef]

73. Atsalakis, E.; Chinou, I.; Makropoulou, M.; Karabournioti, S.; Graikou, K. Evaluation of Phenolic Compounds in Cistus creticus Bee Pollen from Greece. Antioxidant and Antimicrobial Properties. Nat. Prod. Commun. 2017, 12, 1813-1816. [CrossRef]

74. Saral, Ö.; Kiliçarslan, M.; Şahin, H.; Yildiz, O.; Dinçer, B. Evaluation of antioxidant activity of bee products of different bee races in Turkey. Turk. J. Veter. Anim. Sci. 2019, 43, 441-447. [CrossRef]

75. Al-Salem, H.S.; Al-Yousef, H.M.; Ashour, A.E.; Ahmed, A.F.; Amina, M.; Issa, I.S.; Bhat, R.S. Antioxidant and hepatorenal protective effects of bee pollen fractions against propionic acid-induced autistic feature in rats. Food Sci. Nutr. 2020, 8, 5114-5127. [CrossRef] [PubMed]

76. Gabriele, M.; Parri, E.; Felicioli, A.; Sagona, S.; Pozzo, L.; Biondi, C.; Domenici, V.; Pucci, L. Phytochemical composition and antioxidant activity of Tuscan bee pollen of different botanic origins. Ital. J. Food Sci. 2015, 27, $248-259$.

77. Yıldız, O.; Can, Z.; Saral, O.; Yuluğ, E.; Oztürk, F.; Aliyazıcıŏ̆lu, R.; Canpolat, S.; Kolaylı, S. Hepatoprotective Potential of Chestnut Bee Pollen on Carbon Tetrachloride-Induced Hepatic Damages in Rats. Evid. Based Complement. Altern. Med. 2013, 2013, 1-9. [CrossRef] [PubMed]

78. Rocchetti, G.; Castiglioni, S.; Maldarizzi, G.; Carloni, P.; Lucini, L. UHPLC-ESI-QTOF-MS phenolic profiling and antioxidant capacity of bee pollen from different botanical origin. Int. J. Food Sci. Technol. 2018, 54, 335-346. [CrossRef]

79. Yan, S.; Li, Q.; Xue, X.; Wang, K.; Zhao, L.; Wu, L. Analysis of improved nutritional composition of bee pollen (Brassica campestris L.) after different fermentation treatments. Int. J. Food Sci. Technol. 2019, 54, 2169-2181. [CrossRef]

80. Rebiai, A.; Lanez, T. A Facile Electrochemical Analysis to Determine Antioxidant Activity of Bee Pollen. Int. Lett. Chem. Phys. Astron. 2013, 14, 31-38. [CrossRef]

81. Cheng, N.; Chen, S.; Liu, X.; Zhao, H.; Cao, W. Impact of SchisandraChinensis Bee Pollen on Nonalcoholic Fatty Liver Disease and Gut Microbiota in HighFat Diet Induced Obese Mice. Nutrients 2019, 11, 346. [CrossRef]

82. Muñoz, E.; Velásquez, P.; Rodriguez, K.; Montenegro, G.; Giordano, A. Influence of Brassica campestris and Galega officinalis on Antioxidant Activity of Bee Pollen. Rev. Bras. Farm. 2020, 30, 444-449. [CrossRef]

83. Yesiltas, B.; Capanoglu, E.; Frratligil-Durmuş, E.; Sunay, A.E.; Samanci, T.; Boyacioglu, D. Investigating the in-vitro bioaccessibility of propolis and pollen using a simulated gastrointestinal digestion System. J. Apic. Res. 2014, 53, 101-108. [CrossRef]

84. Mejías, E.; Montenegro, G. The Antioxidant Activity of Chilean Honey and Bee Pollen Produced in the Llaima Volcano's Zones. J. Food Qual. 2012, 35, 315-322. [CrossRef]

85. Negri, G.; Teixeira, É.W.; Alves, M.L.T.M.F.; Moreti, A.C.D.C.C.; Otsuk, I.P.; Borguini, R.G.; Salatino, A. Hydroxycinnamic Acid Amide Derivatives, Phenolic Compounds and Antioxidant Activities of Extracts of Pollen Samples from Southeast Brazil. J. Agric. Food Chem. 2011, 59, 5516-5522. [CrossRef]

86. Campos, M.G.; Webby, R.F.; Markham, K.R.; Mitchell, K.A.; Da Cunha, A.P. Age-Induced Diminution of Free Radical Scavenging Capacity in Bee Pollens and the Contribution of Constituent Flavonoids. J. Agric. Food Chem. 2003, 51, 742-745. [CrossRef]

87. Ulusoy, E.; Kolayli, S. Phenolic Composition and Antioxidant Properties of Anzer Bee Pollen. J. Food Biochem. $2013,38,73-82$. [CrossRef]

88. Mohdaly, A.A.; Mahmoud, A.A.; Roby, M.; Smetanska, I.; Ramadan, M.F. Phenolic Extract from Propolis and Bee Pollen: Composition, Antioxidant and Antibacterial Activities. J. Food Biochem. 2015, 39, 538-547. [CrossRef]

89. De-Melo, A.A.M.; Estevinho, L.M.; Moreira, M.M.; Delerue-Matos, C.; Freitas, A.D.S.D.; Barth, O.M.; de Almeida-Muradian, L.B. Phenolic profile by HPLC-MS, biological potential, and nutritional value of a promising food: Monofloral bee pollen. J. Food Biochem. 2018, 42, e12536. [CrossRef]

90. Şahin, S.; Karkar, B. The antioxidant properties of the chestnut bee pollen extract and its preventive action against oxidatively induced damage in DNA bases. J. Food Biochem. 2019, 43, e12888. [CrossRef] [PubMed]

91. Belina-Aldemita, M.D.; Schreiner, M.; D'Amico, S. Characterization of phenolic compounds and antioxidative potential of pot-pollen produced by stingless bees (Tetragonula biroiFriese) from the Philippines. J. Food Biochem. 2020, 44, e13102. [CrossRef]

92. Zuluaga-Domínguez, C.; Castro-Mercado, L.; Quicazán, M.C. Effect of enzymatic hydrolysis on structural characteristics and bioactive composition of bee-pollen. J. Food Process. Preserv. 2019, 43, e13983. [CrossRef]

93. Bujang, J.S.; Zakaria, M.H.; Ramaiya, S.D. Chemical constituents and phytochemical properties of floral maize pollen. PLoS ONE 2021, 16, e0247327. [CrossRef]

94. Kaškonienè, V.; Kaškonas, P.; Maruška, A. Volatile compounds composition and antioxidant activity of bee pollen collected in Lithuania. Chem. Pap. 2015, 69, 291-299. [CrossRef]

95. Kaškonienè, V.; Katilevičiūte, A.; Kaškonas, P.; Maruska, A. The impact of solid-state fermentation on bee pollen phenolic compounds and radical scavenging capacity. Chem. Pap. 2018, 72, 2115-2120. [CrossRef] 
96. Khider, M.; Elbanna, K.; Mahmoud, A.; Owayss, A.A. Egyptian honeybee pollen as antimicrobial, antioxidant agents, and dietary food supplements. Food Sci. Biotechnol. 2013, 22, 1-9. [CrossRef]

97. Canale, A.; Benelli, G.; Castagna, A.; Sgherri, C.; Poli, P.; Serra, A.; Mele, M.; Ranieri, A.; Signorini, F.; Bientinesi, M.; et al. Microwave-Assisted Drying for the Conservation of Honeybee Pollen. Materials 2016, 9, 363. [CrossRef]

98. Freire, K.R.L.; Lins, A.C.S.; Dórea, M.C.; Santos, F.A.R.; Camara, C.A.; Silva, T.M.S. Palynological Origin, Phenolic Content, and Antioxidant Properties of Honeybee-Collected Pollen from Bahia, Brazil. Molecules 2012, 17, 1652-1664. [CrossRef]

99. Kim, S.B.; Jo, Y.H.; Liu, Q.; Ahn, J.H.; Hong, I.P.; Han, S.M.; Hwang, B.Y.; Lee, M.K. Optimization of Extraction Condition of Bee Pollen Using Response Surface Methodology: Correlation between Anti-Melanogenesis, Antioxidant Activity, and Phenolic Content. Molecules 2015, 20, 19764-19774. [CrossRef] [PubMed]

100. Zhang, Y.; Yang, F.; Jamali, M.A.; Peng, Z. Antioxidant Enzyme Activities and Lipid Oxidation in Rape (Brassica campestris L.) Bee Pollen Added to Salami during Processing. Molecules 2016, 21, 1439. [CrossRef]

101. Zhang, H.; Liu, R.; Lu, Q. Separation and Characterization of Phenolamines and Flavonoids from Rape Bee Pollen, and Comparison of Their Antioxidant Activities and Protective Effects against Oxidative Stress. Molecules 2020, 25, 1264. [CrossRef]

102. Castagna, A.; Benelli, G.; Conte, G.; Sgherri, C.; Signorini, F.; Nicolella, C.; Ranieri, A.; Canale, A. Drying Techniques and Storage: Do They Affect the Nutritional Value of Bee-Collected Pollen? Molecules 2020, 25, 4925. [CrossRef] [PubMed]

103. Oyarzún, J.E.; Andia, M.E.; Uribe, S.; Pizarro, P.N.; Núñez, G.; Montenegro, G.; Bridi, R. Honeybee Pollen Extracts Reduce Oxidative Stress and Steatosis in Hepatic Cells. Molecules 2021, 26, 6. [CrossRef] [PubMed]

104. Asmae, E.G.; Nawal, E.M.; Bakour, M.; Lyoussi, B. Moroccan Monofloral Bee Pollen: Botanical Origin, Physicochemical Characterization, and Antioxidant Activities. J. Food Qual. 2021, 2021, 1-10. [CrossRef]

105. Rodriguez-Gonzalez, I.; Ortega-Toro, R.; Diaz, C. Influence of microwave- and ultrasound-assisted extraction on bioactive compounds from pollen. Contemp. Eng. Sci. 2018, 11, 1669-1676. [CrossRef]

106. Velasquez, P.; Rodriguez, K.; Retamal, M.; Giordano, A.; Valenzuela, L.M.; Montenegro, G. Relation between composition, antioxidant and antibacterial activities and botanical origin of multi-floral bee pollen. J. Appl. Bot. Food Qual. 2017, 90, 306-314. [CrossRef]

107. Carpes, S.; De Alencar, S.; Cabral, I.; Oldoni, T.; Mourão, G.; Haminiuk, C.; Da Luz, C.; Masson, M.L. Polyphenols and palynological origin of bee pollen ofApis melliferaL. from Brazil. Characterization of polyphenols of bee pollen. CyTA J. Food 2013, 11, 150-161. [CrossRef]

108. Bárbara, M.F.S.; Moreira, M.M.; Machado, C.S.; Chambó, E.D.; Pascoal, A.; De Carvalho, C.A.L.; Sodré, G.D.S.; Delerue-Matos, C.; Estevinho, L.M. Storage methods, phenolic composition, and bioactive properties of Apis mellifera and Trigona spinipes pollen. $J$. Apic. Res. 2020, 60, 1-9. [CrossRef]

109. Carpes, S.T.; Begnini, R.; De Alencar, S.M.; Masson, M.L. Study of preparations of bee pollen extracts, antioxidant and antibacterial activity. Ciência Agrotecnol. 2007, 31, 1818-1825. [CrossRef]

110. Zou, Y.; Hu, J.; Huang, W.; Zhu, L.; Shao, M.; Dordoe, C.; Ahn, Y.-J.; Wang, D.; Zhao, Y.; Xiong, Y.; et al. The botanical origin and antioxidant, anti-BACE1 and antiproliferative properties of bee pollen from different regions of South Korea. BMC Complement. Med. Ther. 2020, 20, 236. [CrossRef]

111. Paradowska, K.; Zielińska, A.; Kuras, M.; Wawer, I. The composition of bee pollen color fractions evaluated by solid-state $1 \mathrm{H}$ and 13C NMR: Their macroelement content and antioxidant properties. J. Apic. Res. 2017, 56, 523-532. [CrossRef]

112. Yildiz, O.; Karahalil, F.Y.; Can, Z.; Sahin, H.; Kolayli, S. Total monoamine oxidase (MAO) inhibition by chestnut honey, pollen and propolis. J. Enzym. Inhib. Med. Chem. 2014, 29, 690-694. [CrossRef] [PubMed]

113. Silva, T.M.; Camara, C.; Lins, A.C.; Agra, M.D.F.; Silva, E.M.; Reis, I.T.; Freitas, B. Chemical composition, botanical evaluation and screening of radical scavenging activity of collected pollen by the stingless bees Melipona rufiventris (Uruçu-amarela). An. Acad. Bras. Ciências 2009, 81, 173-178. [CrossRef] [PubMed]

114. Dai, Y.; Ding, Z.; Lei, Y.; Yufen, B. Polyphenol Content in Chinese Bee Products and Their Antioxidant Activity. Asian J. Chem. 2013, 25, 8019-8021. [CrossRef]

115. Amalia, E.; Diantini, A.; Subarnas, A. Water-soluble propolis and bee pollen of Trigona spp. from South Sulawesi Indonesia induce apoptosis in the human breast cancer MCF-7 cell line. Oncol. Lett. 2020, 20, 1. [CrossRef] [PubMed]

116. Liberato, M.D.C.T.C.; De Morais, S.M.; Siqueira, S.M.C.; De Menezes, J.E.S.A.; Ramos, D.N.; Machado, L.K.A.; Magalhães, I.L. Phenolic Content and Antioxidant and Antiacetylcholinesterase Properties of Honeys from Different Floral Origins. J. Med. Food 2011, 14, 658-663. [CrossRef]

117. Karabagias, I.K.; Louppis, A.P.; Karabournioti, S.; Kontakos, S.; Papastephanou, C.; Kontominas, M.G. Characterization and geographical discrimination of commercial Citrus spp. honeys produced in different Mediterranean countries based on minerals, volatile compounds and physicochemical parameters, using chemometrics. Food Chem. 2017, 217, 445-455. [CrossRef] [PubMed]

118. Zhang, Q.-W.; Lin, L.-G.; Ye, W.-C. Techniques for extraction and isolation of natural products: A comprehensive review. Chin. Med. 2018, 13, 1-26. [CrossRef] [PubMed]

119. Sánchez-Rangel, J.C.; Benavides, J.; Heredia, J.B.; Cisneros-Zevallos, L.; Jacobo-Velázquez, D.A. The Folin-Ciocalteu assay revisited: Improvement of its specificity for total phenolic content determination. Anal. Methods 2013, 5, 5990-5999. [CrossRef] 